FACULDADE DE FILOSOFIA, LETRAS E CIÊNCIAS HUMANAS

DEPARTAMENTO DE HISTÓRIA

PROGRAMA DE PÓS-GRADUAÇÃO EM HISTÓRIA SOCIAL

Kleber Antonio de Oliveira Amancio

À procura da liberdade moral: a vida cotidiana dos

ex-escravos e de seus descendentes no pósabolição na Campinas das primeiras décadas do século XX.

São Paulo

2010 
UNIVERSIDADE DE SÃO PAULO

FACULDADE DE FILOSOFIA, LETRAS E CIÊNCIAS HUMANAS

DEPARTAMENTO DE HISTÓRIA

PROGRAMA DE PÓS-GRADUAÇÃO EM HISTÓRIA SOCIAL

\section{À procura da liberdade moral: a vida cotidiana dos ex-escravos e de seus descendentes no pós- abolição na Campinas das primeiras décadas do século XX.}

Kleber Antonio de Oliveira Amancio

Dissertação apresentada ao Departamento de História da Faculdade de Filosofia, Letras e Ciências Humanas da Universidade de São Paulo como parte dos requisitos para obtenção do título de mestre em História.

Orientadora: Profa. Dra. Maria Odila Leite da Silva Dias

São Paulo

2010 
Aos meus pais Benedito e

Nivalda e ao meu irmão

Vitor Hugo. 


\section{AGRADECIMENTOS}

Vão aqui alguns agradecimentos às pessoas que tornaram, de uma maneira ou de outra, a escrita dessa dissertação viável é aprazível. Primeiramente é míster registrar minha ilimitada gratidão a professora Maria Odila Leite da Silva Dias, minha orientadora, que confiou no meu trabalho desde a seleção, quando ainda se quer nos conhecíamos pessoalmente e eu só tinha algumas idéias. Ela é um tipo de intelectual raro; ágil de pensamento, figura humana definitivamente irresistível, uma scholar ausente de pedantismo.

Agradeço também a minha família, meus pais e meu irmão que nunca sempre me animaram e nunca duvidaram de minhas capacidades, apesar de todas as dificuldades, nem quando eu mesmo não acreditava.

Aos amigos que fiz na graduação, e já vão sete anos: Breno, Caio, Guilherme, Lis, Lizandra, Pavani, Rafa, Renata e Wilson. A época de UNICAMP passou, mas suas amizades não.

Aos amigos que contribuíram com sua leitura e puderam encontrar problemas que minha leitura viciada já não mais alcançava; Gustavo, Tais, Leca, Raquel e Isa.

Aos arquivistas do CMU/UNICAMP cujo trabalho foi indispensável para a realização dessa pesquisa e a Fapesp, que me concedeu uma bolsa durante a segunda metade da pesquisa, o que me permitiu, entre outras coisas, poder participar de congressos e me dedicar integralmente ao texto. 


\section{RESUMO}

O presente estudo disserta sobre a vida cotidiana dos ex-escravos, ex-libertos e seus descendentes no Brasil pós-emancipação. Tem por escopo atingir, ainda que parcialmente, o que teria sido para esses sujeitos sua experiência dentro deste contexto social de profunda transformação. O recorte espacial é a cidade de Campinas, sobretudo sua porção urbana. Cidade essa que, por ser importante pólo econômico no século XIX, adquiriu uma população escrava considerável. Quanto à temporalidade, o texto abrange três décadas; a começar pelo grande evento (a abolição formal do cativeiro) e a findar nas primeiras duas décadas do século XX. Alcançar os conflitos existentes nessa sociedade e, ao mesmo tempo, entender os referenciais culturais dos agentes envolvidos, são as maiores ambições desse texto.

\section{ABSTRACT}

This work aims to study the routine of ex-slaves, ex-freedmen and their descendants in Brazilian's society of post-emancipation. My intent on researching this question, even though partially, is what would have been for these historical subjects mentioned their experience within this context of such deep social transformation. The spatial area is the city of Campinas, especially its urban part. This area, in its turn, was an important economic centre in the nineteenth century and consequently had a considerable population of slaves. Concerning about the temporality, the text covers three decades, starting with the big event (the formal abolition of slavery system) and ending in the first two decades of the twentieth century. To understand the conflicts in this society and, at the same time, knowing about the cultural references of the agents who were involved with are the greatest ambitions of this text.

Palavras-chave: Pós-emancipação - Trabalho Informal - História Social - Campinas história Urbana 


\section{SUMÁRIO}

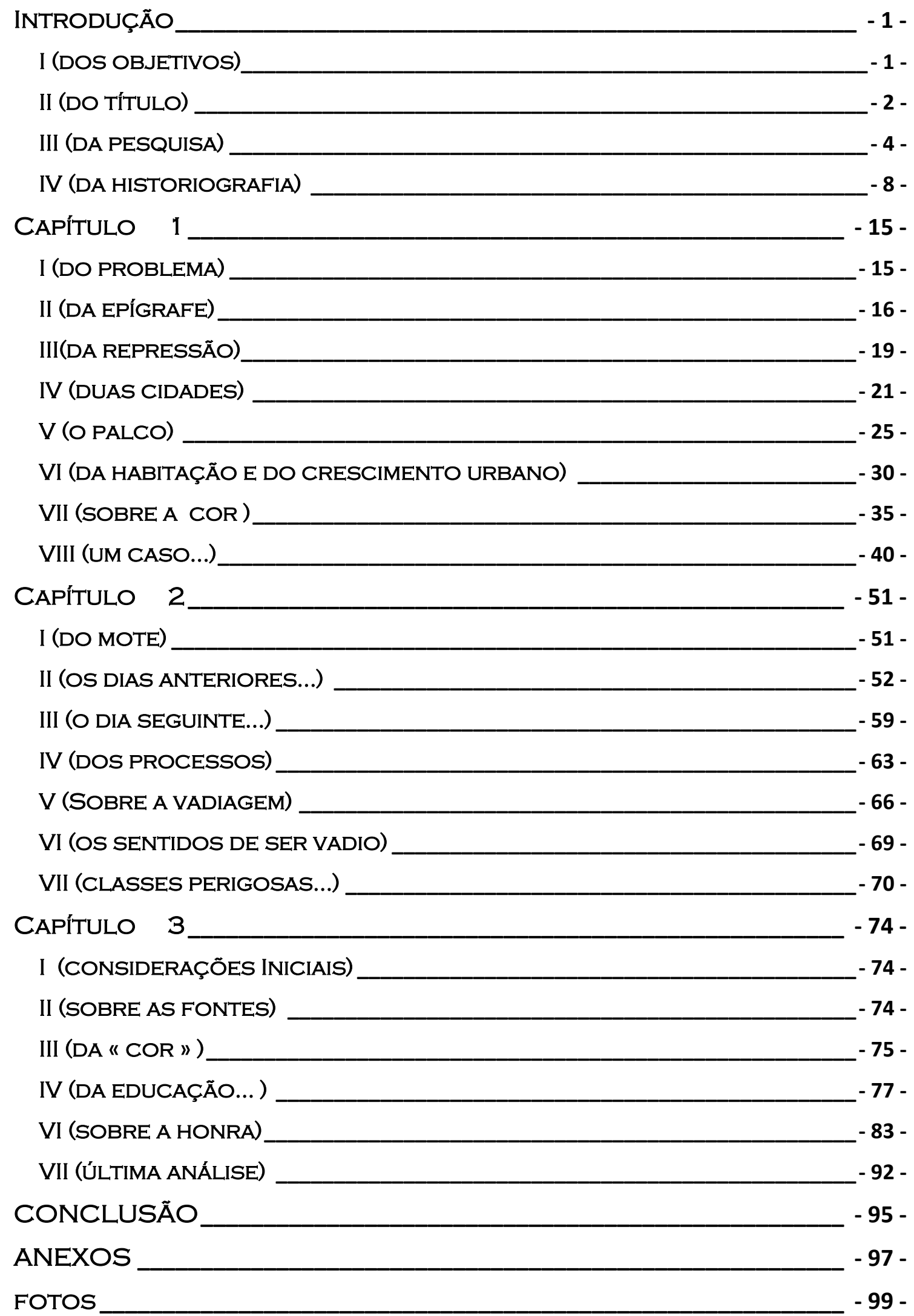


FONTES - 103 BIBLIOGRAFIA - 104 - 


\section{INTRODUÇÃO}

Eu gosto de catar o mínimo e o escondido. Onde ninguém mete o nariz, aí entra o meu, com a curiosidade estreita e aguda que descobre o encoberto. [...] A vantagem dos míopes é enxergar onde as grandes vistas não pegam. [Machado de Assis].

\section{I (DOS OBJETIVOS)}

Esta dissertação se pretende um estudo da vida cotidiana e das maneiras de pensar dos ex-escravos, libertos e seus descendentes em Campinas no pós-emancipação. O recorte cronológico compreende o final (formal) do cativeiro, assim como as três décadas imediatas a esse episódio. Meu propósito é desvendar como essas personagens viviam, a partir de uma análise das coisas banais; entender não apenas como pensavam (por meio de indícios), mas como interpretavam o mundo a sua volta. Mais do que refletir sobre os efeitos da abolição nesse estremecido mundo interessa, especialmente, saber os impactos que esse acontecimento teve na vida dos protagonistas dessa dissertação.

Delimitei o presente estudo às pessoas pobres, posto que a respeito dos ditos "homens de cor" muito já fosse dito e não se pode afirmar o mesmo a respeito daqueles que não conheceram a sorte de ascender socialmente, sobre estes ainda governa o silêncio. ${ }^{1}$ A fim de cumprir tal percurso minha abordagem ocupar-se-á das cousas

\footnotetext{
${ }^{1}$ Refiro-me, neste caso, a bibliografia que se ocupa do pós-emancipação em São Paulo. Literatura essa que costuma (ou costumava até pouco tempo) seccionar os negros paulistas em duas categorias (que por sinal entendiam-se um tanto quanto desconexas): a dos "homens de cor", que são aqueles que acenderam socialmente (mas não necessariamente alcançaram solidez econômica) e a "plebe negra", que é entendida como a somatória dos marginalizados e desqualificados sociais e que justamente por isso tiveram pouco poder de "reação" frente as dificuldades que lhes era imposta. Vide, por exemplo: BASTIDE, Roger. A Imprensa Negra no Estado de São Paulo. In: Estudos Afro-brasileiros. São Paulo: Perspectiva, 1973; DE QUEIRÓZ, M. I. P. Coletividades negras. Ascensão sócio-econômica dos negros no Brasil e em São Paulo. Ciência e Cultura, São Paulo, v. 29, nº, jun.1977; DOMINGUES, Petrônio. Uma história não contada: negro, racismo e branqueamento em São Paulo no pós-abolição. São Paulo: Editora SENAC, 2004 e FERRARA, M. N. A Imprensa Negra Paulista (1915-1963). 1981. 205fls. Dissertação (Mestrado em Antropologia), FFLCH, USP: 1981.
} 
miúdas, do rasteiro e do ordinário. É uma história que flerta com a microstoria, a história social e a etnografia. ${ }^{2}$ Se pretende o restauro da história de pessoas comuns e suas estratégias de enfrentamento com a vida.

\section{II (DO TÍTULO)}

Diz-se que o título informa muito sobre um texto. Ele reduz, direciona, interpreta... Por isso me parece apropriado dar a conhecer ao leitor a razão que me levou a escolher esse e não outro. Essa pesquisa, como não raramente acontece, surgiu como desdobramento de outra. Naquela oportunidade estava enredado em entender uma categoria social sui generis - a dos ditos "jornalistas negros". ${ }^{3}$ Produzi uma micro-história a respeito de um grupo de colaboradores de uma folha sediada em Campinas. Seu título: O Getulino, orgam para defesa dos interesses dos homens pretos. ${ }^{4}$ Conhece o leitor esse periódico? Cuidemos que não, que é para eu poder lançar a semente da minha idéia.

Denunciar os problemas, que no seu respectivo entendimento enfrentavam, cotidianamente, seus irmãos em cor, era o escopo do semanário. Seu mote era a frase latina "ridendo castigat mores". 5 Vejamos como se apresentavam:

\footnotetext{
${ }^{2}$ Não necessariamente de uma maneira que os interlocutores dos respectivos campos aprovariam, mas que entendo proveitosa e pertinente.

${ }^{3}$ A respeito da Imprensa Negra paulista no pós-emancipação conferir AMANCIO, K. A. de O. "Pela penna e pela palavra": Um Estudo sobre racismo, relações raciais e Imprensa Negra na Campinas das Primeiras décadas do século XX Monografia de fim de curso (Bacharelado em História), IFCH, UNICAMP, Campinas, 2006; BASTIDE, Roger. Obra citada; FERRARA, M. N. Obra citada; MIRANDA, Rodrigo. Um caminho de suor e letras: a militância negra em Campinas e a construção de uma comunidade imaginada nas páginas do Getulino (Campinas, 1923-1926). Tese (Doutorado em História), IFCH, UNICAMP, 2005; OLIVEIRA, A. C. de. Quem é a "Gente Negra Nacional"? Frente Negra Brasileira e a Voz da Raça, 1933-1937. 2006. Tese (Doutorado em História), IFCH, UNICAMP, Campinas, 2006.

TÍEDE, Lívia Maria. Imprensa Negra e espaços de sociabilidade em São Paulo no início do século XX. Monografia de fim de curso (Bacharelado em História). IFCH, UNICAMP, Campinas, 2003.

${ }^{4}$ Mais adiante, no subtítulo, passa-se a usar o termo "homens de cor" em detrimento do termo "preto". Talvez indicando mudança de postura desse jornal.

${ }^{5}$ Esta máxima remete a comedia Dell arte italiana, foi criada pelo literato Jean de Santeuil (1630-1697), e numa tradução livre feita pelos próprios jornalistas pode ser entendida como "rindo, castigar os
} 
Ridendo castigat mores: eis a nossa divisa; rindo castigar os costumes.

É pois o nosso escopo, como já foi dito, trabalhar pelo bem geral, o que faremos com o possível humor e empenhando nossas forças a favor da raça pigmentada, que não obstante os seus reforços e o muito que tem conseguido, ainda se ressente de grades prejuízos derivados da quadra de nefanda memória, em que esteve sujeita ao martírio inenarrável da escravidão pelo motivo de não ser branca ou amarela.

Queremos a prosperidade da raça negra, lutaremos para que a inteligência do homem de cor seja aproveitada, e para que o seu caráter iluminado pela fulgurante luz da instrução seja outro fator da grandeza deste país tão belo que em tudo diz ser falado para um futuro invejável. ${ }^{6}$

A fim de resolver essa situação é que "pela pena e pela palavra" ambicionavam prover a valoração da gente de pele escura. Por outro lado afirmavam que deveria competir aos próprios negros tomarem à mão a direção de suas próprias vidas. Consentir que a luz da instrução os arrebatasse era um começo. Livrar-se das coisas vis o antídoto, renunciar aos vícios dos hábitos imorais (entenda-se consumo de álcool e a luxúria descomedida), deixarem de frequentar bailes onde tocassem as jazz-band ou imperasse a jogatina (por sinal proibida), era salutar. Entendiam que faltava ainda aos negros a conquista de outra liberdade, complementar àquela conquistada em 1888. Nas palavras de um de seus articulistas:

A liberdade física apareceu radiosa e fulgurante em 88 , mas falta ainda a liberdade moral e intelectual, que não se obtém assim tão facilmente como a física, porque elas dependem não da vontade, mas sim do conjunto de vontades que se reúnem tão intimamente para chegar ao ponto final, como se fosse um rio a lançar no mar. Quem pode precisar o momento deste fenômeno? ${ }^{7}$

costumes". Foi usada na roupa de arlequim de um famoso artista do teatro italiano no início do século XVI e fez tanto sucesso que acabou adotada como mote pela comédia italiana e a ópera cômica.

${ }^{6}$ GETULINO. Campinas, SP, ano I, $\mathrm{n}^{\circ} 1,29$ de jull. 1923.

7 “Cartas Fluminenses". Getulino. Campinas, SP, ano I, nº 6, 2 set.1923. 
Um programa a fim de moldar o comportamento dos "homens pretos" era, portanto, o que preenchia a maior parte do papel dessa folha. Comportar-se para serem aceitos e quiçá integração à vista.

Com isso em mente, entendi ser um problema válido investigar, a partir de fontes outras, como essas personagens, a quem os jornalistas queriam forjar uma nova moral, viam-se. O primeiro obstáculo reside no fato de que fontes produzidas diretamente por essas pessoas são raras, para não dizer inexistentes. Como então seria possível fazê-lo?

A solução que encontrei foi fazê-lo a partir de fontes produzidas por outrem. Escolhi para isso os processos judiciais.

\section{III (DA PESQUISA)}

Após, portanto, ter estudado $O$ Getulino, minha idéia foi a de investigar as pessoas negras pobres da Campinas pós-emancipação. Os processos judiciais me sugeriam, àquela altura, ser o caminho mais promissor para se chegar ao cotidiano dessas pessoas pobres.

Diria que é difícil ler-se um documento desse tipo sem se deparar com novas questões. Arquitetei a pesquisa a partir da sucessiva leitura de processos criminais de roubo, furto, homicídio, estupro, defloramento além dos de contravenção de vadiagem e embriaguez. O recorte temporal escolhido cobre o período de 1888 à 1918, posto que trinta anos é um intervalo suficientemente grande para perceber as mudanças ao longo do tempo. Ao menos para o tipo de mudanças que procuro perceber nessa pesquisa. Emergiam dos autos, à medida que avançava em meu propósito, às personagens 
protagonistas dessa dissertação. Pessoas que residiam e (ou) circulavam em Campinas, cujas histórias de vida, por ventura, foram registradas pela pena do escrivão.

Dirão os mais céticos, que não há meios de se chegar aos "atos" por meio dos autos. Há uma série de barreiras intransponíveis, que nos impede de fazê-lo. O discurso do réu nunca se apresenta de maneira direta e é sempre mediado pela pena do escrivão, que, por sinal, é treinado para registrar a fala de modo predeterminado. ${ }^{8}$ Logo, o material que ali se encontra é parte de uma construção jurídica baseada num modelo de culpa e noutro de inocência. Diante disso, trabalhar no nível das representações jurídicas é a única opção viável. Evidentemente, não compartilho dessa atitude. A interpretação das fontes, a viabilidade das provas e do uso da narrativa é o que resume o ofício do historiador, ao menos aquela história que recomendo e procuro praticar.

A carência de depoimentos que registraram condutas e maneiras das classes subalternas de outrora é entrave para os historiadores desde que eles passaram a praticar esse tipo de história. Há três ou quatro décadas o pensamento histórico (i.e, a crítica histórica produzida por historiadores), teve uma guinada considerável, de tal modo que hoje já não é possível acusar os historiadores (ou ao menos nem todos) de se ocuparem apenas das gestas dos reis. Os "movimentos de massa”, os excluídos e as minorias em geral passaram a importar. Enfim, interessam-se mais por quem construiu as sete portas de Tebas.

Mas como chegar a voz desses sujeitos e dizer algo de relevante sobre suas existências? Estudos tão qualificados e distintos como os de Maria Odila Leite da Silva Dias, sobre trabalhadoras negras na São Paulo do século XIX, ou de Carlo Ginzburg acerca de um moleiro do Friulli na idade média, fizeram essa mesma pergunta e nos

\footnotetext{
${ }^{8}$ Encontrei um processo em que o delegado disserta sobre isso, como formatar um depoimento. A confissão foi feita na oportunidade em que reclamava sobre quão difícil era transpor o depoimento de uma moça com problemas mentais e surge a revelação de que se geralmente ele já enfrentava sérios problemas para fazê-lo, isso potencializava no caso em questão.
} 
ensinam que, se não podemos escutar com nitidez o que diziam essas pessoas, por conta da porosidade dos filtros e mediações, é certo que podemos ouvir alguns ecos e captar seus anseios e estratégias de vida. ${ }^{9}$

O historiador olha para as fontes (e é isso que os autos são para nós aqui: fontes), de modo diferente do juiz. Quando da leitura de um processo não estou preocupado em saber se o réu Honorio Egydio, por exemplo, deveras roubou um porco de seu vizinho, mas sim de outros aspectos que me parecem mais reveladores. Atentemos a esse caso por um instante.

A denúncia se deu de maneira incomum, por meio de uma carta expedida ao subdelegado de sobrenome sugestivo - Victorino Proust. Transcrevo- a, para que possa o leitor acompanhar meu argumento com mais propriedade:

Cidadão Delegado de Polícia desta Comarca.

Ao subdelegado d. Santa Cruz

Levo ao vosso conhecimento que, em minha chácara, situada na freguesia de Santa Cruz, desta cidade, os pretos Honorio, Sebastião, Jeremias e sua mulher, a poucos dias empregados como trabalhadores de lavoura, e todos moradores em uma só casa, roubaram do colono Mazzucato José, empregado na mesma minha chácara, um porco, que mataram na tarde do dia 6 do corrente.

Tendo o administrador conhecimento do fato no dia seguinte, 7 , pela manhã foi a casa dos referidos pretos e lá ainda encontrou metade do dito porco roubado, e sendo interrogados os pretos pelo administrador, confessaram que foi o preto Honorio que matara o porco pertencente ao colono Mazzucato. São testemunhas: Alexandre Hirsch, Jeronymo e Francisco.

Peço-vos portanto providências no sentido de punir o culpado.

Saúde e Fraternidade

Ao cidadão Delegado de Policia desta Comarca

Campinas 8 de julho de 1893.

Elisario F[abreviação] C. Andrade. [?]"10

\footnotetext{
${ }^{9}$ CF. DIAS, M. O. L. da S. Quotidiano e Poder em São Paulo no século XIX. 2 ${ }^{\text {a }}$ ed. São Paulo: Brasiliense, 1995; GINZBURG, Carlo. O queijo e os vermes: o cotidiano e as idéias de um moleiro perseguido pela inquisição. $3^{\mathrm{a}}$ ed. São Paulo, Companhia das Letras, 2005.
} 
Através desse documento descobrimos, entre outras coisas, que esse grupo de "pretos" (adjetivo com disposição de substantivo que em poucas linhas é usado por quatro vezes) habita a mesma casa na referida fazenda, e há poucos dias. Notemos que a palavra utilizada é "grupo" e não família. Excetuando-se Jeremias e sua mulher, os demais aparentemente não possuem qualquer grau de parentesco. Isso indica que havia, ao menos nesta chácara, habitações coletivas. Ou ainda que esse grupo constituísse uma rede de sociabilidade.

Notemos ainda a maneira de proceder do dono da chácara. Quando o colono Mazzucato reclamou do furto de um porco, ele tomou para si a posição de investigar o caso. Mas não seria esse o caso de procurar a polícia? Afinal corria o ano de 1893 e como é sabido durante a década de 1880 os senhores se viram, diante do avanço do movimento abolicionista, obrigados a negociar com mais frequencia e mais adiante ruir o sistema escravista e junto com ele sua política paternalista. Não competia mais, portanto, ao proprietário, detentor dos meios de produção, advogar sobre essas querelas, mas sim ao poder público. E é o que o referido proprietário da chácara faz, porém, não antes de inquirir por sua conta e formar um "inquérito" para adiantar o trabalho da justiça para que se punisse o culpado, como sugere imperativamente.

Essas questões que aventei, como o leitor deve notar, pouco ou cousa alguma tem a ver com o que interessava ao juiz e aos envolvidos na peleja. É um depoimento hostil, mas que devido a seus propósitos nos fornece pistas que se prestam também aos objetivos dessa dissertação. Oferece informações que escapam involuntariamente, mas

\footnotetext{
${ }^{10}$ Seu nome encontra-se assinado em tinta azul, diferente da carta, escrita de preto. O desenho da letra difere muito. Logo temos a seguinte situação - ou a carta foi ditada pelo dono da fazenda a outrem, ou ele contratou alguém com familiaridade com as letras para redigir a carta dizendo-lhe apenas os motivos que o levavam a acusar esse grupo de pessoas, talvez um escrivão ou advogado, posto que ela é relativamente bem escrita e articulada, diferente da maioria das cartas que encontrei como anexo de algum processo.
} 
que são de fundamental importância para nos aproximar da atmosfera dessa sociedade que nos é estrangeira.

Dentre o universo relativamente grande de processos que pude analisar escolhi alguns poucos para a análise. Em parte porque são um tanto quanto sumários em sua maioria, mas também porque muitos deles são bastante parecidos. Assim sendo escolhi os que mais me ofereceram elementos para discutir os assuntos que me proponho.

\section{IV (DA HISTORIOGRAFIA)}

O episódio citado acima mostra que personagens como Honorio Hegydio foram tratadas com desapreço. Contrasta com o clima de euforia que se via nas ruas quando da comemoração do 13 de maio nos grandes centros urbanos do país. As classes dirigentes apostavam ser a imigração, sobretudo a européia, o combustível necessário para elevar o país e combater a tão discutida "falta de braços" no campo. Soma-se a isso que o Estado investiu numa política repressiva e cerceadora, viam nisso um meio de ter as "classes perigosas" sob controle; posteriormente, contudo, mas não com menor gravidade, foram essas personagens negligenciadas mais uma vez, dessa vez pela chamada literatura da "transição" do trabalho escravo para o livre. ${ }^{11}$

O termo "transição" acende certo desconforto conceitual. Atualmente (e já há algum tempo) seu uso constitui o postulado de que uma substituição eficaz, completa e ordenada de mão-de-obra e de sujeito histórico, a qual, por assim dizer, efetivou-se após 1888. Deixaram o palco os escravos, ingênuos e libertos - anômicos, pouco ou nada ambiciosos, desprovidos de vontade própria e de objetivos, incapazes de sobreviverem

\footnotetext{
${ }^{11}$ Silvia Hunold Lara faz uma crítica contundente a essa historiografia em artigo provocador, segundo essa autora: “(...) apoiada em explicações economicistas ou em dados demográficos, a literatura sobre a transição não conseguiu, até hoje, dar foros de cidadania a milhares de homens e mulheres de pele escura que constituíram suas vidas sob o signo da escravidão e, principalmente, de uma liberdade que, embora conquistada, nunca conseguiu ser completa. CF. LARA, S. H. Escravidão, Cidadania e História do Trabalho no Brasil. Projeto História, São Paulo, v.16, pp. 25-38, 1998.
} 
na sociedade de classes e competirem no mercado de trabalho com os imigrantes europeus (esses sim racionais e organizados).

A historiografia sobre o processo pós-emancipatório no Brasil (assim como nas Américas de modo geral) tem crescido bastante. Foi-se o tempo em que os estudos do pós-emancipação ignoravam os destinos das pessoas que viveram sob a sombra do cativeiro. O debate atual se ocupa de novas questões, embora, todas essas novas pesquisas invistam na investigação das relações entre os processos de emancipação escrava e o destino dessa população em suas antigas sociedades. ${ }^{12}$ Historiadores e cientistas sociais não se ocupam mais em denunciar o racismo, mas em pensar como exescravos, libertos e seus descendentes, locomoviam-se nessa sociedade apesar do preconceito e do racismo, e por quais mecanismos esses sujeitos passaram a serem vistos como iguais pelos outros e por si mesmos. ${ }^{13}$

Esse momento de mudança, entre uma coisa e outra, é espaço privilegiado para perceber continuidades e diferenças com relação às estratégias cotidianas de sobrevivência. ${ }^{14}$ Estudos circunscritos a aspectos mais gerais, relacionados à estruturação da economia e informados pela imagem cristalizada de que o negro fora vitima passiva do sistema escravista têm cedido espaço a uma historiografia inquieta por aventar as escolhas e as possibilidades de escolha que essa parcela da população

\footnotetext{
${ }^{12}$ RIOS, A. L. \& MATTOS, H. M. Memórias do Cativeiro: Família, trabalho e cidadania no pósabolição. Rio de Janeiro, Civilização Brasileira, 2005.

${ }^{13}$ Nas palavras de Robert Slenes: "É importante frisar que os novos estudos não amenizam nossa visão dos horrores da escravidão, nem procuram fazer isso. Apenas devolvem ao escravismo sua "historicidade" como sistemas construídos por agentes sociais múltiplos, entre eles senhores e escravos." CF: SLENES, R. Na Senzala uma flor: esperanças e recordações na formação da família escrava Brasil Sudeste, século XIX. Rio de Janeiro, Editora Nova Fronteira, 1999.

${ }^{14}$ Alguns trabalhos clássicos sobre o tema são: SCHWARCZ, L. K. M. Retrato em branco e negro: jornais, escravos e cidadãos em São Paulo no final do século XIX. São Paulo, Companhia das Letras, 1987; MATTOS, H. Ao Sul da História: lavradores pobres na crise do trabalho escravo. São Paulo: Brasiliense, 1987; MACHADO, M. H. P. T. Crime e escravidão: Trabalho, Luta, Resistência nas lavouras paulistas, 1830-1888. São Paulo: Editora Brasiliense, 1988; ABREU, M. C. "Meninas Perdidas": Os Populares e O Cotidiano do Amor No Rio de Janeiro da Bellè Epóque. Rio de Janeiro: Paz e Terra, 1989.
} 
tinha a seu alcance. Trabalhos os mais diversos, sobre diferentes regiões do país tem vencido os obstáculos para se trabalhar com essa temática. ${ }^{15}$

Verifica-se a ascensão de uma historiografia preocupada em entender a experiência dos trabalhadores e grupos socialmente marginalizados no Brasil, pautada por problemas que ultrapassavam a idéia mais geral da questão da constituição da classe e suas formas de luta. Essa geração de pesquisadores insere no debate a idéia de que havia uma pluralidade de sujeitos políticos na sociedade, lutando à sua maneira, de acordo com suas necessidades, escolhas e possibilidades para atingir objetivos que lhes eram de primeira ordem e cuidando de serem responsáveis por si. Os escravos, que antes eram vistos, caricaturalmente, ou como heróis da resistência ou sujeitos indefesos (que se trancafiavam nas senzalas a espera de um abolicionismo radical que os salvasse de sua anomia), doravante passaram a se percebidos como mais ativos e sutis do que se imaginava até então.

Até meados da década de 70, era mais ou menos consensual a idéia de que a situação dos negros era conseqüência mais ou menos direta da chamada "herança da escravidão". Os principais articuladores dessa vertente explicativa foram Gilberto Freyre e Frank Tannembaum. ${ }^{16}$

Apesar da inegável contribuição de Freyre, tendo em vista a riqueza de sua obra, há de se ressaltar que a conclusão de sua tese é a de que o convívio nas senzalas fora

\footnotetext{
${ }^{15}$ Vide, entre outros - MATTOS, H. M. "Laços de família e direitos no final da escravidão". In: ALENCASTRO, Luiz Felipe de (Org.) História da vida privada no Brasil. Vol 2. Império: a corte e a modernidade nacional. Coleção dirigida por Fernando Novais. São Paulo: Companhia das Letras, 1997; ANDREWS, G. R. Negros e Brancos em São Paulo: 1888 - 1988. Bauru, Edusc, 1998; FRAGA FRAGA FILHO, Walter. Encruzilhadas da liberdade: histórias de escravos e libertos na Bahia (18701910), Campinas, Editora da UNICAMP, 2007; MARTINS, R. L. M. Os caminhos da liberdade Abolicionista, escravos e senhores na Província do Espírito Santo (1884-1888). Campinas, Área de Publicações/Centro de Memória Unicamp, 2005; ALBUQUERQUE, W. R. de. Algazarra nas ruas: comemorações da independência na Bahia (1889-1923). Campinas: Editora da Unicamp, 1999; WEIMER, R. de A. Os nomes da liberdade: experiências de autonomia e práticas de nomeação em um município da serra rio-grandense nas duas últimas décadas do século XIX. Dissertação (Mestrado em História), UFRGS, Porto Alegre, 2007.

${ }^{16}$ Para uma detalhada comparação entre Freyre e Tannembaum conferir RIOS, A. L. \& MATTOS, H. M. Obra citada. pp.13-34.
} 
harmonioso e no pós-emancipação isso se repetira. Já para Tannembaum, a questão central se pautava na idéia de comparar a escravidão em colônias de tradição protestante ou de tradição católica. E como lembram Hebe Mattos e Ana Lugão Rios Tannenbaum "foi pioneiro também ao enfatizar o papel do direito e da cidadania como questões centrais para a análise das relações raciais nas sociedades pós-emancipações."17

Na década de 50 vemos aparecer o maior estudioso da inserção do negro no pósabolição: Florestan Fernandes. O seu primeiro trabalho foi realizado em conjunto com Roger Bastide intitulado Brancos e Negros em São Paulo (1955). E o mais impactante no meio acadêmico teria sido A integração do Negro na sociedade de classes (1964).

Em certa medida, sua obra é uma forma de reação à idéia de democracia racial explorada por Gilberto Freyre, e, apesar de todos os problemas que hoje nos saltam aos olhos, ela deve ser considerada como de extrema valia, entre outros inúmeros motivos, por denunciar a existência do racismo. ${ }^{18}$

Todavia, não podemos nos esquecer que Fernandes vê o negro como vítima e passivo. Notemos a seguinte passagem:

(...) a formação, e a consolidação do regime de classes não seguiam um caminho que beneficiasse a reabsorção gradual do ex-agente do trabalho escravo. A ordem social competitiva emergiu e expandiu-se, compactamente como um autentico e fechado mundo dos brancos. ${ }^{19}$

Sua questão central reside em demonstrar que, devido às moléstias do sistema escravocrata, o negro sofrera um processo coercitivo que o impedia de se integrar nesta nova sociedade capitalista. Para Fernandes, o negro não estava em condições de

\footnotetext{
${ }^{17}$ RIOS, A. L. \& MATTOS, H. M. Obra citada. p.17.

18 FERNANDES, Florestan. A integração do negro na sociedade de classes. 2 vol. São Paulo, Companhia Editora Nacional, 1965.

${ }^{19}$ FERNANDES, Florestan. Obra citada. p. 457.
} 
igualdade com o imigrante europeu, já acostumado à lógica capitalista. Justamente por essa nefasta herança do período da escravidão é que o negro ficou desprovido de qualquer chance de competição. Como aponta George Reid Andrews, para Fernandes a herança da escravidão é negativa, ao passo que para Freyre esta é positiva. ${ }^{20}$

A questão passou a ser qual o papel que ex-escravos e seus descendentes tiveram no processo de abolição da escravatura? As principais contribuições historiográficas foram a utilização de novas fontes — tais como inventários post-mortem, processos crimes, etc - e, mais do que isso, a forma como tais fontes foram lidas, a utilização de uma abordagem centrada na visão dos "excluídos" da história. ${ }^{21}$ Creio que justamente por esta mudança no modo de conceber o processo escravista é que foi possível que a historiografia hodierna chegasse a novos paradigmas e pudesse utilizar novos instrumentos e métodos de análise. ${ }^{22}$

Na década de 80, uma nova geração de historiadores aprofundou esta nova tendência explicativa. A partir destes estudos os trabalhos que se eguiram, sobre as classes trabalhadoras, ganharam novos estímulos e significados. Em síntese, estabeleceu-se uma crítica à maneira como a bibliografia sobre o tema "representava" os trabalhadores e suas experiências na história, isto é, uma tendência a enxergar a história dos trabalhadores apenas nos movimentos políticos organizados.

Mas faltavam ainda estudos centrados no pós-emancipação, propriamente dito. Isso não ocorria porque, entre outros motivos, havia, na maioria dos casos, uma

\footnotetext{
${ }^{20}$ ANDREWS, G. R. Obra citada.

${ }^{21}$ Os primeiros historiadores a empregarem a noção thompsoniana aos estudos de escravidão foram Robert W. Slenes e Pedro Carvalho de Mello no artigo "Paternalism and social control in a slavery society: the cofee regions of Brazil, 1950-1888". In: IX Congresso Mundial de Sociologia. Uppsala, agosto de 1978 (mimeo). Apud LARA, S. H. "Blowin in the Wind - E.P Thompson e a experiência negra no Brasil", Projeto História. São Paulo. Revista do Programa de Estudos Pós-Graduados em História e do Departamento de História PUC-SP. n 12. p.47, outubro de 1995,

${ }^{22}$ Sobre o processo crime especificamente o primeiro trabalho a utilizá-lo como fonte de análise sistemática foi o de FRANCO, M. S. C.: Homens livres na ordem escravocrata. São Paulo, IEB, 1969.
} 
dificuldade imensa em se precisar a cor das pessoas na documentação produzida pós 1888.

Ao longo dos últimos 10 anos, a produção tem tido crescimento significativo. Estudos circunscritos a aspectos mais gerais relacionados à estruturação da economia têm cedido espaço a uma historiografia que está preocupada em discutir as estratégias que esta parcela da população adotou para conseguir a tão sonhada integração social. Trabalhos sobre São Paulo, Rio de Janeiro, assim como sobre regiões pouco exploradas ainda pela bibliografia como a Zona da Mata Mineira, Rio Grande do Sul, o Recôncavo Baiano, o alto sertão da Bahia. ${ }^{23}$ Estudos bastante variados por sinal. Pouparei o leitor de um enfadonho debate bibliográfico, mas, por afinidades na forma de concepção do processo e trato com as fontes me deterei mais um pouco em dois trabalhos cujos caminhos busquei trilhar (espero que com algum êxito) - posto que desenvolvem uma metodologia bastante atraente para os fins que estou buscando; são os de Hebe Mattos e Walter Fraga Filho. ${ }^{24}$

Hebe Mattos, por exemplo, diante da dificuldade de identificar os negros na documentação oficial pós-emancipação, inverte a ordem das cousas. Transformou falta em solução, em problema histórico. O período imediato ao fim da escravidão é momento privilegiado para se notar mudanças de referenciais culturais, que até então pautavam as relações econômicas, a convivência social e as relações de poder. Através da seleção de pequenos fragmentos de histórias de vida temos o reconhecimento desses sujeitos enquanto agentes históricos, mas sem perder, porém, a dimensão do coletivo. Por outro lado, ocupa-se do processo de formação de identidades, levando em conta o

\footnotetext{
${ }^{23}$ Vide, entre outros: MATTOS, H. M. "Laços de família e direitos no final da escravidão. Obra citada; ANDREWS, G. R. Obra citada; FRAGA FILHO, W. Obra citada; MARTINS, R. L. M. Obra citada; ALBUQUERQUE, W. R. de. Obra citada; WEIMER, R. de A. Obra citada.

${ }^{24}$ Conferir, respectivamente: MATTOS, H. M. Das cores do silêncio. Obra citada; e FRAGA FILHO, W. Encruzilhadas da liberdade. Obra citada. PIRES, F. N., Fios da Vida. Tráfico interprovincial e alforrias nos Sertoins de Sima-Bahia, 1860-1929. São Paulo, Annablume/FAPESP, 2009.
} 
declínio do sistema escravista de modo a formar um mosaico a respeito da gênese do trabalhador negro que habitava o sudeste entre a segunda metade do XIX e o começo do século $\mathrm{XX} .^{25}$

Walter Fraga Filho propõe um método que possibilita identificar as pessoas negras na documentação. Através do cruzamento de diversos tipos de fontes documentais, (inventários, processos-crime, correspondências policial e pessoal, registros de batismo, casamento e óbito, memórias escritas e orais, entre outras) entre variadas séries, seguindo as pessoas no espaço e no tempo, ele consegue traçar suas trajetórias individuais. Por meio dos nomes e sobrenomes ele reconstitui as redes sociais, abrindo caminho para perceber as mudanças ao longo dos anos (1870-1910). Os debates políticos com relação a abolição possibilitaram aos escravos negociar com os senhores, assim como aumentava paulatinamente o grau de interferência do poder público na relação senhor - escravo, outrora inviolável.

Esses novos estudos possuem um enfoque que incide sobre dois campos centrais; contar o cotidiano da marginalização, através das mais variadas políticas de dominação conscientemente projetadas (embora às vezes apareçam de forma dissimulada) e as múltiplas estratégias de sobrevivência, tanto discursivas quanto simbólicas, que as pessoas de pele escura adotavam na querela por terem suas cidadanias reconhecidas.

Afinal, finda a escravidão legal no Brasil, como esses agentes sociais passaram a serem vistos e se verem como iguais? Qual peso teve um ato jurídico de tal envergadura na vida dessas pessoas?

\footnotetext{
${ }^{25}$ MATTOS, H. Das cores do silêncio. Obra citada.
} 


\section{\begin{tabular}{l|l} 
CAPÍtULO & 1 \\
\hline
\end{tabular} \\ O PAllCO, f(S) (IDADE(S)}

Quem tiver de ir pra Campinas,

Leve contas pra rezar,

É Campinas purgatório,

Onde as almas vão penar...

Tio Chiquinho ${ }^{26}$

\section{I (DO PROBLEMA)}

Quando me pus a redigir esse texto questionei-me se mais apropriado seria começá-lo com a apresentação do espaço, onde se passa a maior parte da ação, ou dá-lo a conhecer durante a narrativa, em gotas. A última opção me pareceu, e ainda me parece, estilisticamente mais atraente; todavia a ausência de uma introdução ao assunto obrigaria o autor a longas digressões que, além de dissolver o ritmo da narrativa, preencheriam o papel inutilmente. Não há hesitação possível: a feitura de um capítulo se faz imperativa.

Como se apresentava Campinas na belle époque? Essa mesma pergunta foi feita por outros autores em outras oportunidades, contudo, antecipo que a despeito de estar com ela - a pergunta - em suspenso durante todo o capítulo, privilegiarei, continuadamente, os aspectos e os pontos de vista dos sujeitos protagonistas dessa dissertação, ou seja, as pessoas negras, fossem elas ex-escravas, ex-libertas ou geração posterior. Explorar as relações que teciam com a cidade, com os espaços - assim como com os demais grupos sociais - é o que me inspira interesse; conhecer seus anseios e intenções é a motivação, que, notadamente, dita a constituição daquela. Como essas

\footnotetext{
${ }^{26}$ Tio Chiquinho é um ex-escravo que concedeu uma entrevista para um articulista do Jornal O Getulino. Sobre o Getulino vide: AMANCIO, K.. A. de O. Obra citada; MIRANDA, Rodrigo. Obra citada.
} 
personagens locomoviam-se nesse ambiente claramente hostil? De que maneira viviam (n)essa cidade? Alcançar como se apresentava a Campinas desse período para estas pessoas, portanto, é a finalidade desse capítulo.

\section{II (DA EPÍGRAFE)}

Agora que já tornei conhecidos os motivos que viabilizaram a escrita do presente capítulo, passemos à história propriamente dita. Atentou o leitor à epígrafe? Vejo aí um bom ponto para o início. Trata-se de versos mencionados por um ex-escravo (Tio Chiquinho) na ocasião de uma entrevista concedida na década de 1920. Embora breves essas linhas encerram diversas questões relevantes. Tomemo-las por evidência e façamos o exercício de interpretação que se segue:

Se o leitor é dado ao gênio melancólico, da leitura dos ditos versos imagina que Campinas é cidade intensa e ameaçadora, escassa de gente e de sangue para o trabalho; trabalho esse que, ao que aparenta, estava longe de ser ofício leve. Como é sabido, recrutar-se-iam, destarte, centenas e mais adiante milhares de escravos oriundos de regiões outras para ocuparem os novos postos na lavoura (haja vista que a expansão do café só fazia crescer). Os versos documentam, assim sendo, uma história da opressão, carregada de emoção, sentimento e injustiça.

Suponhamos, porém, que o leitor não é dado a estes devaneios e melancolias; nesse caso imagina uma Campinas totalmente diferente da outra. Desta vez os interpretará como agência do velho escravo ou(e) da folha em questão. Sim, posto que esse jornal possuíam objetivos políticos bastante precisos - veiculavam a necessidade da integração social dos negros na sociedade pós-emancipada. O Getulino. Conhece o leitor? Seu subtítulo era "orgam para a defesa dos interesses dos homens pretos", mais 
tarde substituiu-se o "pretos" por "homens de cor" (talvez indicando ascensão social de seus articulistas ou mudança de público alvo). ${ }^{27}$ Esse é um daqueles casos em que o nome da coisa diz quase tudo que há para se falar sobre ela. Não resta dúvida que o título da folha é referência ao pseudônimo adotado por Luiz Gama em sua famosa obra: Trovas Burlescas de Getulino. ${ }^{28}$ Nada me parece mais astuto, e lógico, do que apostar numa imagem negativa para cidade; apanhar no passado as origens dos problemas que lhe turvam o presente pode ser entendido como estratégia política.

Mais esperto que os outros, acode ainda um leitor dizendo que as duas hipóteses não são excludentes mas perfeitamente plausíveis. Essa é a opinião do autor, aliás. A cantiga informa quão desnorteador devia ser o trabalho no campo, assim como o desenraizamento - em especial esse caso, quando ambos os acontecimentos foram conjugados. Essa situação devia ser duplamente desconcertante para os escravos. O trabalho no campo, via de regra, era tido por estes por mais intenso, insalubre e cerceador, o que, dentre outras coisas, lhes dificultavam as possibilidades de acumular pecúlio; ao mesmo tempo o deslocamento, quase sempre para um lugar desconhecido, lhes privaram do contato com sua rede de sociabilidade habitual, implicando diretamente, mais uma vez, em suas possibilidades de ascensão social e de autonomia; era-lhes obstado, consequentemente, o viver de si mesmo, o tornar-se senhor de suas ações, a conquista da liberdade, enfim...

\footnotetext{
${ }^{27}$ De posse dos Irmãos Andrade $O$ Getulino foi publicado semanalmente de 29 de julho de 1923 à 13 de maio de 1926. Sua tiragem foi de 1.500 exemplares, um número considerável para este tipo de imprensa, ainda mais se considerarmos que a população campineira entre os anos de 1920 e 1926 passa de 115.602 à 122.257 mil habitantes e que a quantidade de negros e mulatos varia de 20.557 à 17.898 mil pessoas. Isto significa que a quantidade de negros varia respectivamente de $7,3 \%$ à $8,3 \%$ da quantidade de negros existentes na cidade. Sobre os dados populacionais consultar MACIEL, C. da S. Discriminações Raciais - negros em Campinas 1888-1926. $2^{\mathrm{a}}$ ed. Campinas, Área de publicações/Centro de Memória da UNICAMP, 1997.

${ }^{28}$ Luiz Gama foi importante personagem na luta abolicionista. Destacou-se, fundamentalmente, por sua atuação junto a justiça, posto que era rábula e tornou-se famoso, entre outras coisas, por evocar a lei de 1831 a fim de conseguir a libertação de escravos. Sobre sua vida e obra CF. AZEVEDO, Elciene. Orfeu de Carapinha: a trajetória de Luiz Gama na imperial cidade de São Paulo. Campinas, Editora da UNICAMP, 1999.
} 
O caráter extremo dessa problemática - a perda da faculdade de se governar por si mesmo - produz certa inquietude que se revela na busca desses sujeitos por uma forma de vivência mais apropriada, menos restritiva. É a manifestação de um pensamento transgressor, que projeta em si uma obscuridade incerta. Estabelece-se aí a possibilidade de subversão política.

Emerge ainda, dos mencionados versos, que as circunstâncias, que particularizaram a cidade de Campinas durante o século XIX, incitaram nos escravos um crescente sentimento de tolhimento e impotência revelada. Afinal se era a Kalunga, para os africanos bantos escravizados no novo mundo, a travessia do mundo real para o espiritual (logo transpor, em navios negreiros, a Kalunga era signo de uma morte antecipada, nas mãos dos brancos), ${ }^{29}$ Campinas se apresenta como o entre-lugar, no qual as almas estão na condição ou processo de expurgação, que precede um lugar melhor.

Essa capacidade infringente manifestou-se através de diversos canais. Dos mais grandiloquentes, como o plano de revoltas de 1832, às fugas (tanto individuais quanto em massa) e assassinato de senhores. E não nos esqueçamos ainda de quando acionavam meios legais, a fim de alforriarem-se através das ações de liberdade. ${ }^{30}$

\footnotetext{
${ }^{29}$ SLENES, R. Malungu ngoma vem! África coberta e descoberta no Brasil. Revista da USP, São Paulo, n. 12, 1991-1992, p. 12-67.

${ }^{30}$ No ano de 1832 foi descoberto um plano de revolta escrava em Campinas envolvendo quinze fazendas. Sobre o assunto CF: PIROLA, R. F. A conspiração escrava de Campinas, 1832: Dissertação (Mestrado em História), IFCH, UNICAMP, 2005; e a respeito de escravos que matavam senhores vide; ALVES, M. C. Quando falha o controle: crimes de escravos contra senhores (1840-1870), Dissertação (Mestrado em História Social), FFLCH, USP, 2010. Com relação as ações de liberdade vide o estudo pormenorizado de XAVIER, R. C. L. A Conquista da Liberdade: Libertos em Campinas na segunda metade do século XIX. Campinas, Área de publicações/Centro de Memória UNICAMP, 1996.
} 


\section{III(DA REPRESSÃO)}

O impacto dessa situação externa sobre o "elemento negro" é surpreendente. Ele se viu tolhido dos anseios de perpetuar a parcela da herança cultural, que atravessava a escravidão ou se formava graças a ela. Contudo, ficou imobilizado dentro de um tradicionalismo tosco e inoperante. Ambas as coisas relacionam-se, estrutural e dinamicamente, com o destino encontrado pelo negro e pelo mulato naquele ambiente urbano, Até providências policiais foram tomadas para impedir a "revivescência", à noite, de "antigos usos", que perturbariam o sossego e, talvez o decoro da população branca. As perdas culturais daí resultantes não foram, porém, compensadas pela aquisição de valores culturais alternativos. $^{31}$

A passagem acima, extraída do clássico trabalho de Florestan Fernandes $-A$ integração do Negro na Sociedade de Classes - resume com precisão, ao que me parece, a postura da classe dirigente diante da população negra nos anos subseqüentes ao treze de maio. Isso fica bem demonstrado ao longo de sua obra, em diversas passagens, assim como na maioria dos trabalhos posteriores pertinentes ao tema. ${ }^{32}$ Contudo (como o leitor deve desconfiar a essa altura) sua interpretação, a herança negativa da escravidão, "as perdas culturais" não é compartilhada pelo autor.

\footnotetext{
${ }^{31}$ FERNANDES, Florestan. A integração do negro na sociedade de classes. Obra citada. vol.2, p.69. 69.

${ }^{32}$ Para citar alguns lugares bastante diferentes em que esse fenômeno foi observado CF. CHALHOUB, S. Trabalho, Lar e Botequim: o cotidiano de trabalhadores no Rio de Janeiro da Belle Époque. $2^{\mathrm{a}}$ ed. Campinas, Editora da Unicamp, 2001;BRETAS, M. L. Ordem na cidade - o exercício cotidiano da autoridade policial no Rio de Janeiro: 1907-1930. Rio de Janeiro, Rocco, 1997; TÍEDE, L. M. Sob suspeita, negros, pretos e homens de cor em São Paulo no início do século XX. Dissertação (Mestrado em História), IFCH, UNICAMP, Campinas, 2006; ROSEMBERG, A. Polícia, policiamento e o policial na província de São Paulo no final do império: a instituição, prática cotidiana e cultura. Tese (Doutorado em História Social). São Paulo, FFLCH, USP, 2008. São Paulo, FFLCH, USP, 2008. ANASSI, V. P. Vivenciando uma Cidade em Transformação: Cotidiano de classes populares no centro de Florianópolis (1900-1920). (TCC) UFSC, Florianópolis, 2009. Faço um adendo de que nem todos os trabalhos que cito acima não estão focados em discutir o pós-emancipação como meta principal, contudo todos chegam, em alguma medida, concordar parcialmente (no tocante a ação policial) com o excerto citado acima.
} 
Todas essas questões, que ventilei até aqui, remetem-nos a como seria a Campinas que habitava as mentes dos escravos, e, ao mesmo tempo, diz muito sobre o momento da entrevista, sobre seu presente. Evidência de que as coisas não iam nada bem, em Campinas e no restante do país, afinal liberdade é diferente de igualdade. ${ }^{33} \mathrm{Um}$ episódio que registra isso, com precisão, é o da lei de restrição a mendicância. Lei essa que não se dirige especificamente aos negros, mas é certo que este era o grupo alvo e mais propenso a ser afetado, por motivos que bem sabemos. Vejamos o que diz a resolução de 21 de maio de 1889:

Art.1 Fica proibida a mendicidade nesta cidade e município, salvo nas condições seguintes:

1. - Todo o individuo que ficar impossibilitado de ganhar a subsistência pelo exercício de qualquer trabalho licito, se dirigirá ao presidente da câmara municipal a quem justificará a verdade de seu estado e, por ordem deste, receberá na secretaria da Câmara uma guia para o fiscal de sua paróquia, á vista da qual o fiscal registrará em lugar bem visível na ocasião de esmolar, só nas quartasfeiras e sábados. Estas chapas são intransferíveis. O que infringir a postura, cedendo ou ocupando chapa de outrem, será punido com oito dias de prisão e o duplo na reincidência, e por qualquer outra infração dois dias de prisão. $^{34}$

Essa história que espanta pela peculiaridade indica que, além das intenções políticas da folha, Campinas não devia ser lugar em que a tolerância fosse lá muito apreciada. Esse tipo de política está ligada intrinsecamente à política de repressão a vadiagem, assunto que veremos com menos pressa no capítulo próximo.

\footnotetext{
${ }^{33}$ CUNHA, O. G. \& GOMES, F. dos S. Quase-cidadão: histórias e antropologias da pós-emancipação no Brasil. Rio de Janeiro: Editora FGV, 2007.

${ }^{34}$ TELLES, J. C da S. Repertório das Leis promulgadas pela Assemblea Legislativa da Provincia de s. Paulo desde 1835 até 1875. São Paulo, Typog. Do Correio Paulistano, 1877. Apud LAPA, J. R. do A. . A cidade: Os Cantos e os Antros. Campinas 1850-1900. São Paulo, EDUSP, 1996.
} 
A estranheza, contudo, é uma porta interessante para se tentar entender o passado. Esse tipo de situação nos faz perceber que estamos, de fato, estudando um mundo muito diferente do nosso. Mundo esse em que, veja o leitor - mendigos tinham de (ao menos era o que a resolução recomendava) em se pedindo esmolas o fazerem em locais e dias pré-determinados, bem longe dos sensíveis olhos e narizes das "famílias de bem" que se sentiam constrangidas à saída do teatro ou à missa. Além disso, ser pedinte era quase um ofício, o sujeito que quisesse seguir nesse ramo devia ir a prefeitura pedir autorização ao presidente da câmara. Em lá estando eram distribuídas, pela autoridade competente mediante exame igualmente competente, chapas contendo um número de registro aos mais aptos. Verificava-se se o candidato a pedinte era ou não merecedor da famigerada chapas ou era apenas um vadio comum. ${ }^{35}$ Na prática o que se verificou foi um profícuo comércio subversivo de aluguel de chapas. Acontecimento esse que deixava as autoridades consternadas. Esse tipo de ação fazia parte de uma política que visava construir uma cidade sem os indesejáveis: mendigos, os vadios, prostitutas e excluídos em geral... Contudo, como isso nem sempre é possível, o que notamos é a existência de duas cidades.

\section{IV (DUAS CIDADES)}

Como a maioria das cidades que passaram por processo de reestruturação semelhante, havia uma divisão muito clara, eram duas as Campinas. ${ }^{36}$ De um lado acompanhamos o nascimento de uma cidade que se pretendia racional, burguesa e pudica - quase

\footnotetext{
${ }^{35}$ MACIEL, C da S. Obra citada.

${ }^{36}$ Em alguns momentos, o leitor que teve contato com a literatura pertinente ao tema, notará que o processo descrito em muito se assemelha com cidades como São Paulo, Rio de Janeiro, Salvador e Desterro. O que difere são as soluções que seus respectivos governos encontraram para resolver semelhante incomodo. Sobre as características de Campinas vide LAPA, J. R do A. Obra citada, p.124.
} 
européia - que se definia numa linguagem arquitetônica que delega novo conceito aos espaços, postula funções e atribuições aos seus habitantes, e essa atitude impositiva precede conflito. Já a outra cidade, erguida a sombra da primeira, é clandestina, proibida e desafiadora. Escravos de ganho, lavadeiras, prostitutas, trabalhadores assalariados em geral fazem dela sua morada. Em geral se espremem em minúsculas edículas e têm sua circulação cerceada pelas autoridades competentes. Afinal a primeira cidade - a visível - onde habitava a classe dirigente, tinha ojeriza a essa outra cidade, criada a revelia. Para impedir ao máximo esse contato os órgãos oficiais de repressão, a institucionalização por excelência, optaram deliberadamente, tornar a invisibilidade cultural do segundo física. Medidas as mais diversas foram tomadas para sua efetivação. Campinas erigiu-se de acordo com uma concepção de cidade próxima a dos incipientes centros urbanos do país. Esse processo intensificou-se, tomando corpo, a partir de meados do século XIX. Na capital federal, por exemplos, tivemos a chamada “era das demolições”, capitaneadas pelo então prefeito Pereira Passos. Reforma urbana essa que acabou por destruir habitações populares (vulgos cortiços) removendo a população pobre, as ditas "classes perigosas" para bem longe do centro da cidade. ${ }^{37}$ Em São Paulo e Fortaleza chegava-se a ponto de estipular as dimensões que deveriam ter as casas operárias e cubículos; detalhamentos com relação a área mínima, pé direito mínimo, portas e janelas mínimas, porão etc. Esse tipo de construção deveria se localizar fora do perímetro comercial e somente ser edificada sob licença da Câmara. Campinas não foge a esse fenômeno. A preocupação com a salubridade das casas, quintais, ruas e esgotos também se fez presente. O código de posturas de 1873 evidencia a vontade do poder público em intervir nas áreas centrais. Contudo, não apenas esteticamente. Por trás disso há questões sanitárias, viárias, habitacionais e de classe que

${ }^{37}$ O bota abaixo culminou com a destruição do cortiço mais popular da cidade, chamado Cabeça de Porco. Há até uma charge na Revista Ilustrada que retrata isso CF. CHALHOUB, Sidney. Cidade Febril. Cortiços e epidemias na corte imperial. São Paulo: Companhia das Letras, 1996. 
informam esse tipo de ação. Observemos a seguir uma foto, datada de 1890, que retrata a região central da cidade. Ela é recorrente em livros de toda espécie que tem a cidade por tema.

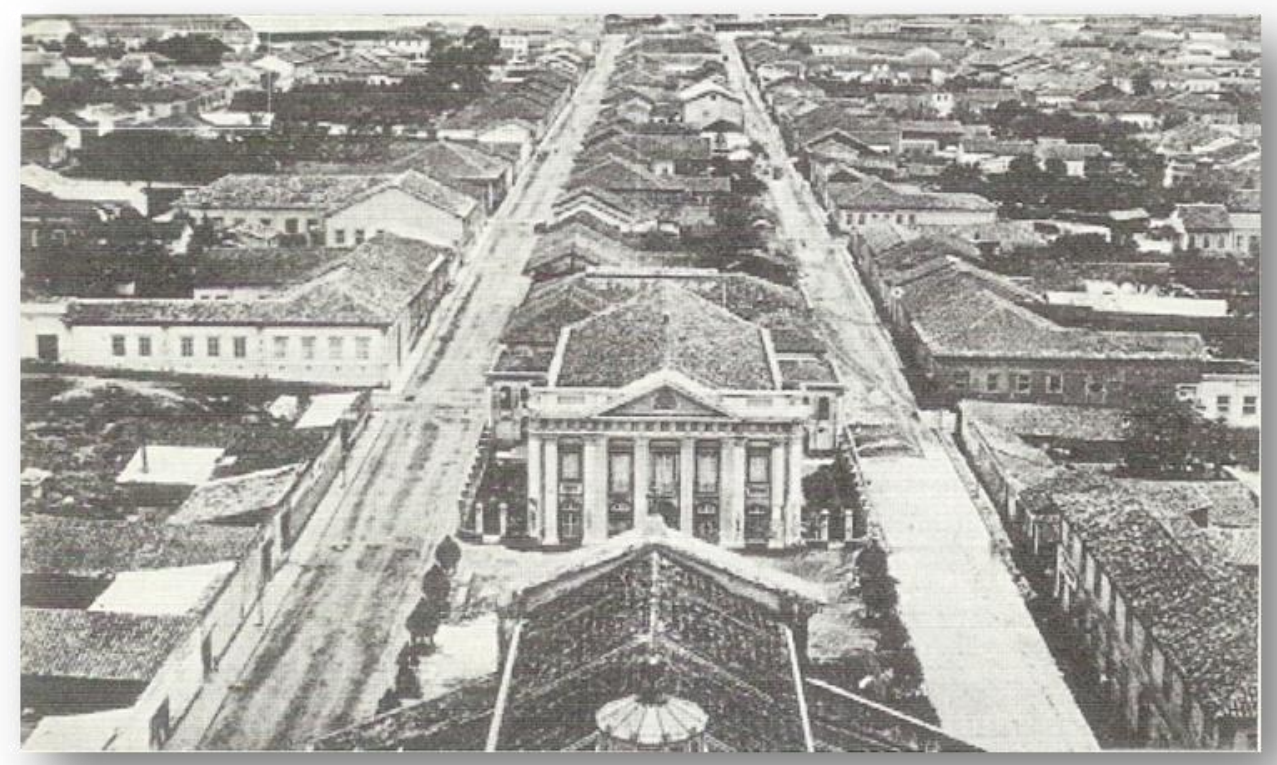

Essa foto é reveladora na medida em que esclarece o ideal de cidade que pretender-se-iam edificar. Muito provavelmente ela foi tirada do alto da matriz nova. Essa área, à essa época, era considerada nobre - haja vista o imponente Teatro São Carlos (ao centro) produzido em arquitetura Neoclássica. Acompanhado dos casarões das famílias mais abastadas. Uma dessas ruas era a São José, atual 13 de maio (vide linha verde mapa de 1900). Como podemos ver não há ainda pavimentação, mas nota-se o passeio para os transeuntes. ${ }^{38}$ A exatidão das ruas revela seu planejamento; o espaço é racionalizado, asséptico e discriminatório.

Em contra-partida, há aqueles espaços que eram tidos por indesejados. Um bom exemplo disso eram os chafarizes, um em especifico ficou bastante conhecido na cidade. Sua citação na documentação da segunda metade do século XIX é constante. Refiro-me ao chafariz do Largo da Jurumbeval. Este localizava-se à rua caracol (atual

\footnotetext{
${ }^{38}$ LAPA, J. R. do A. Obra citada. p. 25
} 
Benjamin Constant) em frente ao mercado municipal. Vejamos uma notícia de jornal que da conta de como pensavam o local:

[21/10/1885] O Sr. sub-delegado da Freguesia de Santa Cruz, fazendo-se acompanhar de praças, revistou todos os quartos e biombos existentes no Largo do Jurumbeval e rua do Caracol adjacente, encontrando diversas raparigas alforriadas que não se ocupavam em cousa alguma, uma delas até achava-se de cama e, entre as outras, fora encontrada uma escrava do Sr. Antonio José Machado, que em vez de cuidar do seu serviço de lavadeira, ali vadiava. Esta foi mandada a apresentar-se ao seu senhor e as outras intimadas para ocuparem-se em serviço honesto, sob pena de assinarem termo de bem viver. (Gazeta de Campinas,22/10/1885, p. 2$)^{39}$

Apesar de que a maior parte dos escravos eram destinados ao trabalho nas lavouras, é certo que muitos deles circulavam nos centros urbanos. Tanto isso é correto que o seu transito passou a ser controlado, seja pelas posturas municipais, como pela ação da policia. Essa notícia documenta isso. Notemos que o conteúdo da notícia da conta do sentido de condenar a atitude de "vadiar" dessas pessoas apoiando a ação policial a fim de que se trabalhem. Mesmo quando se trata de uma pessoa alforriada, a qual em tese é senhora de si (excetuando alguns casos de alforria condicional).

\footnotetext{
39 Apud MARTINS, Valter. Policiais e populares: educadores, educandos e a higiene social. Campinas, Cad. CEDES, vol.23, nº.59, abr. 2003. O largo da Jurumbeval é tema do referido artigo de Valter Martins. Ele argumenta que esse espaço constituiu durante a segunda metade do século XIX especial espaço em que a classe trabalhadora divertia-se, trabalhava e morava. A aglomeração de pessoas, sejam essas escravos, libertos, imigrantes e nacionais pobres, perturbava as autoridades que, por meio da ação da polícia cerceavam e ordenavam "os movimentos de pessoas vistas como perigosas à sociedade, por seu comportamento considerado imoral e escandaloso".
} 


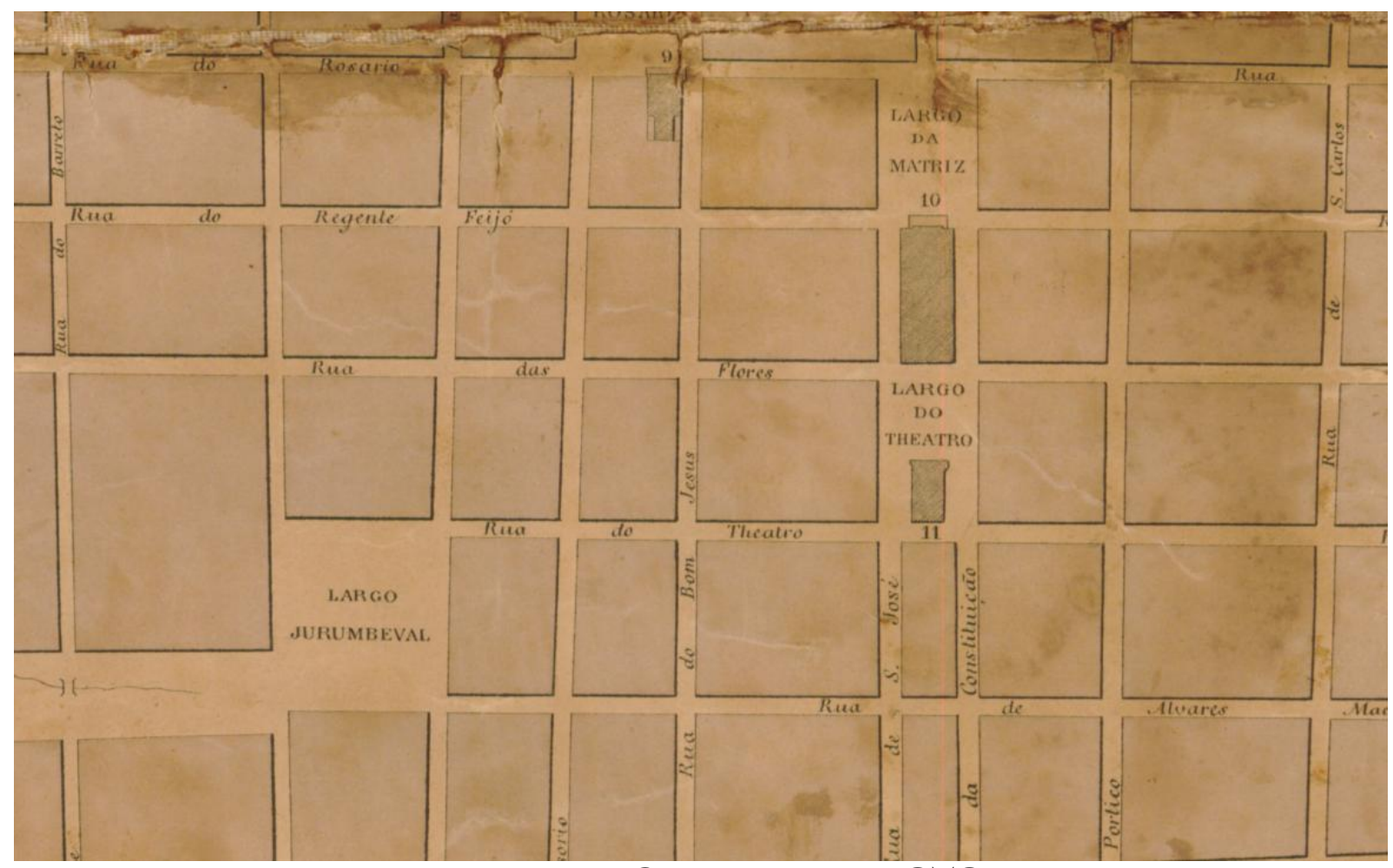

Planta DA CIDADE DE CAMPINAS EM 1878, DETALHE.

\section{V (O PALCO)}

Antes de avançar na narrativa entendo que é importante oferecer ao leitor alguns dados estatísticos para que visualize melhor o microcosmo estudado.

Campinas é cidade com vocação para a imigração. Engana-se, porém, o leitor que infere que me refiro à imigração européia. ${ }^{40}$ Essa, bem mais explorada pela historiografia, também foi intensa e maciça, mas antes disso, no século XIX ainda, um grande número de escravos chegaram a cidade. A partir de 1790, sobretudo. Para termos uma idéia mais concreta, entre 1779 e 1829, Campinas teve sua população escrava aumentada de inexpressivos 150 cativos para impressionantes 4800 . Um considerável

\footnotetext{
${ }^{40}$ No princípio do século XIX já se escutavam rumores a respeito da venturosa falta de braços escravos. Isso impulsionou um sem número de discussões a respeito das potencialidades da implementação do trabalho livre no país. Extenso debate se estabeleceu, após 1850, com a finalidade de aumentar o numero de trabalhadores livres. Deviam enfrentar o problema enquanto ainda possuíam essa faculdade, pois toda a idéia era que mais dia menos dia haveria de substituí-lo, o sistema escravocrata, pelo trabalho livre. A respeito da imigração em Campinas no século XIX conferir SOUZA, C. de L. As primeiras experiências do trabalho livre em Campinas no século XIX, dissertação de mestrado, IFCH, UNICAMP, 2008.
} 
aumento, a população escrava cresceu 32 vezes! Nessa ocasião o avanço do açúcar era o vetor principal de tal fenômeno. Essa população, assim como a da maioria das escravarias no restante do país, era composta substancialmente por africanos, mais especificamente, no caso paulista, os de origem banta. ${ }^{41}$ As taxas de fecundidade entre os escravos eram relativamente baixas a essa época e o tráfico era nesse período, um grande negócio.

Na segunda metade do século XIX o cultivo de café fez Campinas centro da economia do Oeste Paulista. Expandiu, reestruturou, consolidou e tornou-se uma das mais importantes da província. A evidente capacidade agro-exportadora propiciou a atmosfera necessária ao aumento da população cativa, como conseguinte teve seu perfil populacional modificado.

A segunda proibição do tráfico atlântico em 1850 (dessa vez não mais para inglês ver) aqueceu o tráfico interprovincial de cativos. A zona da Mata Mineira, o Vale do Paraíba e o Oeste Paulista foram as regiões receptoras dessa mão-de-obra. ${ }^{42}$ Tais circunstâncias e a malha ferroviária, que talhava a cidade, proveram o desenvolvimento urbanístico de Campinas e a formação das primeiras vilas, com igreja, praças, casas e ruas. $^{43}$

Em 1872 esse número chegava à casa dos 14 mil escravos. O comércio desse gênero mostrou maior robustez entre as décadas de 1850 e 1860, no entanto o tráfico interno recrudesceu em 1870. Em 1881 o governo passou a tributar a importação dos escravos o que fez com que esse fluxo se interrompesse. Mudança de atitude que

\footnotetext{
${ }^{41}$ SLENES, R. W. A. "Malumgu..." Obra citada.

${ }^{42}$ MIRANDA, Cristiany. Gerações da Senzala: famílias e estratégias escravas no contexto dos tráficos africano e interno. Campinas, século XIX. Tese (Doutorado em História), IFCH, UNICAMP, Campinas, 2004.

${ }^{43}$ Processo esse que Lapa denominou de "modernização tardia" LAPA, J. R. do A. A cidade os cantos e os antros.
} 
coincide com a queda de produtos agrícolas na Itália, que expele o trabalhador do campo para as terras paulistas. ${ }^{44}$

Em sua maioria, a população migrante adentrava no país com intenção de trabalhar no campo, era essa a regra, posto que São Paulo fosse ainda uma província eminentemente agrícola.

${ }^{44}$ SLENES, R. W. A. Senhores e Subalternos no Oeste Paulista. In História da vida privada no Brasil. Vol.2, pp. 233.290. 
1

\section{PLANTA DA CIDADE DE CAMPINAS}

\section{E SEUS EDIFICIOS PRINCIPAES}

LEVANTADA EM 1878

$=1$

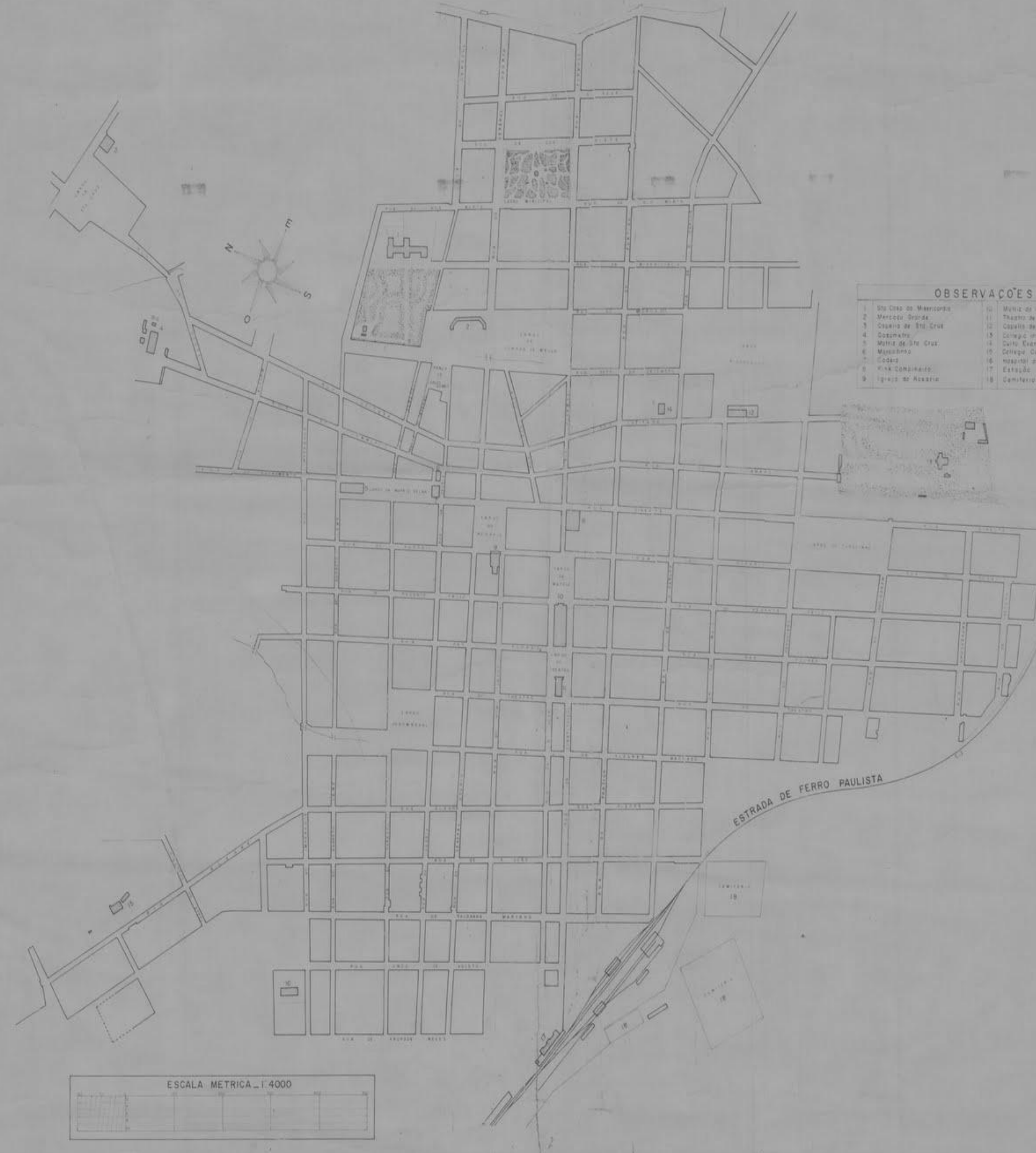




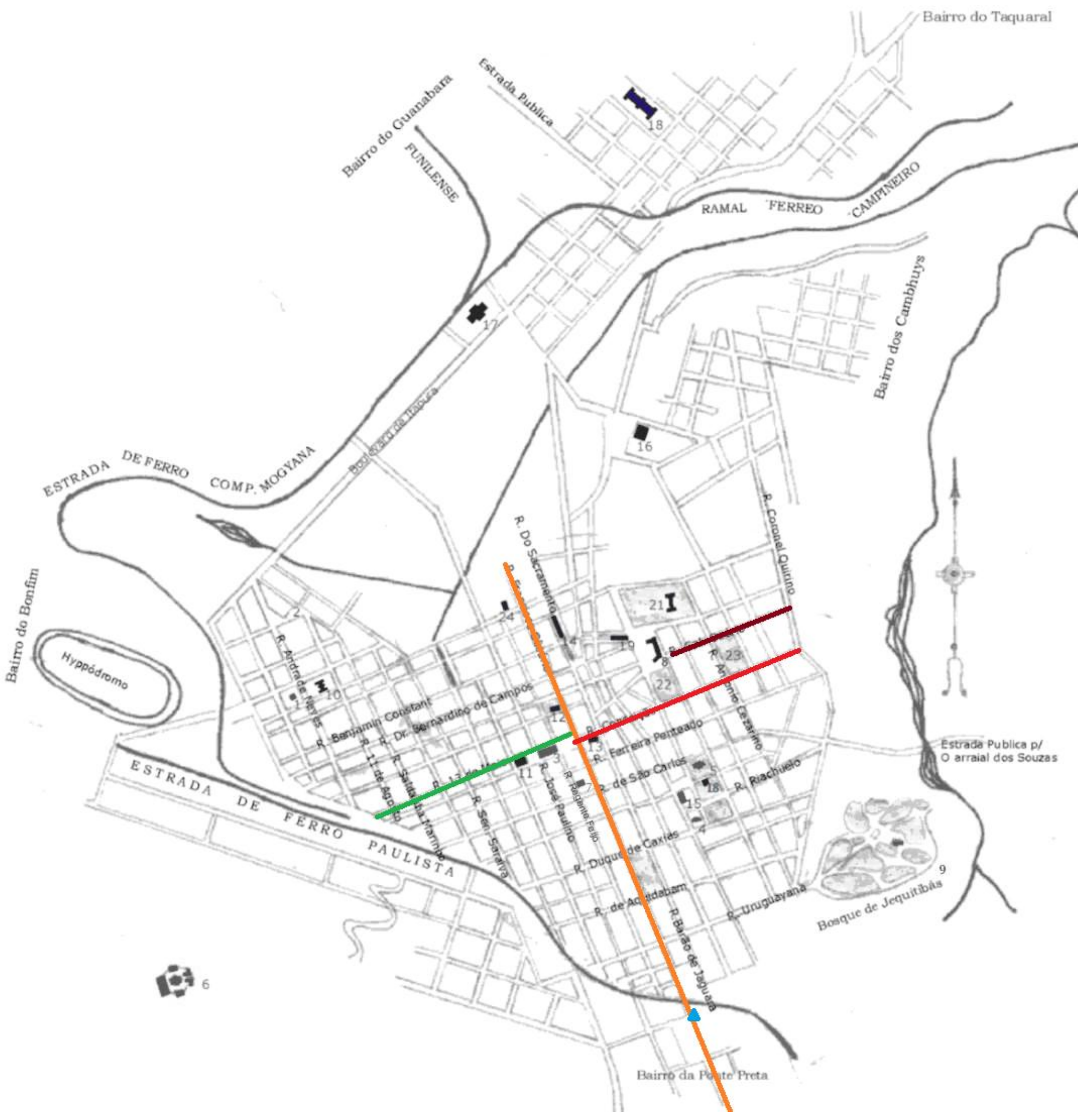

Desenho produzido a partir do Mapa Campinas em 1900, CMU, UNICAMP. 


\section{VI (DA HABITAÇÃO E DO CRESCIMENTO URBANO)}

A dinâmica da reprodução da economia cafeeira exigiu um segmento urbano complementar para suportar as atividades industriais. Uma reestruturação econômica, capaz de assegurar sua inserção num mundo em transformação, era a vontade da classe dominante.

A prosperidade econômica do final do século implicou num número grande de empresas a instalarem-se na cidade. ${ }^{45}$ Contudo, os surtos de febre amarela que assolaram a região modificaram o quadro. ${ }^{46}$ Com as epidemias do final do século (1889 e 1897) o contingente populacional da cidade diminui rigorosamente e muitas empresas rumaram, conjuntamente, para São Paulo. ${ }^{47} \mathrm{O}$ poder público, por sua vez, tomou certas medidas, assinalando drásticas mudanças no tocante à disposição dos diversos sujeitos no espaço urbano.

A iniciativa privada também buscava soluções, dentre elas destaque para a grande quantidade de instituições que foram criadas a fim de abrigar um contingente populacional que se via a vagar pelas ruas. ${ }^{48}$ Haja vista que o número de órfão e mendigos cresceu consideravelmente. Instituições como o asilo dos Mendigos/ Inválidos e a Sociedade Protetora dos Pobres. ${ }^{49}$

\footnotetext{
${ }^{45}$ NOMELINI, P. C. B. Associações operárias mutualistas e recreativas em Campinas (1906-1930). Dissertação (Mestrado em História), Campinas, IFCH, UNICAMP, 2007.

${ }^{46}$ Sobre febre amarela em Campinas conferir: SANTOS FILHO, L. de C. A febre amarela em Campinas: 1889 -1900. Campinas, Área de Publicações/ Centro de Memória Unicamp, 1996; XAVIER, Regina Célia Lima. "Dos males e suas curas". In: CHALHOUB, Sidney; MARQUES, Regina Beltrão; SAMPAIO, Gabriela dos Reis; SOBRINHO, Carlos Roberto Galvão. (Org.). As artes e ofícios de curar no Brasil: capítulos de história social. Campinas, Editora da Unicamp, 2003.

${ }^{47}$ Durante a epidemia de febre amarela havia 30 óbitos por dia, totalizando 2.000 mortes durante todo o surto. CF: BAENINGER, Rosana. Espaço e tempo em Campinas Migrantes e a expansão do pólo industrial paulista. Campinas, Area de publicações Centro de Memória UNICAMP, Campinas, 1996. Vide

${ }^{48}$ A partir da iniciativa privada, foram criadas diversas instituições, tais como o Liceu de Artes e Ofícios (1897 - orfanato que ensinava as funções de tipografia, encadernação, alfaiataria, carpintaria e sapataria); o Asilo dos Mendigos / Inválidos (1904); Sociedade Protetora dos Pobres (1889 que promoveu campanhas para assistir as pessoas carentes); Sociedade Cruz Verde (1889 associação de brasileiros e italianos para prestar socorros aos doentes da epidemia). CF: NOMELINI, P. C. B. Obra citada. p.36

${ }^{49}$ NOMELINI, Paula Christina Bin. Obra citada.
} 
Afora isso as transformações urbanas foram muitas. Há vários indícios disso. Da documentação produzida pelo município, em especial os códigos de postura que regulavam os espaços, almanaques, noticias de jornais aos processos judiciais, essas fontes nos levam a essa conclusão. E assim sendo onde habitavam os negros? Posto que várias indícios nas fontes apontam sua presença na vida citadina. Certo é que circulavam por toda cidade, embora habitassem regiões muito específicas da cidade. Através dos processos pude identificar que a maioria dos endereços dessas pessoas remetia às ruas Barão de Jaguará, Francisco Glicério e afins. Ao que tudo indica a partir daí é que começava essa Campinas clandestina e preterida pelas autoridades. Essa região era das mais visadas pela polícia, tendo em conta a presença de botequins (espaços de sociabilidade e lazer onde, supostamente, negros e mulatos passavam o dia a vadiar).

Próximo a esses espaços de sociabilidade havia também habitações coletivos, edículas, os chamados cortiços. Para ilustrar aqui escolhi dois casos, entre vários possíveis, em que pudesse discutir alguns temas que me parecem pertinentes de esse explorar. Acompanhemos, a partir daqui, dois casos, duas histórias; uma de 1890 e outra de 1914, a primeira uma denúncia de furto a outra um caso de defloramento, cada qual oferece a possibilidade de descobrir, para além das representações jurídicas, as questões políticas que estavam em pauta. Veja o leitor, por exemplo, como o delegado Bandeira de Mello enuncia o caso de 1914: "Num tendeiro existente no quintal do prédio n' 68b da rua Alvares Machado, habita miseravelmente com sua família, um pobre homem, inutilizado pelo álcool e moléstia, de nome João Bento Telles Cavalheiro". ${ }^{50}$ Visivelmente essa família vivia sob algum tipo de habitação coletiva. Mas antes de prosseguir na narrativa vou explicar o caso ao leitor, para que não se perca

\footnotetext{
${ }^{50}$ Processso n ${ }^{\circ} \mathbf{0 6 6 0}$.
} 
nos pormenores desta história. Parece-me que o melhor modo de apresentar essa história seja pela fala da reclamante:

Consta na ocasião do interrogatório dessa que se chamava Maria das Dores Cavalheiro, parda, com dezoito anos de idade, solteira, brasileira, natural desta cidade, filha de João Bento Telles Cavalheiro, serviços domésticos, moradora á rua e numero acima referido, sabendo ler e escrever. ${ }^{51}$ Examinemos seu depoimento:

que em dias do mês de Maio do corrente ano, passando pela rua Doutor Quirino, ao meio dia com destino á Santa casa, onde ia visitar seu pai ali doente, ao chegar a agencia do leiloeiro João Murbach, este, para seu patrão desocupar [sic], convidou-a a entrar, pois desejava entregar-lhe umas camisas e meias para que levasse a seu pai; que a declarante ali entrando o mesmo, fechando as portas e fazendo-lhe promessas em dinheiro, convidou-a a sentarse em seu colo num sofá ali existente, deitando-a no mesmo sofá, a desonrou; que ele pediu a declarante que nada contasse a sua mãe e a amasia dele, que é afilhada de sua mãe; que em seguida o seu ofensor deu-lhe cinco mil réis e entregando-lhe um [ilegivel] de liga para que levasse a seu pai, aconselhou a declarante a que procurasse outros homens; que nessa ocasião havia empregado algum na casa de João Murbach e depois disto não teve mais relações sexuais com o referido seu ofensor; que na ocasião em que foi desonrada estava no começo de seu incômodo e que no mês seguinte deixou de ser menstruada, porém não julgou que estivesse grávida; que ocultou sempre sua desonra a sua mãe; que tendo ontem um aborto, foi sua desonra descoberta tendo a declarante confessado a sua mãe, indicando João Murbach como criminoso; que, finalmente, não tomou remédio algum para abortar, pois ignorava que estivesse grávida.

Se o leitor já fez a essa altura o exercício de verificar o mapa de 1900, notou que esse endereço fica muito próximo largo da Jurumbeval (indicação em azul), lugar que, tradicionalmente, é ponto de encontro, integração e convívio social de pessoas negras.

\footnotetext{
${ }^{51}$ A sessão foi em sua casa. Mesmo endereço que o que fora indicado por sua mãe.
} 
As testemunhas informam-nos como se apresentava o lugar - Guilhermina Olympia Ferreira, preta, com quarenta e cinco anos de idade disse na ocasião em que foi interrogada que a ofendida "Reside aos fundos do quintal da rua do mesmo já referido acima" (por acima entenda-se o endereço da depoente); Caruso Raphael de trinta e dois anos de idade, casado, funileiro, italiano informa que a família residia a um quintal na Rua Álvares Machado sessenta e oito B (quarto esse que ele e seu cunhando Miccelli sublocavam); Rosado Guisoffie, com quarenta e sete anos de idade, casado, folheiro, italiano, afirma que conhece apenas de vista a ofendida e mora também no quintal que da de frente a casa da família da vítima. Esta, juntamente com sua família, residia num pequeno quarto no quintal, não sabendo ele, entretanto, de que meios dispunham para se sustentar. E por fim Gernhura Olympio Ferreira, de quarenta anos de idade mais ou menos, viúva, também diz residir no mesmo quintal. Testemunhos que atestam ser o local deveras muito pequeno. Na ocasião em que esteve no Júri, em outro momento deste processo que o das testemunhas acima descritas, há ainda o testemunho de Washington Ataliba Nogueira, brasileiro, solteiro, com quarenta e cinco anos, intermediador de negócios que afirma que sabe que a família da ofendida reside há muito num sobrado de propriedade de seu pai.

Bom, mas como o leitor deve ter notado a essa altura a ofendia é descrita por parda. Mas o que significa isso exatamente? Por este mesmo processo podemos concluir que pardo é entre-lugar. A cor da reclamante é descrita em duas passagens. Nessa que citei acima, da ocasião em que se deu a declaração da ofendida e também de quando da realização do exame de corpo de delito. Dessa vez ela é referida por branca. Isso indica duas ou três coisas, certamente até mais. Saber a cor da reclamante nesse processo é algo que nos escapa. Dessa vez não por negligência, mas por excesso. De pronto temos que o termo "pardo" não é usado à toa. É entre lugar. Se por um lado aparece como 
sinônimo de branco para Maria das Dores, sua mãe, Eva Queiróz, também é descrita por parda durante sua declaração na ocasião da denúncia, ao passo que na voz de João Murbach aparece como "preta".

Notemos ainda que tanto Maria das Dores quanto sua mãe são definidas por "parda" no mesmo momento do processo. Da ocasião que se lhes eram, respectivamente interrogadas. Nesse momento quem define a cor da personagens só pode ser ou o escrivão ou o delegado. Sendo bastante provável que seja o primeiro. Imaginemos a situação. Chegam a delegacia a suposta ofendida e sua mãe. Dado as circunstâncias do caso provavelmente chegaram vestidas como de costume. Em seguida informam sobre aspectos de suas vidas que os faz inferir que se tratam de pessoas pobres senão miseráveis. Essas condições qualquer pessoa com o mínimo de ascendência africana passa a parda. Se estivéssemos nos EUA ela seria negra, contudo como no Brasil existem essas gradações - pardo, mulato e afins são assim definidas.

Em contrapartida não estou certo que o médico que efetua o exame de corpo de delito tenha acesso a essas informações. É provável que a única informação que tenha a respeito da vitima seja seu corpo e sequer tenha visto a mãe desta. Sua intenção é ser objetivo. E pelo exame exclusivo do corpo ao que lhe aparentou ela seria branca. Informação esta que contrasta com o depoimento do réu. Para este Eva de Queiróz, mãe da ofendida, é "preta que vive na ociosidade". Como pode num contexto e noutro parda significar o mesmo para uma pessoa quase branca ou quase negra? Essa frase aparece justamente num contexto em que o réu esta a se defender das acusação de ter deflorado a jovem em questão. Preto é uma palavra pejorativa, ao menos no contexto dessa região. $\mathrm{Na}$ boca de terceiros sempre aparece de forma pejorativa. Excetuando-se quando aparece no diminutivo, mas daí entra a questão da infantilização. 
Porque essa diferença? Como pode uma pessoa mudar de cor em poucas páginas? Diferentemente de contextos como, por exemplo, o sul-africano, em que se definia a cor das pessoas por negação (White/Not White/Coloured) ou ainda nos Estados Unidos onde se definia quem era negro ou branco, grosso modo, de maneira bipolar. No Brasil pós-emancipação ela é definida a partir da reunião de alguns fatores. Minha hipótese é de que cor nessa sociedade tem a ver não apenas com os traços fenotípicos (para utilizar uma nomenclatura biologizante) mas com o status social e a situação financeira da pessoa em questão. Aliás, essa prática era comum no século XIX ao ponto de chocar viajantes que passavam por terras brasileiras. Além do que isso explica como a memória coletiva hodierna não se dá conta de que personagens como Carlos Gomes e Machado de Assis eram negras.

Esse caso ilustra, portanto, como cor/lugar social e situação financeira são fatores que podem torna o sujeito mais ou menos negro e informar as gradações.

\section{VII (SOBRE A COR)}

Em pesquisa já clássica sobre o Rio de Janeiro, Hebe Mattos aponta que na região estudada por ela, assim como em outras partes da Afro-América, a indicação de "cor" desaparece dos registros históricos no pós-emancipação. No caso carioca ainda no XIX, jaz um silêncio. A ausência da "cor" é acentuada tendo em vista que ao longo do XIX, ao menos para o caso carioca, esta vai se esvaindo dos registros oficiais, o que não constitui um problema para o historiador tendo em vista que seu status jurídico era indicado. O período subseqüente ao fim da escravidão é visto como um momento privilegiado para se perceber mudanças de referenciais culturais, que até então norteavam relações econômicas, convivência social e de poder. A abordagem agrega ao mesmo tempo o reconhecimento de agentes históricos e os fenômenos coletivos. Elege 
como forma de análise a seleção de pequenos fragmentos de histórias de vida para esses diversos grupos sociais e também se ocupa em analisar o processo de formação de identidades, levando em conta o declínio do sistema escravista. O último terço do livro é dedicado ao pós-emancipação. Propõe-se a pensá-lo de forma cultural, como sugere Rebeca Scott. ${ }^{52}$

Com isso em mente é que me debrucei sobre as fontes. Qual não foi minha surpresa quando pude verificar que, em Campinas, as coisas não procediam da mesma maneira. Retornemos ao caso de Benedicta: "Benedicta da Silva, preta, de dezenove anos de idade, conforme sua declaração, brasileira, mulher bem constituída" [Grifo meu]. Essas informações estão disponíveis no auto de qualificação da ofendida. Como podemos notar aparece a "cor" dela. É tida por "preta".

É difícil, em processos de Campinas, encontrar um em que não há indicação da cor dos envolvidos. A partir do final da década de 1890 sobretudo. ${ }^{53}$ É bem verdade que a "cor" aparece, especialmente, quando o processo é ainda inquérito. Quando chega às mãos do juiz e transforma-se de fato em processo só se pode precisá-la pela fala das testemunhas. Válido ressaltar que, mesmo assim, curiosamente, em escala bem reduzida são as falas em que a "cor" do sujeito em questão é mencionada. Isso provavelmente tem a ver com a padronização das falas por parte do escrivão, porém é uma questão que demandaria mais vagar do que as pretensões desse artigo.

Ainda sobre o caso de Benedicta da Silva, não só o réu e a ofendida têm suas cores citadas, mas também as testemunhas. Creio que a melhor forma para esboçar uma resposta, para entender o sentido social de cor nesse contexto, é notar como ela, a cor, aparece.

\footnotetext{
${ }^{52}$ Vide SCOTT, Rebeca. Emancipação Escrava em Cuba: a transição para o trabalho livre (1860-1899). Rio de Janeiro, Paz e Terra, Editora da Unicamp, Campinas, 1991.

${ }^{53}$ Ainda não tenho os dados quantificados, mas é certo que, a partir dessa data, encontrei um número bem maior de processos que contivessem a informação da cor da pessoa.
} 
Quando a descrição da "cor", aparece, o primeiro lugar do processo em que podemos vê-la, a descrição da "cor" é na identificação daquele que vai depor: "Lino Primo, branco, com vinte anos de idade, solteiro, brasileiro, filho de Justino de Pala Primo, já falecido, empregado, morador em São Paulo, á rua Vinte e um de Abril número noventa e seis, sabendo ler e escrever". ${ }^{4}$ São informações que permitem ao leitor do processo localizar socialmente a pessoa em questão. Oferecem elementos para que possa conferir maior ou menor peso ao depoimento. E sendo a "cor" a segunda informação a aparecer, suponho que seja elemento deveras importante. Aparece antes mesmo da idade da pessoa, ou do nome de seus pais. Não se trata de afirmar que "cor" é o único elemento que deve pesar na decisão do juiz. Entendo o direito como um campo que agrega tensões diversas. Indivíduos políticos diferentes articulam-no da maneira que mais lhes convém. Ou seja, a "cor" era elemento importante mas não determinante.

"Cor" deve ser pensada sempre como algo suscetível a mudanças no tempo e no espaço, social e culturalmente. Contextos outros, como o norte-americano, nos permite visualizar esse fênomeno com mais clareza. Um bom exemplo é o texto de Martha Hodes: The Mercurial Nature and Abiding power of Race: a transnacional family history. Trata-se de um texto fantástico. Nele a autora conta a história de Eunice Connolly e sua família. Mostra como suas escolhas de vida foram determinantes para que mudasse de país algumas vezes. Conforme mudavam de região, suas cores eram redefinidas socialmente. Em suas palavras "We tend to think of the fluid and the mutable as less powerful than the rigid and the immutable". Disso podemos extrair uma lição. Mais do que fenótipo, “cor” carrega em si valores como posição social, costumes, cultura etc.

\footnotetext{
${ }^{54}$ CMU, TJC, Estupro, 1913. Victório Gianizelli, doc. 623, of.99.
} 
Nos casos que pude examinar, quando aparece na fala das pessoas a "cor" em geral tem a função de adjetivar o indivíduo a quem se está referenciando. E tudo me leva a crer que seja de forma negativa. Vejamos um exemplo:

\section{Suicídio}

Sábado último, às 4 horas da tarde, a preta Cidenia, querendo por termo a sua existência, embebeu as vestes em querosene, atacando-lhes fogo depois. Ficou horrivelmente queimada, vindo a falecer por volta das $10 \mathrm{~h}$ da manhã.

O fato se deu na José Paulino, onde morava Cidenia. ${ }^{55}$

Em pesquisa sobre Rio Claro, Warren Dean verifica que, naquela cidade, o negro, em alguns casos, continuou trabalhando na fazenda com salário mais baixo que o de um branco. Quando não o fez, na maioria das vezes, foi porque se dava preferência ao europeu para se tornar "colono". Os que não trabalhavam nas fazendas foram morar em periferias. Apareciam freqüentemente nas páginas policiais, geralmente com o adjetivo "preto". 56

Vejamos, pois, um exemplo de como costumam aparecer nos processos criminais:

(...) hoje, entre dez e onze horas da manhã, quando prepara o almoço, para seu marido, o qual [por] volta das oito e meia saíra com o camarada Manoel Pedral a tirar capim a distância de um quilômetro, entrou-lhe em sua casa um preto até então desconhecido dela declarante; que [o] dito preto é de estatura regular antes magro que gordo, tem olhos meio vesgos e mira com as pálpebras semi-cerradas, e apresenta alguns fios apenas de cabelo na barba; que o mesmo individuo vestia calça de sarja azul [ilegível], colete de igual fazenda, dois paletós, sendo o debaixo de brisa branco, de algodão com riscas pretas (...) [Grifo meu]. ${ }^{57}$

\footnotetext{
${ }^{55}$ Correio de Campinas, 12 de Janeiro de 1908.

${ }^{56}$ DEAN, Warren. Rio Claro, um Sistema Brasileiro de Grande Lavoura 1820-1920. Rio de Janeiro, Paz e Terra, 1977.

${ }^{57}$ Estupro, 1904, Elias João Silva, doc: 0178.
} 
No exemplo acima temos que o termo "preto" define o indivíduo como se fosse um tipo, à la Crhistiano Junior. ${ }^{58}$ Interessante notar que a essa altura do processo já se tinha informações de quem era o referido, porém optou-se por colocar apenas esse adjetivo, "preto". Opção essa, a meu ver, altamente desqualificativa. É comum também que esses adjetivos apareçam também no diminutivo. O “mulatinho", a "pretinha"... Entendo o uso da cor em substituição ao nome como uma forma de reafirmar o lugar de inferioridade dos negros. O diminutivo, ao menos nesses casos, infantiliza. ${ }^{59}$

Em hipótese alguma vi, uma vez sequer, algum depoimento em que alguém fosse identificado como branco na fala de um depoente, tampouco encontrei processo em que se referissem a alguém como "branquinho" ou algo similar. Penso que a "cor" aparece nesses processos carregada de sentidos negativos que atrela, em última instância é uma tentativa de aproximá-los do cativeiro. É similar ao uso do termo "treze de maio", referindo-se aos que foram libertados com a lei áurea, comum no Rio de Janeiro e na Bahia $^{60}$. Outro aspecto que me chamou atenção tem mais a ver com a astúcia das ofendidas negras. Se chamá-las de "preta" aproximava-as do cativeiro, estas tentavam negociar de outra forma.

\footnotetext{
${ }^{58}$ Refiro-me às coleções de Christiano Junior, cujo trabalho compõe a maior coleção de foto de escravos do XIX no Brasil. Vide AZEVEDO, Paulo César de, e LISSOVSKY, Maurício. Escravos brasileiros do século XIX na fotografia de Christiano Jr. (1864-1866) [et ali.]. São Paulo, Ex. Libris, 1988.

${ }^{59}$ A respeito do uso do diminutivo, vide CARVALHO, Marcus. De portas a dentro e de portas afora: trabalho doméstico e escravidão no recife, 1822-1850. Salvador-BA, Afro-ásia, v. 1, n. 30, p. 41-78, 2003.

${ }^{60}$ Vide MATTOS, H. Das cores. Obra citada. e FRAGA FILHO, Walter. Obra citada.
} 


\section{VIII (UM CASO...)}

Passemos agora a analisar outro caso. Mais uma vez temos que o entorno da história nos informa sobre um pouco do que teria sido para essas pessoas a experiência da urbanização.

Há certas ocasiões, oportunas e fugazes, em que o acaso nos infligi certa postura; outras vezes, ao contrário, tais medidas são antes um benefício do que um infortúnio. Esse é o caso de Benedicto Manuel.

Minha dúvida é que não sei se lhes fale puramente que era de noite, ou se ponhase num tom mais aprazível: caía a noite na fazenda Matto Dentro.... O modo mais simples é o que melhor me acordaria a mim e ao leitor, assim como imagino ao “objetivo" promotor Antão de Moraes.

Aquela época corria o ano de 1896, portanto, já contava oito anos quando o fim da escravidão. Imagine o leitore que por volta das $8 \mathrm{~h}$ da noite faziam a ronda na fazenda, perto dos cafezais, três empregados - Amancio Rufino da Conceição, Paschoal Grecco e Franscico Cerratori. Ali estavam porque haviam sido encarregados de descobrirem o(s) autor(es) de diversos furtos recentes de café.

Acontece que a certa altura estavam os três junto a porteira que divide o pasto da fazenda do respectivo cafezal, inertes, quando avistaram surgir, ao lado deste, o "preto" Benedicto Manoel. Ás costas carregava uma saca de café. Continha, ao que se calculou posteriormente, mais ou menos uma arroba do dito gênero. Quando indagado da procedência daquele café, declarou o denunciado que o apanhara de um monte, situado à margem do caminho. Pelo que foi preso e entregue ao administrador da fazenda. Sendo conduzido, mais tarde, à cidade. Em certo momento procurou ainda o denunciado evadir-se, não logrando, porém, seu intento, pois foi imediata e novamente preso. 
As linhas acima condensadas foram produzidas a partir da sinopse, que aparece logo no início do processo, oferecida pelo citado promotor. O caso é relativo ao processo que Dona Anna Joaquina do Prado Aranha moveu contra o réu Bendicto Manuel.

Acompanhemos cronologicamente o processo. As falas das testemunhas, ainda na delegacia, aparecem logo em seguida. Seguem ipsis litteris:

\section{Testemunhas}

1 ${ }^{a}$ Ananias Porfírio da Conceição, com trinta e oito anos de idade, solteiro, brasileiro, ser camarada da fazenda Matto Dentro há muito tempo, não sabe ler nem escrever.

Respondeu que como de costume e a mando do seu patrão, sempre tem feito a noite rodna nos cafezais* da fazenda, onde tem havido pequenos furtos de café, e ontem pelas oito ou nove horas da noite achava-se ele depoente em companhia de Paschoal e Francisco, camaradas da mesma fazenda, parados junto da fronteira que divide o pasto da fazenda com cafezal, e ali apareceu, vindo do lado do cafezal um vulto, como eles estavam ali de vigia, cercaram-no, e verificaram que era Benedicto Manoel que conduzia um saco de café, contendo mais ou menos uma arroba; que interrogado, por ele depoente qual a procedência daquele café, respondeu Benedicto que havia tirado de um monte de café que havia no caminho; então ele depoente e seus companheiros conduziram-o a fazenda e entregaram ao administrador, voltando novamente para o seu serviço. (...)

$2^{\mathbf{a}}$ ) Paschoal Grecco, com vinte e oito anos de idade, solteiro, camarada na fazenda Matto Dentro, brasileiro, digo italiano, sabe ler digo não sabe ler nem escrever.

Disse que ontem a noite, isto pelas oito horas mais ou menos, achava-se ele depoente em companhia de Ananias e Francisco, vigiando o cafezal da fazenda, e parado perto da porteira que divide o cafezal do pasto quando ali apareceu o "preto de nome Benedicto trazendo no lombo um pequeno saco de café". Interrogado, Benedicto afirmou ter tirado aquele café de um monte que se achava junto do caminho. E nessa ocasião foi preso por ele depoente e seus companheiros conduzido a fazenda e entregue ao administrador. E ainda disse o depoente que nunca havia visto o acusado antes desse dia. (...) 
$\left.3^{a}\right)$ Francisco Cerratori, com trinta e três anos de idade, casado, camarada da fazenda Matto Dentro, neste município, não sabe ler nem escrever, ser italiano.

Disse que ontem mais ou menos as oito da noite ele e mais companheiros achavam-se de ronda no cafezal da fazenda próximo a uma porteira quando apareceu "um preto com um saco de café", e sendo preso por eles vigias, identificaram-se tratar de Benedicto de Tal. E este declarou que havia trazido esse café do cafezal. O levaram, assim, para o administrador da fazenda de onde o conduziram até esta cidade. (...)

O que se apreende desses depoimentos? Como se pode interpretar um texto desses? Parece nos dizer algo sobre as relações sociais e sobre a disposição dos vários sujeitos na sociedade. Tanto a sinopse do promotor, quanto depoimento das testemunhas identificadas por italianas, referem-se a Benedicto Manuel por "preto". É mister avisar o leitor que esse termo não é ingênuo, pelo contrário, é carregado de significado. No contexto temporal e territorial que estamos a analisar esse termo, "preto", tem aparecido na documentação que pude analisar, continuamente, em situação de hostilidade, em todo tempo num tom pejorativo. ${ }^{61}$ Interessante é notar que o único depoimento que cita apenas cita o nome do acusado é o do brasileiro Ananias Porfírio da Conceição. Aliás, é o único que dá a entender conhecê-lo.

Era negro? Este é justamente o ponto falho dessa história; não posso precisar essa informação. Mas, pensando bem, que necessidade há de saber-se? Uma vez que eu diga os outros e todas as circunstâncias do acontecimento, do caso, o resto pouco importa.

Após a fala das testemunhas o delegado interrogou o indiciado. Foi-lhe perguntado o que usualmente se inquiria aos denunciados: seu nome, idade, estado civil, nacionalidade, ocupação, moradia e se sabia ler e escrever. Ao que respondeu

\footnotetext{
${ }^{61}$ Exemplo disso é que nos jornais negros os termos utilizados são sempre "negro", "mulato", "homem de cor", mas nunca preto.
} 
respectivamente chamar-se Benedicto Manoel, contando com a idade de quarenta e cinco anos, casado, brasileiro, pedreiro e residente na rua Francisco Glicério pegado ao número cento e dez, não sabendo ler nem escrever. Quando indagado se tinha ciência do motivo pelo qual achava-se preso retorquiu:

que em dias deste mês foi ele respondente, convidado em sua própria casa, em presença de Benedicto Clemente de Tal, por um seu patrício Antônio da Silva colono da Fazenda Matto Dentro, para ir na mesma fazenda ajudá-lo a colher café, ao que ele respondente não anuiu porém pela insistência de Antônio da Silva, resolveu [resolvera?] ir ajudá-lo, sendo que o primeiro dia que prestou esse serviço foi no dia onze do corrente; que trabalhou três dias na fazenda, vindo dormir todas as noites em sua casa; que no dia treze, resolveu ele respondente a não continuar mais nesse serviço pois que estava sendo prejudicado em seus salários; então, preveniu Antônio da Silva, que não continuasse mais a trabalhar, e ia para sua casa ao anoitecer ; que chegando essa hora, isto as oito da noite Antônio da Silva lhe fez presente metade de um leitão e um pouco de café em coco, que havia recebido do patrão; que posto isto dentro de um saco,ele respondente dirigiu-se ao caminho da cidade, para ir para sua casa; que ao chegar a porteira do cafezal foi ele preso pelos rondantes, que examinando o saco que trazia, disseram que o café era furtado, mas que estavam ali mesmo a espera de Antônio da Silva sobre quem havia denúncia de furto de café; que daí foi ele respondente conduzido a fazenda, e em seguida a esta cidade; que na ocasião que era conduzido preso a esta cidade, conseguiu evadir-se de seus condutores, sendo novamente preso em sua casa muito tempo depois.

Nessa resposta nada parece ser casto. As palavras de Benedito Manuel ou, mais rigorosamente, a transcrição de sua fala, efetuada pelo escrivão, assalta vários assuntos ocultos.

De pronto notemos que o defendente tinha endereço fixo. Quando o colono Antônio da Silva lhe fez convite para trabalhar para si, foi procurá-lo em sua "própria casa", não estava nessa ocasião andando na rua a esmo tampouco se encontrava num dos botequins da rua conceição... É o colono apontado como agente da ação, parte dele 
o desejo de contratar Benedicto Manuel como seu ajudante. Com essa simples afirmação, aparentemente inocente, o acusado defende-se da eiva de ocioso, ao menos em parte, pois, como veremos com mais vagar no capítulo II, esse era um dos requisitos para não sê-lo.

Benedicto Manuel habitava o centro da cidade. A rua Francisco Glicério naquele tempo, e ainda hoje, cortava o centro da cidade. De uma extremidade a outra podia se topar com endereços os mais distintos. Pela localização infere-se que o acusado estava um tanto quanto longe dos encantos e confortos das habitações mais refinadas.

Peço ao leitor que verifique algumas páginas contando desta e note a indicação que fiz junto ao mapa. O acusado declarou morar "pegado ao número 110". A indicação pouco precisa sugere que, provavelmente, tratava-se de habitação irregular, muito provavelmente alguma espécie de habitação coletiva. A rua Francisco Glicério em termos de extensão pouco mudou dessa época aos dias atuais, desse modo é possível afirmar que de onde o réu morava a parte mais nobre do centro da cidade havia uma distancia de pelo menos $2 \mathrm{~km}$.

Ainda sobre o depoimento aviso aos que ainda não notaram: nada disso, caro leitor é resposta ingênua. As redondezas havia vários botequins na Rua Conceição, entre a Barão de Jaguará e a Francisco Glicério( no mapa de 1900 a linha laranja é a rua Francisco Glicério e a vermelha a Rua conceição). O mais famoso deles ficava em frente ao Theatro Rink, mas, mais uma vez, informo o leitor que esse assunto será tratado com maior calma no capítulo próximo. Por ora é mister saber que essa região da cidade era bastante frequientada e habitada por negros. Mais uma evidencia de que a declaração de Benedicto que foi abordado pelo colono em sua própria casa expõe inquietação deste em não parecer ocioso aos olhos das autoridades. 
Com certeza eram argumentos usufruir do atributo de cidadãos de boa índole, nesse caso como pedreiro posto que ele era profissional qualificado. O segundo modo de se livrar dessa acusação parte para a idéia de que residia no centro da cidade.

Não significa que o acusado esteja mentindo, mas é certo que ele sabia o que dizer. Ele alega que foi contratado não pela proprietária da fazenda ( $\mathrm{D}^{\mathrm{a}}$ Anna Joaquina de Prado Aranha) nem pelo administrador da fazenda, que efetivamente é quem leva essa denuncia adiante, mas por um colono português. Afirma que tem um ofício regular, o de pedreiro. E a fim de ajudar o dito português se prestou a esse segundo serviço.

Interessante notar que o colono tinha liberdade para contratar alguém para lhe auxiliar em seu serviço.

Ainda sobre o depoimento aviso aos que ainda não notaram: nada disso, caro leitor é resposta ingênua.

Após o depoimento citado acima, consta no processo um documento do dia 15 de agosto em que são consultados duas pessoas para darem valor ao saco de café que supostamente havia sido furtado. Verificou-se ter quase quinze litros de café em côco o que equivalia no período a três mil e quatrocentos réis. Assinaram a folha Ignacio Ferreira de Carvalho e Carlos Bimberg [?]. Em seguida o delegado, Dr. Joaquim Gomes Pinto, encaminha o inquérito ao promotor e este, por seu turno, ao juiz Dante Soriano Filho.

No dia 18 de setembro do mesmo ano verificamos novo interrogatório. A única novidade na fala de Benedicto é que o réu declara dessa vez ser de origem baiana. E ser filho de Manoel e Vicência.

Acompanhemos mais uma vez o que declaram as testemunhas, dessa vez perante o juiz. Totalizara-se cinco ao todo. A primeira delas é João Baptista dos Santos, com trinta e dois anos, casado, brasileiro, administrador da fazenda "Matto Dentro" daquela 
comarca. É provável que o processo seja de autoria dele, uma vez que ao que tudo indica sua patroa sequer sabia da existência de tal furto, uma vez que morava em São Paulo. $^{62}$

Ao que lhe fora perguntado respondeu que na qualidade de administrador da fazenda "Matto Dentro" sabia que ocorriam pequenos furtos de café colhido, devido a queixas de diversos colonos. E assim mandou que as referidas testemunhas desse processo passassem a rondar os cafezais para apanhar o ladrão. E desse modo, a certo dia do mês de agosto (o qual não se lembrava) apanharam um rapaz com 20 litros de café e um porco regulando mais ou menos meio alqueire e lhe apresentaram o réu. Este foi preso nessa mesma noite e escapou furando o saco de café, porém fora encontrado no dia seguinte, pela manhã, em sua própria casa não tendo oferecido qualquer resistência com relação a captura. Nada pode informar com relação a conduta do denunciado pois este “além de não ser empregado dele depoente, tinha aparecido recentemente na dita fazenda, salariado por um colono." Respondendo a pergunta do advogado de defesa disse ignorar se o colono Antonio, patrão do réu fora quem lhe dera o café apreendido, porém é certo que o réu teria lhe confessado ter furtado aquele café. E o réu reafirmou que o café apreendido fora lhe dado pelo colono.

A segunda testemunha é Ananias Rufino da Conceição, com 38 anos, solteiro, brasileiro, trabalhador de roça, residente na fazenda "Matto Dentro"assim como os demais que apareceram daqui em diante. Naquela ocasião disse que em dias do mês de agosto, em cuja data não se recordava, estando a rondar conjuntamente com outras testemunhas do processo, pelo cafezal da fazenda 'Matto Dentro' do qual eram empregados, e a mandado do respectivo administrador, as 8 horas da noite mais ou menos, viram o denunciado transitar pelo cafezal com um saco, pelo que aproximando-

\footnotetext{
${ }^{62}$ Acredito que ela morasse em São Paulo já que sua certidão de óbito consta nessa cidade.
} 
se perguntou-lhe o que trazia 'no saco' respondendo-lhe o réu que 'era um quarto de cabrito':mas que não acreditando fizeram o réu entregar o saco e abrindo e ali encontrara mais de quinze litros de café em coco, pelo que chamando por um companheiro trata de prender o réu, afim de conduzi-lo a presença do administrador, mas que o mesmo réu conseguira evadir-se naquela noite, deitando o saco sobre ele depoente, mas que no dia seguinte pela manhã fora o réu preso em sua própria casa: que na dita noite o réu lhe havia confiado mais de uma vez que o café apreendido fora por ele furtado do monte de café.” O réu apenas contestou que o café e a lauda de leitoa que haviam no saco foram furtados e sim havia sido dada pelo citado colono.

Já a terceira testemunha era João Baptista de Souza Lima, com 22 anos, casado, brasileiro, administrador da fazenda. Contou que em dia do mês de agosto, cuja data não se recordava, as 8 da noite mais ou menos, estando encostado no portão da fazenda, próximo ao cafezal, fora chamado sua atenção por seus companheiros testemunhas do processo, que com ele estavam vigiando o cafezal, para a aproximação de um individuo que vinha em direção do portão carregando um saco: que ele e seus companheiros detiveram aquele individuo o qual não era outro senão o denunciado intimando-o para que declarasse o conteúdo do saco respondendo o denunciado que trazia um quarto de cabrito: mas que não tendo acreditado e havendo sido tomado o saco fora nele encontrado meio alqueire mais ou menos de café em coco, e mais uma manta de porco, tendo o denunciado confessado haver furtado aquele café, sem declarar entretanto se o tinha subtraído ao monte ou de qualquer outra parte, confissão essa que o denunciado repetiu apesar dele depoente ter prometido devolve-lo se o mesmo declarasse que o café lhe havia sido dado pelo colono Antônio, ao que ele depoente desconfiava: que o réu depois de preso havia conseguido escapar, jogando o saco contra as testemunha Ananias, mas que fora preso novamente no dia imediato, em sua própria casa, e 
finalmente que nunca vira o denunciado trabalhar na fazenda nem de modo algum conhecia antes ao fato." O réu contestou que a porteira junto a qual estava perto era próxima ao cafezal. Declara que havia uma boa distância e junto a porteira era a entrada.

O último depoimento do dia ficou por conta de Cerratori Francisco, com trinta e três anos, italiano, casado. Declarou não saber falar o português. E o juiz convocou José Oliveira para interpretá-lo. Seu depoimento segue a linha das demais testemunhas. Segundo ele, estavam a fazer vigia no cafezal em função do sumiço de pequenas quantidades de café. E assim a certa altura viram o denunciado carregando um saco às costas. Tomaram-lhe e viram que continha café. Por sua vez o denunciado declarou que havia apanhado o café no caminho. Porém o depoente não sabia precisar a conversa que ele acusado teve com seus companheiros pois que tento sido recente sua chegada da Itália ainda não compreendia bem o português mas que havia "entendido bem aquela declaração do réu". O réu contestou a informação de que havia pego café pelo caminho. A testemunha novamente confirmou o que disse uma vez que seu companheiro Paschoal Grecco achava ter escutado do que havia sido dito.

No dia 23 de setembro é ouvida a quinta e última testemunha - Moe Soares, com 30 anos, casado, brasileiro, carreiro. Nada sabia de ciência própria foi o que disse ao juiz. Sabia do ocorrido pelas próprias testemunhas. Nada traz de novo, portanto, ao processo.

Logo em seguida o juiz conduz o Interrogatório do Réu. Novamente seus dados são apresentados, porém, constam algumas novidades. O local exato de seu nascimento fora Rio Bonito, na Bahia. Habitava Campinas há quarenta e tantos anos. Pedreiro, não sabia ler, nem escrever; no tempo que aconteceu o crime estava na referida fazenda. Diz não ter motivo particular ao qual atribui a denuncia. 
Declara, enfim que era empregado do colono Antonio e que o que carregava no saco fora dado por ele e isso mesmo já havia confessado no momento da prisão. E passara por esse caminho pois é o que pegava para ir a sua casa.

Como conclusão, temos que a sentença anunciada pelo juiz assume a denuncia improcedente, uma vez que o ato não foi cometido em flagrante, logo o promotor não tinha competência para proceder do jeito que procedeu. Há também uma série de motivos técnicos da feitura do processo que o invalidava segundo o juiz.

A história narrada acima é mais do que aparenta e pretende. Ela documenta a vida de personagens anônimas e propõe, ainda que sem intenção, elementos para uma história das transformações urbanas. Há muitas questões a serem feitas e muitos detalhes reveladores. Primeiramente notemos que Benedicto Manuel, à época da confecção do processo, habitava a cidade e trabalhava no Campo. Morava à Rua Francisco Glicério. Caso o leitor, se conhece a cidade, imagine que a fazenda Matto Dentro localizava-se as margens da atual rodovia Heitor Penteado. ${ }^{63}$ Havia de andar um bocado para trabalhar. Mesmo que percorresse (e não há indicação de que isso ocorra) o caminho com auxilio de algum animal. Soma-se a isso o fato de que Benedicto é empregado de um colono português. Tinha outra ocupação e a fazia para complementar a renda.

Imagino que, mesmo com a tentativa de controle impetrada pela classe dominante para com as pessoas pobres e negras em geral, fosse compensatório para esses atores morar na cidade. Afinal, a cidade parece ser um espaço em que havia maior autonomia.

\footnotetext{
${ }^{63}$ A fazenda Matto Dentro existe como tal desde 1806. A partir de uma gleba desdobrada de sesmaria. Inicialmente suas atividades se voltaram para o açúcar e posteriormente ao café. Ela foi herdada em 1879, possuía a essa época mais de 200 escravos e grande produção.A fazenda foi vendida na década de 1950 a um intermediário que repassou imediatamente ao governo do Estado.Transformou-se em fazenda experimental, subordinada ao Instituto Biológico. Em 1982 foi tombada e alguns anos depois transformada no atual Parque Ecológico Monsenhor Emílio José Salim que abriga no antigo casarão um museu.
} 
Atrás deixei narrada a história das transformações. É simbólico na medida em que mostra como uma personagem quer se desligar do passado. Mora ao centro, é responsável por organizar o seu próprio trabalho, afinal escolhe para quem e onde trabalhara, senhor de si enfim. E por outro lado mostra como ainda era muito novo na cabeça dessas pessoas que um suspeito podia ser preso e levado a delegacia como se ele não tivesse direito e ainda fosse escravo. Contudo a atitude de levá-lo a delegacia, para que o Estado cumpra o papel disciplinarizador faz parte desse aprendizado. Desse período de adaptação, de choque e de negociação. 


\section{CAPÍtULO 2 \\ SOBRE O 13 DE MAlO E O IIIO IRABAILHO}

Vejam os leitores a diferença que há entre um homem de olho aberto, profundo, sagaz, próprio para remexer o mais íntimo das consciências (eu em suma), e o resto da população.

Toda a gente contempla a procissão na rua, as bandas e bandeiras, o alvoroço, o tumulto, e aplaude ou censura, segundo é abolicionista ou outra cousa, mas ninguém dá a razão desta cousa ou daquela cousa; ninguém arrancou aos fatos uma significação, e, depois, uma opinião. Creio que fiz um verso.

\section{I (DO MOTE)}

Esse capítulo reserva-se a discussão de dois temas. Primeiramente analiso, ainda que de maneira sucinta, o clima que havia se instaurado na cidade pouco antes e mais adiante na cidade antes do 13 de maio. Em seguida, voltamo-nos a um tema que tem sido central nos estudos que se pretendem uma história do pós-emancipação: a questão do trabalho, ou ainda, a do não-trabalho. Procurar conhecer o que pensavam os diversos sujeitos dessa sociedade, culminando com o que os protagonistas dessa dissertação pensavam de si próprios constitui os objetivos centrais deste capítulo.

Desde estudos primeiros como o de Florestan Fernandes (que afirmava que uma das consequências da não-integração do negro na sociedade pós-emancipação residia em sua não-adequação ao mercado de trabalho) à outros mais recentes, como o de Walter Fraga Filho, que argumenta possuírem os negros uma concepção de trabalho 
alternativa, consenso é que capacidade de se adaptar ao mundo do trabalho idealizado pelas classes dirigentes eram colocados em cheque.

Confio ser interessante exercício notar como o tema "trabalho", ou ainda o "nãotrabalho", aparece (ou se oculta) tanto nas decisões políticas (no sentido conservador do termo) tomadas pelas autoridades, quanto nas banalidades do cotidiano, que aparentemente é desprovido de profundidade e é desimportante. ${ }^{64}$ Mais do que precisar o grau de inserção das pessoas negras no mercado de trabalho formal (reproduzindo a lógica da classe dirigente) vale o esforço de farejar as concepções de trabalho que tinham esses sujeitos.

\section{II (OS DIAS ANTERIORES...)}

Janeiro de 1887, em seu relatório ao presidente de província, o então chefe de polícia da província de São Paulo - que, aliás, acabava de ser promovido a chefe de polícia da corte - o senhor Salvador Q. Moniz Barreto de Aragão relatou certos eventos em decorrência da crise do elemento servil. ${ }^{65} \mathrm{O}$ tom da carta é, ao mesmo tempo, orgulhoso de suas ações, mas ainda expressa sua preocupação com o escasso número de praças. E não era pra menos, segundo Aragão, numa quantidade grande de cidades os ânimos teriam se exaltado. Em Piracicaba, por exemplo, o fazendeiro Luiz Gonzaga, resolveu libertar condicionalmente dois escravos, e o fez saber "apenas" na imprensa local. Esses, ingratos, por seu turno, resolveram fugir e através da estrada de Ferro Ituana rumaram para capital. Ao chegar em Itu foram detidos e recolhidos à cadeia (haja vista

\footnotetext{
${ }^{64}$ Ensina-nos E. P. Thompson que na Inglaterra do XVIII certas atitudes das classes mais baixas, se lidas com cuidado, possuem significado político, não necessariamente revolucionário mas contestador. Acredito que isso posso servir para outros contextos, ou, ao menos, para o contexto que estamos a estudar. CF: THOMPSON, E. P. Senhores e Caçadores. Rio de Janeiro, Paz e Terra, 1987; THOMPSON, E. P. Costumes em Comum. São Paulo, Companhia das Letras, 1988.

${ }^{65}$ As informações referente à policia a seguir foram extraídas dos relatórios de chefe de província de São Paulo de 1887 à 1889 e dos relatórios ao presidente do Estado até 1906.
} 
que o proprietário dos escravos tencionava reavê-los). Poucos dias depois, esses mesmos presos, voltaram com alguns camaradas para Piracicaba, sob condução da polícia. Na cidade um grande número de pessoas se reuniu e conseguiram libertar os dois. No dia seguinte havia "mais de mil pretos" ocupando as ruas e causando desordens, e a multidão só teria sido contida quando a parte "séria" da população interveio ajudando a polícia com armas.

Notícias da população em revolta eram bastante rotineiras nos jornais. ${ }^{66}$ Talvez em escala parecida com notas de senhores que alforriaram escravos. Com efeito, quase todos os dias havia noticia de mais uma libertação. Mais certo era vencer no jogo do barão de Drummond que isso não ocorresse. Sempre um senhor, quando não dois ou mais, via-se tocado, comovido diante do drama humano daquela gente de pele escura, outros até se descobriam membro de uma família de profetas aprés coup, pos facto depois do gato morto. ${ }^{67}$ Os dois exemplos citados acima ilustram situações distintas. Na primeira o senhor, tenente-coronel Joaquim Ribeiro de Avellar, concede. Notemos que nesse jogo, entre senhor e cativo, conceder não é um termo inocente. O senhor, que é uma entidade superior por definição, está a exercer sua decisão. Ele é fonte da atividade, logo faculta. $\mathrm{O}$ ato de alforriar deve partir de seu, e somente seu, anseio. Que o senhor acreditasse nisso deveras não nos é possível descobrir (e eu confio que alguns criam) tampouco nos é relevante, mas sim que isso faz parte da sua retórica, de seu

\footnotetext{
${ }^{66}$ Vide AZEVEDO, C. M. Onda Negra, Medo Branco: o negro no imaginário das elites - século XIX. Rio de Janeiro,Paz e Terra, 1987; SCHWARCZ, L. K. M. Obra citada e MACHADO, M. H. de T. O plano e o pânico, os movimentos sociais na década da abolição. Rio de Janeiro, Editora UFRJ; São Paulo: Editora da USP, 1994.

${ }^{67}$ Refiro-me aqui a uma perspicaz crônica que Machado de Assis publicou no jornal Gazeta de Noticías para a série Bons Dias. Foi publicada em 19 de maio de 1888. Lê-se nela uma situação, cômica na qual o senhor, que escreve na primeira pessoa, liberta seu escravo Pancrácio dias antes da Princesa e gaba-se de ser ele alma muito benévola e ter concedido a liberdade a este. Para uma análise disso CF: GLEDSON, John. Machado de Assis Ficção e história. Rio de Janeiro, Paz e Terra, 1986 e CHALHOUB, Sidney. A arte de alinhavar histórias: a série A + B de Machado de Assis. In: CHALHOUB, Sidney; PEREIRA, Leonardo Affonso de Miranda; NEVES, Margarida de Souza. (Org.). História em cousas miúdas: capítulos de história social da crônica no Brasil. 1 ed. Campinas, Editora da UNICAMP, 2005. v. , p. 67 85.
} 
modo de situar-se no mundo e, informa o ordenamento das relações sociais. A leitura da segunda nota também nos é reveladora. Domingos, que é tratado curiosamente por escravo - mesmo sendo já liberto no momento da escritura da nota do jornal - pagou uma polpuda indenização ao senhor, acrescido disso ficou obrigado a prestação de serviços, provavelmente sem remuneração. Isso tudo em 1887. Quando, ao que parece, muito se falava que mais dia, menos dia, a libertação plena de todos os escravos ocorreria.

\section{Libertação em massa}

O senhor tenente-coronel Joaquim Ribeiro de Avellar, fazendeiro em Paty de Alferes, província do Rio, concedeu a liberdade a todos os seus escravos em número de 320 , desistindo ao mesmo tempo do serviço de 193 libertos sexagenários e 193 ingênuos. ${ }^{68}$

\section{Liberdade}

O escravo Domingos, pertencente ao senhor dr. Guilherme Silva, libertou-se indenizando seu senhor com a quantia de $200 \$ 000$ e ficando obrigado a prestação de serviço a terceiro, pelo espaço de ano e meio.

A respectiva carta foi registrada em nome do tabelião dr. Silva. ${ }^{69}$

Interessante notar que quem concedia a liberdade era o senhor e isso fazia parte da retórica senhorial. Esse tipo de prática talvez parecesse cômica para os leitores contemporâneos das crônicas de Machado na série balas de estalo. É válido lembrar que faz parte da retórica senhorial que quem concede a liberdade é sempre o senhor, mesmo quando ela é garantida pela lei aos sexagenários e aos ingênuos.

\footnotetext{
${ }^{68}$ Diário de Campinas, terça-feira, 15 de março de 1887.

${ }^{69}$ Diário de Campinas, sexta-feira, 4 de março de 1887.
} 
Tabela 1. Municípios da Província de São Paulo com mais de mil escravos libertos.

\begin{tabular}{|c|c|c|c|c|}
\hline Municipios & $\begin{array}{l}\text { Escravos } \\
\text { rematriculados } \\
\text { que atingiram a } \\
\text { idade de } 60 \text { anos } \\
\text { em } 20 \text { de março de } \\
1888 \text {. }\end{array}$ & $\begin{array}{l}\text { A titulo gratuito } \\
\text { e oneroso por ato } \\
\text { particular. }\end{array}$ & $\begin{array}{l}\text { Por conta do } \\
\text { fundo de } \\
\text { emancipação. }\end{array}$ & $\begin{array}{l}\text { Óbitos } \\
\text { registrados des de } \\
30 \text { de março de } \\
1887 \text { à } 20 \text { de } \\
\text { março de } 1888 .\end{array}$ \\
\hline Amparo & 23 & 1.090 & 10 & 69 \\
\hline Campinas & 19 & 4.579 & 14 & 37 \\
\hline Itatiba & 12 & 1.628 & - & 38 \\
\hline Limeira & 12 & 1.607 & 15 & 33 \\
\hline Pindamonhangaba & 45 & 1.475 & 7 & 36 \\
\hline Piracicaba & 15 & 1.557 & 12 & 20 \\
\hline $\begin{array}{l}\text { S. Carlos do } \\
\text { Pinhal }\end{array}$ & 11 & 1.657 & - & 13 \\
\hline $\begin{array}{l}\text { S. João do Rio } \\
\text { Claro }\end{array}$ & 13 & 1.595 & - & 33 \\
\hline Tiete & 2 & 1.703 & - & 5 \\
\hline Taubaté & 13 & 2.269 & - & 25 \\
\hline
\end{tabular}


Tabela 2 . Escravos matriculados na província de São Paulo de acordo com regulamento de 14 de novembro de $1885 .^{70}$

\begin{tabular}{|l|c|c|}
\hline Muricipios & Números & Valores dos escravos \\
\hline Amparo & 3.524 & $2538: 850 \$ 000$ \\
\hline Campinas & 9.986 & $6.851 .675 \$ 000$ \\
\hline Itatiba & 2.182 & $1.4955 .425 \$ 000$ \\
\hline Limeira & 2.374 & $1.667 .650 \$ 000$ \\
\hline Pindamonhangaba & - & - \\
\hline Piracicaba & 3.416 & $2.355: 150 \$ 000$ \\
\hline S. Carlos do Pinhal & 2.982 & $1.906 .450 \$ 000$ \\
\hline S. João do Rio Claro & - & - \\
\hline Tiete & 1.195 & $2.338: 200 \$ 000$ \\
\hline Taubaté & 2.668 & \\
\hline
\end{tabular}

O número de alforrias na região de Campinas (assim como no restante do Estado de uma forma geral) era gigantesco, Comparemos os dados acima com os da Província do Rio de Janeiro. A população escrava desta última era de 238.631 mil escravos em 3 de junho de 1886. No mesmo ano, quando fora feito a rematrícula, em observância da nova lei, (lei de 28 de setembro de 1885) passara a ser 76.210, logo decréscimo de $32 \%$ da população escrava. Entre a primeira marcação e a última temos que o fundo de emancipação libertou 7.522 escravos e mais 18.707 conseguiram-na por ato particular e 3.112 por ato oneroso particular. Já a província de São Paulo tinha em junho de 1885 um total de 153.270 escravos. $^{71}$ Eis que, portanto, uma questão se faz necessária, por qual motivo, o número de revoltas cresce quando as alforrias estão a alcançar tais

\footnotetext{
${ }^{70}$ As tabelas 1 e 2 apresentam dados colhidos nos relatórios de presidente de província dos anos finais do Império. Vide Relatorio apresentado á Assembléa Legislativa Provincial de São Paulo pelo presidente da provincia, exm. snr. dr. Francisco de Paula Rodrigues Alves, no dia 10 de janeiro de 1888. São Paulo, Typ. a Vapor de Jorge Seckler \& Comp., 1888.

${ }^{71}$ De fato o fundo de emancipação libertava poucos escravos. A província do Paraná libertou 174 escravos, através por esta via em 1886. Vide : Relatorio apresentado á Assembléa Legislativa do Paraná no dia 17 de fevereiro de 1887 pelo presidente da provincia, o exm. snr. dr. Joaquim d'Almeida Faria Sobrinho. Curityba, Typ. da "Gazeta Paranaense," 1887, p31.
} 
níveis? Acredito que devamos inverter a pergunta. Justamente porque as revoltas são inúmeras é que aparecem um grande número de alforrias. Uma última tentativa da matreirice senhorial tentar ter controle sobre o que já lhes parecia incontrolável.

Não é natural, nem devemos esperar, que todos os trabalhadores escravos, adquirindo a liberdade, permaneçam nos estabelecimentos agrícolas e se dediquem aos rudes serviços da lavoura. Com a modificação do sistema a fixação do salário e dos esforços d proprietário, muitos libertos poderão, embora deslocando-se das fazendas em que viveram como escravos, continuar a prestar serviços á lavoura. Creio porém, que a maior parte, pelo menos no primeiro período da libertação, fugirá ao trabalho, ócio e a vadiagem. ${ }^{72}$

Notícias especulando sobre o provável comportamento dos libertos após a escravidão também eram rotineiras. $\mathrm{O}$ exemplo acima resume com precisão as preocupações centrais das classes dirigentes Seria, o ex-escravo afeito ao trabalho?

Numa ação de tutela datada de abril de 1888 Francisco Egydio de Souza Aranha importante fazendeiro da região, desistia da tutela de uma menor, Alexandrina. ${ }^{73}$ Segundo ele, havia a essa época, libertado todos seus escravos e "desistido do serviço dos ingênuos". Os pais da menor haviam fugido, e sendo ele mui benevolente, como queria dar a entender no documento, não queria abandoná-la à míngua. Parecia que a essa altura, às vésperas da abolição, já estava bastante evidente, na cabeça dos senhores ao menos, que esse sistema não se sustentaria por muito mais tempo. Nos jornais pululavam notícias, desde pelo menos 1887, de senhores alforriando escravos em massa. Era este o último ato do paternalismo dos senhores que estava sob a égide de uma política de produção de dependentes. Ato esse que se fazia necessário, tendo em vista os conflitos que os escravos, agora com amplo respaldo popular na luta pela

72 Relatorio apresentado á Assembléa Legislativa Provincial de São Paulo pelo presidente da provincia, exm. snr. dr. Francisco de Paula Rodrigues Alves, no dia 10 de janeiro de 1888. São Paulo, Typ. a Vapor de Jorge Seckler \& Comp., 1888. p.21-22

${ }^{73}$ TJC, Ação de Tutela. Francisco Egydio de Souza Aranha, processo no 476.Campinas, 1888. 
abolição, produziam, fugindo e desorganizando a produção em várias regiões do país. Se conferirmos os dados oferecidos pelo governo para essa região, temos que a grande maioria das alforrias fora concedida pelos senhores.

Se na década de 1870 a alforria conseguida na justiça pelo escravo era signo da desestruturação do sistema, que pela primeira vez tinha a possibilidade legal de conseguir sua liberdade mesmo contra a vontade de senhor; em fins da década de 1880 a alforria era vista como a chance de o senhor ser "indenizado", por assim dizer, seja com dinheiro ou trabalho condicional. Pelo menos a partir de determinando momento as classes proprietárias passaram a ver a questão do liberto condicional como uma forma de prolongar o seu domínio sobre os mesmos e garantir a continuidade da política de produção de dependentes. ${ }^{74}$ Os senhores perdiam o controle da situação e, ao mesmo tempo, continuavam coerentes com sua política paternalista. Concediam, em grande medida, alforrias condicionais e estavam cientes de que a escravidão mais dia menos dia ruiria. Era uma forma de tentar prender o escravo à sua propriedade, ou a de terceiro e também de conseguir indenização, seja por parte do Estado com as alforrias concedidas pelo fundo de emancipação ou do próprio escravo que julgasse a modificação de seu status jurídico questão de primeira ordem. Para os escravos significava, quase sempre, conquista e o reconhecimento de que era liberto, logo, o afastamento da imagem degradante do cativeiro e a ascensão social. Para os senhores, formas de controle da população escrava.

Por outro lado para o escravo não estava exatamente claro quanto tempo deveria permanecer no cativeiro e a conquista da liberdade através da justiça poderia ainda ser

\footnotetext{
74 Joseli Mendonça demonstra que em 1885 havia uma busca por manter um gradualismo, por parte das classes dirigentes, no tocante a emancipação. A indenização estava no cerne desta discussão. De um lado tínhamos um esforço dos senhores por manterem os escravos o maior tempo possível no cativeiro e por outro uma tentativa de manter a organização social administrável. Vide MENDONÇA, Joseli. Entre a mão e os anéis: a lei dos sexagenários e os caminhos da abolição no Brasil. Campinas, Editora Unicamp: 1999.
} 
uma opção. Pode parecer ilógico que o escravo, em 1886, quando já se falava bastante do final da escravidão, estivesse disposto a gastar uma fortuna para libertar sua prole. Esse é o caso de Guilhermina, uma escrava sexagenária que queria a libertação de toda sua família ${ }^{75}$, para conseguir tal intento utilizava um argumento relativamente simples: tendo chegado ao país depois de 1831 sua escravidão teria sido ilegal, assim como de todos seus descendentes. Pode não parecer lógico, num primeiro momento, mobilizar um número tão grande de documentos e gastar grande parte de suas economias com a compra da liberdade de sua família, com a escravidão parecendo ser tão eminente. Eric Foner, analisando o caso americano, nos convida a pensar como a liberdade era valorizada pelos escravos, mesmo que o presente lhes parecesse tenebroso em certo sentido. ${ }^{76}$ Mas isso pode ser apenas aos nossos olhos. Talvez para o escravo fosse, mesmos em 1886, algo incerto apesar do movimento abolicionista e das mudanças na lei. Tão incerto ao ponto de muitos indivíduos não apenas disporem de grandes encargos financeiros, mas também mobilizaram apoio de terceiros como curadores e advogados para garantir a liberdade dos seus. ${ }^{77} \mathrm{O}$ que demonstrava por um lado que as coisas não estavam ainda resolvidas de cima para baixo e por outro lado que os próprios escravos não deixaram que a emancipação fosse prerrogativa senhorial, que tomaram para si e por si mesmos a sua realização.

\section{III (O DIA SEGUINTE...)}

Há uma cena nos jornais post factum que se repete tão insistentemente a ponto de inaugurar, vitoriosamente e por meio dessa repetição, a idéia que se tem comumente de

\footnotetext{
${ }^{75}$ Vide a transcrição da carta em Anexos.

${ }^{76}$ FONER, Eric. Nada além da liberdade: a emancipação e seu legado. Rio de Janeiro, Paz e terra, 1988.

${ }^{77}$ Vide AZEVEDO, Elciene. Obra citada.
} 
que a abolição foi dádiva. Idéia essa que perdeu sua força no meio acadêmico já algum tempomas não em outros meios. À sua época foi esse episódio encenado dramaticamente nas páginas dos jornais e periódicos e, talvez, seja daí que ela derive. Publicações importantes como, por exemplo, a Revista Ilustrada que ofereceu, aos seus leitores, edição especial a respeito do ocorrido e a nós, cento e vinte e dois anos depois, a dimensão da euforia e o sentimento de nacionalidade exacerbada que teria comovido a todas as classes.

Na edição imediatamente posterior ao treze de maio da referida publicação notamos, logo na capa [figura 2.1], que a abolição é, ao mesmo tempo, momento de doação e reafirmação do exercício de autoridade. Sendo o segundo consequencia do primeiro.

Vale ressaltar que em se tratando de Agostini nada é sem propósito. ${ }^{78}$ Assim como suas escolhas seus silêncios informam sobre seu posicionamento político; mais do que isso, permite entendermos como, na interpretação do autor, esse momento tão ímpar foi recepcionado pelas mais diferentes personagens.

Notemos que nessa gravura, no alto da composição há dois escudos com datas importantes na luta abolicionista, marcos do processo de emancipação (naturalmente para aqueles que a concebem como processo). ${ }^{79}$

\footnotetext{
${ }^{78}$ Angelo Agostini foi um dos maiores caricaturistas brasileiros do século XIX. Vide BALABAN, Marcelo. Poeta do Lápis: A trajetória de Angelo Agostini no Brasil Imperial - São Paulo e Rio de Janeiro - 1864-1888. Tese (Doutorado em Históra), IFCH, UNICAMP, Campinas, 2005.

${ }_{79}$ Conhece o leitor a essas leis? A primeira, a de 1831, foi aquela que na teoria proibiu o tráfico de escravos para o Brasil, mas na prática era "para inglês ver", pois, como é sabido, continuaram a entrar escravos no país até que em 1850 uma outra lei regulando o fim do tráfico entrou em vigor. E dessa vez sim a valer. Contudo, a lei de 1831 não chegou a ser anulada. Supõe-se que se ocorresse o reconhecimento de que em algum momento ela esteve em vigor todos os escravos chegados após sua regulamentação seriam dados por livres.

A segunda, conhecida vulgarmente por lei do ventre livre, tinha um dispositivo mais importante que o que se pensa comumente. $\mathrm{O}$ ponto mais polêmico dessa lei consistia no fato de conter um dispositivo que permitia ao escravo conseguir libertar-se mediante a apresentação do pecúlio. Logo não cabia mais ao senhor libertá-lo ou não mediante pagamento.
} 
Ao centro há um Arlequim que, naturalmente, é o comandante dos festejos. Sua simbologia pode ser vista como irônica. Há ainda dois acompanhantes, cujas faces emergem da penumbra. O primeiro empunha uma bandeira do Império e a finca sob um estandarte onde é reproduzido o texto da sucinta lei de treze de maio. É a figuração do Império como condutor do processo. Os nomes de José do Patrocínio, Joaquim Nabuco, Senador Dantas e João Clapp aparecem enfileirados junto à lei. Indicando de quem para o artista foram os nomes responsáveis e digno de lembrança pela façanha. Na porção inferior do quadro vê-se que toda a classe de pessoas é um tanto quanto limitada: todos são brancos e tem chapéus a tira-colo. Não se vê um misero ex-escravo, justamente aquele a quem mais deveria interessar os afamados festejos. 


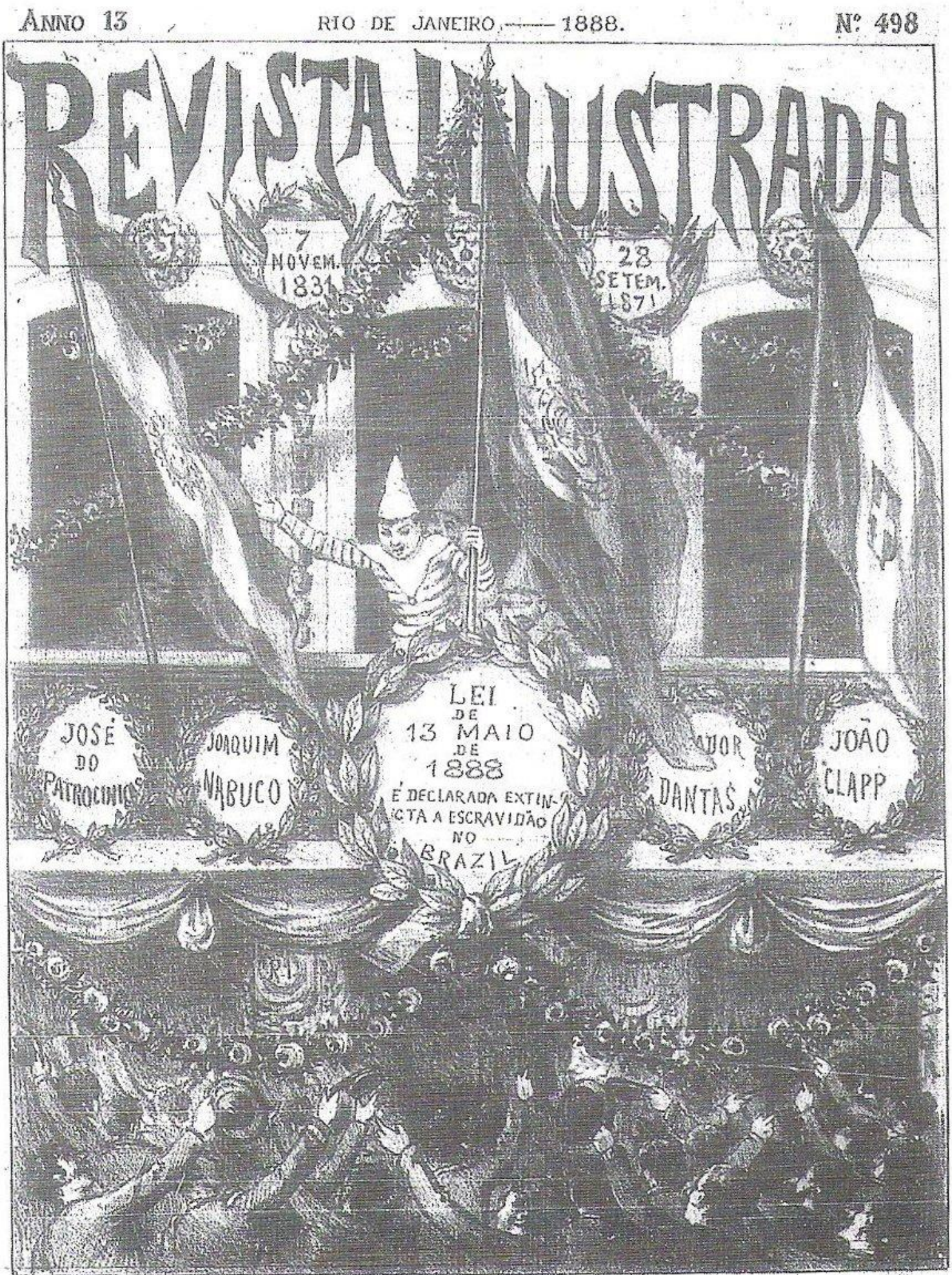

A Revista dirrante os feslejos commzemzorativos da Alboliçäo.

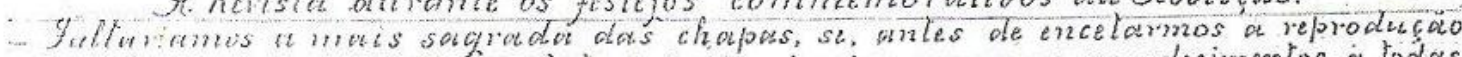

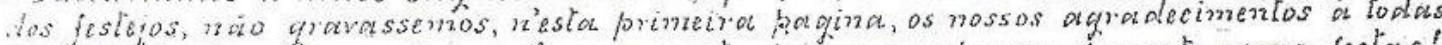

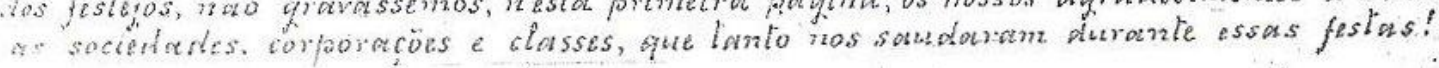

\section{Revista Ilustrada,}


Esse clima de autoglorificação nacional contrastava com algo que, quase simultaneamente, acontecia na câmara dos deputados: o debate sobre a lei de repressão à ociosidade. ${ }^{80}$ Proposto pelo ministro Ferreira Vianna, entrou em discussão em julho de 1888 e foi aprovado quase que por unanimidade, e não sem razão (como nada que acontece nessa casa). Tal projeto surgiu como resposta às reclamações, por vezes exaustivas e visivelmente exageradas, dos deputados a respeito da desordem e balburdia que o 13 de maio havia acirrado. Não exatamente com relação aos festejos, mas sua preocupação com a desorganização do trabalho.

Antes do referido evento muito se discutiu na imprensa o provável comportamento dos recém egressos após a escravidão. E as mais diversas teorias foram postas no papel. Haja vista que, diferentemente da leis abolicionistas essa, da noite para o dia, igualara todos os cidadãos juridicamente. Talvez até tivesse instituído a idéia de cidadão. É provável que se perguntassem se o ex-escravo seria afeito ao trabalho.

Devemos, antes de qualquer coisa, ter em mente que o conceito de trabalho que os senhores tinham é apenas mais um. Muito diferente daquele dos trabalhadores, como veremos daqui em diante.

\section{IV (DOS PROCESSOS)}

Para Campinas encontrei ao todo 14 processos de vadiagem no recorte escolhido. Um número relativamente pequeno, principalmente se atentarmos para o que ocorria com cidades de grande porte como o Rio de Janeiro.

Esse tipo de fonte está no centro da discussão, uma vez que contêm depoimentos interessantes de pessoas em diferentes situações e posições sociais a respeito do mundo do trabalho e da organização social.

80 Para uma analise de maior fôlego sobre o debate vide CHALHOUB, Sidney. Trabalho, Lar e Botequim. Obra citada. 
Sabemos pela leitura dos processos, e pelas estatísticas extraídas dos jornais, que o movimento na prisão era muito maior. ${ }^{81}$ Só no primeiro semestre de 1905 , em média mais de 30 prisões por vagabundagem e 40 por embriaguez foram efetuadas. ${ }^{82}$ Para efeito de comparação, segundo consta na mensagem ao presidente da província de 1907, na Capital, apenas no primeiro semestre 220 processos foram abertos e concluídos. ${ }^{83}$

Tabela 3. Processo por embriaguez e vadiagem, 1898-1910.

\begin{tabular}{|l|c|c|c|c|c|c|}
\hline \multicolumn{1}{|c|}{ Réu } & Autor & Ação & Ano & Ofício & Caixa & Processo \\
\hline \hline ALFREDO SANTOS & $\begin{array}{l}\text { JUIZO MUNICIPAL } \\
\text { CAMPINAS }\end{array}$ & VADIAGEM & 1909 & 4 & 284 & 6551 \\
\hline \hline CANDIDO MACHADO & & EMBRIAGUEZ/VADIAGEM & 1907 & 99 & 19 & 287 \\
\hline $\begin{array}{l}\text { DOMINGOS } \\
\text { PENTEADO ET AL }\end{array}$ & $\begin{array}{l}\text { JUIZO MUNICIPAL } \\
\text { CAMPINAS }\end{array}$ & VADIAGEM & 1898 & 3 & 511 & 9851 \\
\hline $\begin{array}{l}\text { EUCLIDES XAVIER } \\
\text { SANTOS }\end{array}$ & EMBRIAGUEZ/VADIAGEM & 1907 & 99 & 20 & 290 \\
\hline $\begin{array}{l}\text { EUCLIDES XAVIER } \\
\text { SANTOS }\end{array}$ & $\begin{array}{l}\text { JUIZO MUNICIPAL } \\
\text { CAMPINAS }\end{array}$ & VADIAGEM & 1908 & 1 & 406 & 7316 \\
\hline $\begin{array}{l}\text { EVA MARIA } \\
\text { CONCEICAO }\end{array}$ & EMBRIAGUEZ/VADIAGEM & 1907 & 99 & 20 & 292 \\
\hline $\begin{array}{l}\text { EVA MARIA } \\
\text { CONCEICAO }\end{array}$ & VADIAGEM & EMBRIAGUEZ/VADIAGEM & 1910 & 99 & 30 & 458 \\
\hline $\begin{array}{l}\text { FIRMINO JOSE } \\
\text { MATTOS }\end{array}$ & $\begin{array}{l}\text { JUIZO MUNICIPAL } \\
\text { CAMPINAS }\end{array}$ & VADIAGEM - EMBRIAGUEZ & 1907 & 4 & 273 & 6365 \\
\hline $\begin{array}{l}\text { FRANCISCA MARIA } \\
\text { SILVA }\end{array}$ & EMBRIAGUEZ/VADIAGEM & 1907 & 99 & 21 & 308 \\
\hline \hline \begin{tabular}{l} 
JOSEFA BENEDICTA \\
\hline JUVENAL CRUZ
\end{tabular} & $\begin{array}{l}\text { JUIZO MUNICIPAL } \\
\text { CAMPINAS }\end{array}$ & EADIAGEM - EMBRIAGUEZ & 1908 & 3 & 518 & 9925 \\
\hline $\begin{array}{l}\text { JUVENCIO CAMARGO } \\
\text { E SILVA }\end{array}$ & EMBIAGUEZ/VADIAGEM & 1907 & 99 & 21 & 312 \\
\hline $\begin{array}{l}\text { PAULO CATTANI } \\
\text { JESUS }\end{array}$ & EMBRINOCENCIAGUEZ/VADIAGEM & 1907 & 99 & 22 & 331 \\
\hline SEBASTIAO OLIVEIRA
\end{tabular}

${ }^{81}$ Ainda na delegacia quando se produz o inquérito, o delgado pede para que o carcereiro verifique quantas vezes o réu foi preso. Em geral já haviam sido presos muitas vezes e era cosia que se definia na delegacia com uma noite na prisão e soltos no dia seguinte.

${ }^{82}$ MACIEL, Cleber. Discriminações raciais: negros em Campinas 1888-1926. Campinas, Área de publicações/ Centro de memória UNICAMP, 1996.p. 182. Há de se observar que o autor não computou no quadro as prisões efetuadas sob o nome de vadiagem aparentemente por serem poucas

${ }^{83}$ Mensagem do presidente da província à Assembléia legislativa do estado de São Paulo de 1907. p.341. 
Como se pode ver na Tabela 3, excetuando-se um processo de 1898, todos os demais se concentram entre os anos de 1907-1910 chegando a seu pico em 1907-1908. Uma questão para se pensar é porque essa concentração? Os de 1907 começam mais ou menos ao mesmo tempo entre fevereiro e março. Pensemos na figura do delegado da comarca. Nesse período era o sr. Dr. Evaldo Bandeira de Mello. Na hierarquia da policia significava que era delegado da $2^{\mathrm{a}}$ classe hierárquica provavelmente. Era responsável pela comarca, e se o secretario de justiça e segurança publica o autorizasse, também de outros municípios que compunham a comarca.

Ainda sobre as características dos processos. Em apenas um não consegui identificar a cor do réu. ${ }^{84}$ Há apenas dois em que vemos brancos como réus.

Ao fim do Império começaram as discussões sobre a organização da polícia. No período de transição do Império para republica foi conservada a força policial do regimento anterior. A organização desta continua a ser decidida por cada estado. Entretanto, os chefes de policia continuavam a ser nomeados pela união. A policia do estado de São Paulo passou a contar com um efetivo relativamente maio passando de 1500 para 1700 praças. Segundo o relatório do chefe da província de 1890, a única área onde houve conflito foi o porto de Santos. ${ }^{85}$

Em 1896 a policia passou a ser organizada de maneira diferente com a lei 491 de 29 de dezembro de 1896. Passou a ser organizada em torno de duas grandes divisões: a brigada policial e a guarda cívica. A primeira era a guarnição militar do estado. Possuía três corpos de infantaria. Eram 89 oficiais 123 inferiores e 2196 praças; Além do corpo de bombeiros com 17 oficiais, 18 inferiores e 333 praças. A guarda cívica funcionava na Capital. Contava com 2 oficias, 100 praças e num total 2.883 de força policial na

\footnotetext{
${ }^{84}$ Trata-se do primeiro processo datado de 1898 . Alias é o único que se passa na área rural.

${ }^{85}$ Sobre a organização da polícia no Brasil republicano conferir BRETAS, Marcos Luiz. Obra citada; SOUZA, L. A. F. de. Poder de polícia, Policía Civil e práticas policiais na cidade de São Paulo (18891930). Tese (Doutorado em História), FFLCH-USP, São Paulo, 1998 e ROSEMBERG, André. Obra citada.
} 
capital. A policia de Campinas e Santos saíam da brigada policial. A guarda cívica do interior contava com 32 oficiais, 106 inferiores e 2160 praças. Totalizando assim um efetivo policial do Estado de 5.178 praças. $^{86}$

\section{V (SOBRE A VADIAGEM)}

Há uma crônica de Machado de Assis, produzida alguns dias após o 13 de maio, que capta a sinergia desse momento de forma muito arguta. Nela vemos uma situação, aparentemente cômica, em que o senhor "liberta" seu escravo Pancrácio dias antes da abolição, quando esta já fosse certa, e ainda se gaba de sua alma mui benevolente:

Por isso digo, e juro se necessário fôr, que tôda a história desta lei de 13 de maio estava por mim prevista, tanto que na segunda-feira, antes mesmo dos debates, tratei de alforriar um molecote que tinha, pessoa de seus dezoito anos, mais ou menos. Alforriá-lo era nada; entendi que, perdido por mil, perdido por mil e quinhentos, e dei um jantar.

Para além do efeito cômico que a crônica provoca nela é possível avistar os últimos suspiros de uma classe senhorial que agonizava. A questão da dádiva e da gratidão se faziam presentes. No imaginário senhorial libertar escravos antes da lei de abolição era em primeira instância fazer valer a sua vontade, como aparece na epigrafe. Tais reclamações fundam-se, portanto, nas dificuldades que os senhores enfrentavam para negociar com os escravos sua permanência nas fazendas após abolição. ${ }^{87}$

Essa lei ameaçava a ordem na medida em que igualava as pessoas, delegava aos escravos o direito de ser dono de sua força de trabalho o que antes era tido por

\footnotetext{
${ }^{86}$ Dados extraídos de Mensagem do presidente de província Campo Salles ao legislativo em 7 de abril de 1897. p.98.

${ }^{87}$ MATTOS, H. M. \& RIOS, A. L. In Quase cidadão. Obra citada.
} 
propriedade. Não é que os escravos se vissem como coisa, mas juridicamente era esse o seu status. Até aquele momento o único direito que o escravo havia adquirido, e de certa forma veladamente, fora a possibilidade de se alforriar a partir da lei de setembro de 71, mediante apresentação de pecúlio. ${ }^{88}$

O tema da vadiagem já foi explorado na historiografia brasileira em algumas oportunidades. Há trabalhos preocupados em denunciar a política repressiva e ordenadora do Estado, que através de um discurso baseado num suposto pensamento científico tomava decisões unilaterais a serviço das classes dominantes, assim como focalizaram outros enredos no sentido de entender a lógica dos subalternos, suas formas de negociação e maneiras de se posicionar politicamente. ${ }^{89}$

Façamos o breve exercício de acompanhar um trecho do famigerado debate para que o leitor tenha idéia do que se passava na cabeça dos ilustres deputados. Mais do que preocupante é revelador.

O projeto da lei era bem claro quanto a quem se estava dirigindo. $\mathrm{O}$ excerto a seguir é uma fala do deputado Mac-Dowell, resume com precisão a idéia do afamado projeto:

Votei pela utilidade do projeto, convencido, como todos estamos, de que hoje, mais do que nunca, é preciso reprimir a vadiação,a mendicidade desnecessária, etc. [...] Há o dever imperioso por parte do Estado de reprimir e opor o dique a todos

\footnotetext{
${ }^{88}$ Sobre a lei de setembro de 1871, popularmente tida por ventre -livre vide MENDONÇA, Joseli. Entre a mão e os anéis. Obra citada. Esse texto é particularmente interessante na medida em que analisa não apenas a política vista de cima como o que acontecia no nível das fazendas, sobretudo as da região de campinas.

${ }^{89}$ Esse é o caso, por exemplo, de trabalhos como o já citado Trabalho, Lar e botequim de Sidney Chalhoub. Esse autor constrói uma análise baseada na leitura de processos criminais de homicídio, na primeira década do século XX. Ele apresenta rastros da conexão existente entre a vadiagem e a pobreza, sobretudo pelo alarde em torno ao combate às classes "perigosas". Mais recentemente tem aparecido uma historiografia que se não nega essa primeira, avança na discussão na medida em que enfoca menos a repressão e se ocupa mais em entender a lógica que regia os sujeitos em questão, é esse o caso do trabalho de Walter Fraga Filho. CF. CHALHOUB, Sidney. Trabalho, Lar... Obra citada. FRAGA FILHO, Walter. Mendigos moleques e Vadios na Bahia do Século XIX, São Paulo, HUCITEC/EDUFBa, 1996
} 
os vícios que o liberto trouxe de seu antigo estado, e que não podia o efeito miraculoso de uma lei fazer desaparecer, porque a lei não pode de um momento para outro transformar o que está na natureza.

[...] a lei produzirá os desejados efeitos compelindo-se a população ociosa ao trabalho honesto, minorando-se o efeito desastroso que fatalmente se prevê como consequiência da libertação de uma massa enorme de escravos, atirada no meio da sociedade civilizada, escravos sem estímulos para o bem, sem educação, sem os sentimentos nobres que só pode adquirir uma população livre e finalmente será regulada a educação de menores, que se tornarão instrumentos do trabalho inteligente, cidadãos morigerados, [...] servindo de exemplo e edificação aos outros da mesma classe social. ${ }^{90}$

Dentre as várias possibilidades de análise quero chamar a atenção para um aspecto sui generis. Como é possível notar, a principal preocupação reside em transformar o liberto em trabalhador. O liberto era, por excelência, ocioso, vicioso e incapaz de se adaptar, sem a intervenção da lei, ao mundo dos livres. Mais do que combater a vadiagem estava em pauta um projeto de condicionamento disciplinar desses sujeitos. Havia a necessidade de pedagogicamente produzir indivíduos que atendessem a certo padrão de comportamento, conveniente à sua nova condição. Seria esse, portanto, um sujeito diferente daquele que a escravidão criara. Contudo, é certo que havia aqueles que defendiam a repressão pura e simples assim como os que acionavam outros mecanismos de controle e de educação dos ex-escravos. ${ }^{91}$

Por outro lado, esses vícios eram vistos como a expressão da negação do liberto em ser condicionado. No Brasil do século XIX um liberto poderia optar por vivenciar sua liberdade justamente negando aquilo que seria a moral da economia, do ponto de vista escravista. Logo o não-trabalho regular e itinerante era uma forma de se ver fora

\footnotetext{
${ }^{90}$ Anais da Câmara dos Deputados, 1888, vol. 7, pp.259-60. Apud: CHALHOUB, Sidney. Trabalho, Lar e Botequim. Obra citada.

${ }^{91}$ Um bom exemplo disso é a escolas de formação de domésticas estudada por Olívia Gomes da Cunha. Segundo essa autora "formou-se uma consciência moral e pedagógica do trabalho doméstico no Rio de Janeiro nas últimas décadas do XIX", articulada a representações do pós-emancipação diversas. Vide CUNHA, O. G. da. "Criadas para servir: domesticidade, intimidade e retribuição". In: Quase-cidadão: histórias e antropologias da pós-emancipação no Brasil. Rio de Janeiro, Editora FGV, 2007.
} 
do sistema de relação senhor escravo. ${ }^{92} \mathrm{O}$ fato do deputado utilizar o termo liberto para um sujeito que já não é mais escravo (pois termos como liberto e ingênuo já não eram juridicamente aplicáveis) corrobora ironicamente seu argumento de que as leis não mudavam os costumes da noite para o dia.

Mas aqui estamos a tratar apenas de idéias. Entre um projeto de lei e sua efetiva aplicação nas ruas há um hiato. ${ }^{93}$ Dentre políticas de repressão do governo certo é que a intensificação da perseguição a vadiagem era das mais recorrentes. Acompanharemos, a partir deste ponto, alguns processos envolvendo ações de contravenção de vadiagem, embriaguez para que possamos, se não responder, ao menos fazer pensar sobre como os ditos vadios se pensavam o que pensavam de serem qualificados como vadios e que percepção apresentavam dos preconceitos sociais que o restante da população tinha com relação a eles.

\section{VI (OS SENTIDOS DE SER VADIO)}

Como mencionei há três páginas, na Campinas das primeiras décadas do século XX pessoas eram detidas aos montes sob acusação de vadiagem. Mas o que significava vadiagem?

O código penal de 1890 oferece a seguinte definição:

deixar de exercitar profissão, ofício, ou qualquer mister em que ganhe a vida, não possuindo meio de subsistência e domicílio certo em que habite, prover à subsistência por meio de ocupação proibida por lei e manifestamente ofensiva da moral e dos bons costumes. ${ }^{94}$

\footnotetext{
${ }^{92}$ FRAGA FILHO. Walter. Mendigos, moleques e vadios. Obra citada.

${ }^{93}$ Rosemberg quebra com a idéia da polícia como braço armado do Estado na medida que mostra quão heterogêneo podia ser esse grupo. ROSEMBERG, André. Obra citada.

${ }^{94}$ Código Penal Brasileiro (Decreto n. 847 de 11 de outubro de 1890) comentado por Affonso Dionysio Gama. São Paulo: Saraiva e Cia. Editores, 1923.
} 
Entretanto, ao atentarmos para os processos vemos uma quantidade de versões sobre o que significa ser vadio, é relativamente vasta. Se realizarmos o exercício de comparar o que a lei estipulava como sendo o comportamento típico do vadio, e sua aplicação pela polícia e posteriormente a interpretação da justiça, veremos que há um descompasso. Isso se complica ainda mais quando nos perguntamos o que os denunciantes entendiam por vadiagem, e o que os acusados entendiam pelo termo. Acompanhemos o exemplo que se segue.

\section{VII (CLASSES PERIGOSAS...)}

Romeu do Nascimento, preto, com dezessete anos, solteiro, nacional, empregado, morador a rua Doutor Quirino número cento e oitenta e sete, sabendo ler e escrever. Aos costumes disse nada. Prestou compromisso e disse: que há seis meses, mais ou menos, conhece o acusado e nunca o viu trabalhar, pois o mesmo passa dias consecutivos na venda onde o depoente é empregado, à Rua General Carneiro número setenta e três; que o acusado vive habitualmente embriagado; que, finalmente, ouviu dizer que o acusado é gatuno, e que por esse motivo tem tido diversas entradas no xadrez da polícia. Nada mais disse. ${ }^{95}$

A passagem acima resume com perfeição as características atribuídas aos vadios. O não-trabalho regular, a embriaguez habitual, e a prática de um crime. Atentemos que a condição para se prender um vadio era o flagrante. Essa era a prerrogativa para deter e manter preso alguém que não havia cometido um crime, mas que, na visão dos delegados, estava prestes a cometer.

\footnotetext{
${ }^{95}$ TJC, Processo policial, contravenção do art 396 e 399. do código penal. Réu Firmino José Mattos, 12 de agosto de 1909.
} 
É válido ressaltar que vadiagem e embriaguez não eram, e ainda não são, crimes, mas contravenções. A definição jurídica de contravenção reside em prática de ato ilícito menos importante que o crime, nesse caso punido com prisão simples.

1907 e 1908 são os anos com maior concentração de processo de embriaguez e vadiagem, como vimos na Tabela III. Fato esse talvez esteja relacionado com o delegado querer "mostrar serviço", haja visto que a polícia de carreira estava sendo implementada no período. E também pode ter a ver com a situação precária em que se encontrava a cadeia de Campinas. ${ }^{96}$

O vadio mais conhecido de Campinas, segundo o delegado Bandeira de Mello, era Juvêncio de Camargo e Silva, popularmente chamado de Carioca (embora tenha nascido em Florianópolis) ou "Pé-espalhado", em função de uma enfermidade. Quando interrogado na delegacia, na oportunidade em que fora detido, afirmou que não trabalhava por ser homem doente, que era verdade que bebia um pouco, porém nunca fez desordem nem viveu promovendo escândalos, como afirmavam de forma contundente as testemunhas. Fora preso na Rua General Osório, enquanto estava no “Mata Fome”. [Linha Marron do mapa de 1900].

Resolvi citar esse processo justamente pela sua peculiaridade. Diferente do anterior, nesse caso em específico não pude precisar a cor do individuo, embora as testemunha sejam todas indicadas como brancas. Essa informação nos escapou nesse processo. Todavia considerando que o Mata Fome era tido como um bar "mal freqüentado" por pretos e mulatos (essa informação aparece em outros processos) é provável que Juvêncio, freqüentador de tal estabelecimento, também o fosse.

\footnotetext{
${ }^{96}$ Sobre a cadeia de Campinas temos que o prédio da cadeia agregava varias atividades. "Além de servir às sessões da Câmara e às atividades judiciais e policiais, o prédio abrigou também serviços públicos díspares, como um matadouro de animais; um açougue para a venda da carne e uma das duas escolas públicas de ensino primário para meninos que existiam na cidade, a Escola Régia." Ver LAPA, J. R. do Obra citada. Apud ABRAHÃO, Fernando. "O ajustar das contas, uma análise dos discursos sobre o sistema carcerário em Campinas na virada do século XX”. Disponível em www.centrodememoria.unicamp.br., acessado em jun.2010.
} 
Os argumentos utilizados por Juvêncio nos leva a crer que o acusado sabia o que as autoridades entendiam como sendo o comportamento considerado vicioso e maléfico, haja vista que os rebate com os argumentos citados acima. Justifica o não trabalho por sua condição física (que parece proceder tendo em vista sua alcunha) e coloca sua embriaguez em segundo plano.

No caso dos homens a vadiagem era associada, invariavelmente, a um delito. Além da questão da embriaguez, que levava as pessoas a promoverem escândalos e chocarem os homens de bem dessa sociedade, havia outras coisas que preocupavam as autoridades. No caso dos homens o furto seria consequiência mais ou menos direta, para as mulheres a libertinagem, que poderia desembocar na prostituição. Ao mesmo tempo, temos que o não-trabalho podia significar não sujeição para alguns dos ditos vadios e o trabalho regular atestado da degradação do passado escravista. Posto que, historicamente, aquele que trabalhava era desqualificado socialmente. Um caso que exemplifica isso bem é um processo de conflito de terras no qual os fazendeiros entraram com uma ação alegando estarem sendo furtados por seus vizinhos. Os referidos vizinhos trabalhavam, segundo os fazendeiros, no máximo um ou dois dias por mês, numa clara referência à suposta vadiagem dos mesmos. ${ }^{97}$

Como pudemos notar no primeiro capitulo a idéia de vadiagem serve como argumento para desqualificar o sujeito socialmente. Havia aqueles, como no caso de Benedicto Manuel, citado no último capítulo, que buscavam afastar de si a imagem de vadios. Contudo haviam aqueles que apresentavam sentidos alternativos ao termo.

Para o delegado Bandeira de Mello me parece claro que entende o não-trabalho como foco potencial de desordem. E entenda o leitor por desordem certa confusão espacial, ou seja, pessoas que não deveriam freqüentar certos espaços estarem fazendo-

\footnotetext{
${ }^{97}$ Domingos Penteador Et. Al. 1898, vadiagem.
} 
o, a revelia. Daí a constante presença da polícia nas imediações do teatro Rink, como mencionei anteriormente.

O caso de Benedicto Manuel deixa claro que o fato do ex-escravo viver para si incomodava. Ele é emblemático na medida que ilustra uma situação em que o sujeito, claramente, escolheu um caminho que passa pelo trabalho. Contudo haviam aqueles que claramente faziam outras opções. É o caso de Eva Maria da Conceição, que veremos mais adiante. Seu caso é bastante interessante, contudo tão interessante que um sub-item virou capitulo. Antes de mudarmos de capítulo faço mais um subtítulo a fim de esclarecer o que vimos até aqui.

$* * *$

Até aqui pudemos observar que diversos sentidos para vadio eram acionados. Numa leitura a contrapelo, do ponto de vista daqueles que criaram a lei de repressão, vadio era aquele que não queria se sujeitar a uma lógica de trabalho capitalista: que não estava disposto a se sujeitar a determinadas condições de trabalho, e muito menos abrir mão de algum tipo de lazer. Para escapar a esse controle, quando no tribunal, o sujeito devia acionar mecanismos que o afastassem da imagem do cativeiro. Na década final do XIX, uma das formas de demonstrar aversão pelo trabalho feitorizado passava pela idéia de trabalho, de ter uma ocupação fixa. Conforme avançamos no tempo ser letrado era também uma forma de angariar pontos para que fossem levados mais a sério do que habitualmente.

Se para os homens ser vadio estava necessariamente associado ao não-trabalho e por conseguinte a idéia de classes perigosas e ao furto, com relação as mulheres a vadiagem aparece relacionada a outro tipo de questão. 


\section{CAPÍtulo 3}

\section{SOBRE AS MULHERES}

\section{I (CONSIDERAÇÕES INICIAIS)}

É certo que até o momento pouco falei das mulheres de maneira mais específica. Apenas nas últimas páginas do capítulo anterior. Não discuti com muito empenho problemas que as vezes saltaram aos olhos. Mas por uma boa razão. Me parece pertinente dedicar a essas um capítulo inteiro. Meu propósito é entender que lugar é esse que essas mulheres ocupam numa sociedade da qual elas eram duplamente excluídas, a primeira por serem negras e a segunda por serem mulheres.

Nas páginas do Getulino (mais uma vez no Getulino) encontramos além dos recados às moças e aos seus pais de como estas deveriam se portar, há até a existencia de um concurso de beleza negra. Contudo, como se comportavam as moças negras pobres é o assunto deste capítulo. Continuemos do ponto que parei.

\section{II (SOBRE AS FONTES)}

Chamava-se Benedicta da Silva, preta, de dezenove anos, solteira, nacional, copeira, moradora à rua Duque de Caxias número vinte e quatro, sabendo ler e escrever. Quando foi a delegacia alegou que seu ex-noivo, José Amancio dos Santos, a deflorara e, como 
era de praxe, exigia reparo. Á época do ocorrido o pai de Benedicta, Geraldo da Silva, já era falecido. Fora carpinteiro. Sua mãe, Eva Maria de Jesus, era ainda viva, não se sabe sua ocupação. ${ }^{98} \mathrm{Na}$ certidão de nascimento, que foi transcrita e anexada ao processo, ainda agenda que os padrinhos foram Mario e Eva. ${ }^{99}$ Quanto a seus avós; os paternos eram Leopoldino João da Silva e Delfina de Jesus, e os maternos Calisto e Delfina, todos já falecidos à época. Logo em seguida, na certidão de nascimento ainda, uma frase saltou-me aos olhos: “todos acima libertos”[Grifo meu]. É conveniente notar que Benedicta nasceu em 1890. Isso é sugestivo do status que as pessoas negras ocupavam nessa sociedade. É simbólico. Não se trata de um ato falho do escrivão. O uso deste termo era recorrente nas certidões de nascimentos nos anos imediatos ao fim da escravidão. Tanto para descrever os pais, portanto ex-libertos e ex-escravos quanto a seus filhos. ${ }^{100}$ Significa, portanto, que a "cor" ainda era nesse momento referência a um passado cativo próximo ou remoto.

\section{III (DA « COR »)}

Já mencionei a questão da cor na ocasião da discussão de um caso no primeiro capítulo. Contudo, parece pertinente voltar ao assunto. Em pesquisa já clássica sobre o Rio de Janeiro, Hebe Mattos aponta que na região estudada por ela, assim como em outras partes da Afro-América, a indicação de "cor" desaparece dos registros históricos no pós-emancipação. No caso carioca ainda no XIX, jaz um silêncio. A ausência da "cor” é

\footnotetext{
${ }^{98}$ Como não consta tal informação é bem provável que fosse dona de casa.

${ }^{99}$ Era comum esse tipo de procedimento quando se tratava de defloramento posto que esse só se caracterize como tal se a vitima for menor de idade. Logo teria de ter menos de 21 anos.

${ }^{100}$ Hebe Mattos aponta para isso no Rio, assim como Walter Fraga Filho para o caso baiano afirma que para os anos iniciais pós-emancipação as pessoas libertadas com a lei áurea eram chamadas pela polícia de "os 13 de maio". Em certa medida são fenômenos parecidos que indicam que as mudanças, se é que elas ocorreram, não foi do dia para noite e que a associação dos negros com a escravidão continuava presente, ao menos nesses dois contextos. Vide FRAGA FILHO, Walter. Mendigos, moleques. Obra citada.
} 
acentuada tendo em vista que ao longo do XIX, ao menos para o caso carioca, esta vai se esvaindo dos registros oficiais, o que não constitui um problema para o historiador tendo em vista que seu status jurídico era indicado. O período subseqüente ao fim da escravidão é visto como um momento privilegiado para se perceber mudanças de referenciais culturais, que até então norteavam relações econômicas, convivência social e de poder. A abordagem agrega ao mesmo tempo o reconhecimento de agentes históricos e os fenômenos coletivos. Elege como forma de análise a seleção de pequenos fragmentos de histórias de vida para esses diversos grupos sociais e também se ocupa em analisar o processo de formação de identidades, levando em conta o declínio do sistema escravista. O último terço do livro é dedicado ao pós-emancipação. Propõe-se a pensá-lo de forma cultural, como sugere o Rebeca Scott. ${ }^{101}$

Com isso em mente me debrucei sobre as fontes e pude verificar, conforme já escrevi e com surpresa que, em Campinas, as coisas não procediam da mesma maneira. Retornemos ao caso de Benedicta: "Benedicta da Silva, preta, de dezenove anos de idade, conforme sua declaração, brasileira, mulher bem constituída" [Grifo meu]. Essas informações estão disponíveis no auto de qualificação da ofendida. Como podemos notar aparece a "cor" dela. É tida por "preta".

É difícil, em processos de Campinas, encontrar um em que não haja indicação da cor dos envolvidos. A partir do final da década de 1890 sobretudo. ${ }^{102}$ É bem verdade que a "cor" aparece, especialmente, quando o processo é ainda inquérito. Quando chega às mãos do juiz e transforma-se de fato em processo só se pode precisá-la pela fala das testemunhas. É válido ressaltar que, mesmo assim, curiosamente, em escala bem reduzida são as falas em que a "cor" do sujeito em questão é mencionada. Isso

\footnotetext{
${ }^{101}$ Vide SCOTT, Rebeca.Obra citada.

102 Ainda não tenho os dados quantificados, mas é certo que, a partir dessa data, encontrei um número bem maior de processos que contivessem a informação da cor da pessoa.
} 
provavelmente tem a ver com a padronização das falas por parte do escrivão, porém é uma questão que demandaria mais vagar do que as pretensões desse artigo.

Ainda sobre o caso de Benedicta da Silva, não só o réu e a ofendida têm suas cores citadas, mas também as testemunhas. Creio que a melhor forma para esboçar uma resposta, para entender o sentido social de cor nesse contexto, é notar como ela, a cor, aparece.

Quando a descrição da "cor", aparece, o primeiro lugar do processo em que podemos vê-la, a descrição da "cor" é na identificação daquele que vai depor: "Lino Primo, branco, com vinte anos de idade, solteiro, brasileiro, filho de Justino de Pala Primo, já falecido, empregado, morador em São Paulo, á rua Vinte e um de Abril número noventa e seis, sabendo ler e escrever". ${ }^{103}$ São informações que permitem ao leitor do processo localizar socialmente a pessoa em questão. Oferecem elementos para que possa conferir maior ou menor peso ao depoimento. E sendo a "cor" a segunda informação a aparecer, suponho que seja elemento deveras importante. Aparece antes mesmo da idade da pessoa, ou do nome de seus pais. Entendo o direito como um campo que agrega tensões diversas. Indivíduos políticos diferentes articulam-no da maneira que mais lhes convém. Ou seja, a "cor" era elemento importante mas não determinante. Ou ainda, cor era mais do que a característica física, carregava mais elementos que tem a ver com a posição social do que se poderia imaginar.

\section{IV (DA EDUCAÇÃO...)}

Lendo jornais negros da décadas de 1920 uma reclamação constante que percebemos é que a educação é tida como a única coisa com poder transformador suficiente para que os negros conquistassem ascensão social. Através da instrução o negro seria perfectível,

${ }^{103}$ CMU, TJC, Estupro, 1913. Victório Gianizelli, doc. 623, of.99. 
logo venceria o preconceito de cor. ${ }^{104}$ Com isso em mente é que me aventurei a ler os processos criminais. Um aspecto me chamou bastante atenção: ainda sobre o caso de Benedicta, os termos que definem o lugar social dos envolvidos. O réu, José Amancio Quirino, fora definido pela policia como preto. Tinha vinte e dois anos de idade, solteiro, nacional, filho de José Amancio, já falecido, empregado, morador no largo Botafogo número vinte, sabendo ler e escrever. Essas informações aparecem no termo de declaração do réu. Um ponto importante a se comentar é que a definição da cor dos envolvidos é definida pelo aparelho policial. ${ }^{105}$ Não sei precisar se fora pelo delegado ou o escrivão propriamente dito nem ao menos se recebiam instruções de padronização. Creio que sim, recebiam certas instruções. De forma geral, no panteão das definições das cores, aparecem os termos "branco", "preto", "mulato" e mais dificilmente "pardo". Interessante notar que em alguns processos, poucos é bem verdade, a pessoa em questão é definida num primeiro momento como "preto", pelos médicos que fizeram o exame de defloramento, e mais adiante como "mulata" no auto de declaração. Outro lugar em que a cor aparece é na fala dos envolvidos. A "mulatinha", "pretinho" etc eram termos recorrentes. Mas é, mais uma vez, difícil afirmar se era definição do escrivão ou se a testemunha havia dito isso. Sobre essa questão há um processo em que o delegado Bandeira de Mello disserta sobre a dificuldade de normatizar a fala das pessoas. Nesse caso em especifico estava se referindo a uma menina que havia sido estuprada e em suas palavras, era "completamente idiota", o que no contexto dá a entender que ela tinha algum tipo de doença mental. E continua afirmando que num caso em que a suposta ofendida é sã já encontrava dificuldades para registrar o discurso de forma condizente com as normas pré-estabelecidas, nesse em específico se tornava a tarefa mais ardilosa.

\footnotetext{
${ }^{104}$ Vide por exemplo o já citado "O Getulino- Orgam para a defesa dos interesses dos homens pretos", 1923-1926.

${ }^{105}$ Curiosamente as informações referentes a cor aparecem sempre, ou quase sempre, nos inquéritos policiais e nos exames de defloramento. Seja na descrição que precede a fala dos envolvidos ou na fala destes. Quando o processo chega a justiça a cor de fato é silenciada.
} 
No caso em questão, tanto réu quanto testemunha são descritos, como pessoas que sabem ler e escrever. Para um período de alguns anos antes, lembremos que o processo é de 1911, raramente encontramos pessoas descritas nos processos como "preta", "parda" ou qualquer outro tipo de identificação, que nos permita inferir que há algum traço de descendência africana na pessoa em questão e que era minimamente letrada. É certo que não há como saber se essas pessoas sabiam ler ou escrever de fato, ou se eram analfabetos funcionais que somente sabiam assinar seus respectivos nomes. Se, como penso, não disseram a verdade, força é reconhecer que não podiam dizê-la se quisessem passar as autoridades uma imagem que os afastasse da estigmatização que sofria gente inculta. Avaliando o desenho das letras, podemos perceber quando a pessoa tem intimidade com a escrita ou não. Letra "tremida", irregularidade no desenho das letras e diferença de pressão em alguns pontos no papel indicam falta de familiaridade. Independentemente disso, o interessante é notar que mesmo que a pessoa não saiba de fato escrever revela o intento de dar ares de civilidade a si, um status mais elevado ao seu depoimento e concomitantemente afastar-se da imagem do cativeiro. E, caso não soubesse ler, também se arriscava a assinar algo sem saber o que estava escrito, haja visto que os processos levam a crer que não eram lidos em voz alta ao depoente letrado.

Não é nova a idéia de se fazer passar por algo que não é de fato. Devido à precariedade da liberdade, o liberto ou escravo que quisesse se passar por tal, tinha de acionar certos mecanismos para ser reconhecido pela sociedade. Mecanismos que vão além das cartas de alforria. ${ }^{106}$ Havia também quem ousasse adotar certas práticas sociais que facilitassemo reconhecimento social. ${ }^{107}$

\footnotetext{
${ }^{106}$ Sobre Alforrias em Campinas vide FERRAZ, L. M. Testamentos, Alforrias e Liberdade: Campinas, século XIX. Monografia (Bacharel em História), IFCH, UNICAMP, 2006.

${ }^{107}$ Augusto Militão tem a respeito uma foto clássica. Há em sua coleção várias fotos de libertos. Uma em especifico chama a atenção. Ele está a imitar um branco, para que seja reconhecido como liberto. Porém não o faz como um branco o faria. Notemos que, primeiramente, suas roupas são um tanto quanto maiores do que deveriam ser. Sobretudo o paletó, cuja manga cobria em demasia uma das mãos. O terno
} 
Pensemos num caso especificamente, o de outra Benedicta. Benedicta Maria da Conceição. Esta é descrita como parda, ${ }^{108}$ nacional, com quinze anos, solteira, filha de Amélia Ferraz de Campos, serviços domésticos, moradora à rua José de Alencar número oitenta e um, não sabendo ler nem escrever. Vejamos a declaração de Benedicta:

Declarou que á 5 anos se empregou na casa de dona Felisberta Menezes Pinto, á rua Alvares Machado número vinte e dois. Era nessa ocasião a declarante bem criança mas conta que já era perseguida pelo filho de sua patroa, de nome Eduardo. A declarante "pernoitava na sala de jantar, perto do quarto do mesmo, e de noite ele vinha até junto da declarante fazer propostas desonestas, sendo porém sempre repelido, motivo porque Eduardo abandonou seu desígnios criminosos; que naturalmente, porém, começou a sofrer novas perseguições, e afinal, depois de muitas promessas de dinheiro a presente, no mês de maio ou Junho do ano passado, entregou-se a Eduardo, sendo desonrada as seis horas da tarde em ocasião em que se achava ausente a patrôa; que depois isso continuou ainda por dois meses a ter relações com Eduardo, até que enfim despediu-se da casa indo empregar-se na casa do sr. José Bravo.

Trabalhar em "casa de família" era, sem sombra de dúvidas, a profissão mais comum entre as mulheres negras. ${ }^{109}$ As que aparecem nos processos ao menos, em sua maioria, são empregadas domésticas ou lavadeiras. Interessante notar nessa passagem que Benedicta passou a morar com sua patroa, ainda criança. Segundo duas das testemunhas trabalhava lá há cinco anos. Quando há três meses de lá saiu, indo refugiar-

amarrotado é sinal de que provavelmente essa roupa não era dele, fora alugado, ou é roupa do próprio estúdio do fotógrafo. Ele está usando uma bengala, símbolo de distinção social, porém, curiosamente, não sabe utilizá-la. Ao invés de apoiar-se nela está apoiado junto ao muro.

Vide KOSSOY, Boris, e CARNEIRO, M. L. T, O olhar europeu: o negro na iconografia brasileira do Século XIX,. São Paulo, Edusp, 1994.

${ }^{108}$ No exame de corpo de delito também é descrita como parda.

${ }^{109}$ Em algum momento entre 1886 e 1887 no jornal Gazeta de Campinas acompanhamos uma mudança nos anúncios para vagas de empregadas. Ao invés do tradicional "precisa-se de cozinheira", sem qualquer identificação de cor passa-se a acompanhar o termo "prefere-se brancas". Isso não é suficiente para dizer que as negras estavam em postos menores e eram mal remuneradas por isso, mas é fato que ao menos parte da população mais abastada tinha preferência por ser servida por gente branca. O que por si pode nos levar a conclusão de que as trabalhadoras negras aqui tratadas estão, em grande maioria, não necessariamente nas casas das elites. 
se na casa de Cypryana Aurora Gomes, quando saiu da casa da mãe do dentista Pio Pinto. ${ }^{110}$ Aparentemente era quem tinha relacionamento mais intimo com Benedicta, já que morou em sua casa até os onze anos e não na de sua mãe, que a época do ocorrido era "amasiada com um preto" como afirma Francellina da Costa mais adiante no processo. O réu Eduardo Pinto Silva, branco, com trinta e sete anos, solteiro, brasileiro, filho de Eduardo Pinto de Almeida, já falecido, empregado do comércio, morador á rua Alvares Machado número vinte e dois, sabendo ler e escrever, por sua vez, negou ter tido relações sexuais com ela e afirmou que havia deixado sua casa há seis meses. Segundo ele queriam "lhe extorquir dinheiro".

Já diante do juiz, algumas semanas depois, a primeira pessoa a depor foi Francellina da Costa, solteira, com trinta e sete anos, natural da cidade de Itú, e residente nesta cidade de Campinas, lavadeira. Era também madrinha de Benedicta. Disse -lhe que "estava alugada em casa de dona Felisberta", mãe do denunciado, quando decorrido o ato que a fez engravidar. O que significaria estar "alugada"? Mais adiante Cypryana fala sobre isso novamente:

(...) fora agregada e alugada seus serviços em casa de Dona Felisberta, aonde se conservaria até uns quatro meses atrás, mais ou menos, quando inesperadamente, fugira dali acolhendo-se a casa da depoente, e que a ofendida queixava-se nessa ocasião de estar sofrendo de uma suspensão de regras; que tendo melhorado um pouco o seu estado de saúde, fora para a casa de José Bravo a pedido destes mas que decorrido três meses, agravando-se os incômodos da ofendida, aquele cidadão fizera com que regressasse para a casa da depoente (...). [Grifo meu]

Há alguns pontos a comentar. Primeiramente a rede de relacionamentos de Benedicta foi fundamental para que arranjasse emprego. Curiosamente as pessoas que vem depor a seu favor são parentes próximos e amigos. Seu padrinho, José Ribeiro de

\footnotetext{
${ }^{110}$ Aparentemente trata-se de um dentista famoso na cidade.
} 
Saraiva, disse que sabia do ocorrido apenas de ouvir dizer, e que desde o nascimento de sua afilhada não se envolvia com sua vida, desconhecendo que estava "alugada" inclusive. A expressão "alugada seus serviços" clarifica que, de fato, quem esta alugada não é Benedicta, mas sim seus os seus serviços. Embora, é bem verdade, a autoridade sobre a menor tenha sido exercida diretamente pela patroa. Segundo a mãe de Benedicta, Amélia Ferraz Campos, a patroa da mesma exercia vigilância sobre a menor, em cuja companhia saia a passeio. Amélia ia visitar sua filha às vezes. Assim como a filha ia visitar outras tantas, a madrinha, a qual, por sua vez, mandava que a mesma visitasse Amélia, fazendo a ser acompanhada por sua criada. Sequer tinha o hábito de ir às compras. Embora tivesse gênio forte Amélia não gostava que sua filha "freqüentasse o portão de sua casa conversando com homens", o que era repreendido por sua patroa. Segundo ela, era de fato amigada com "um preto de nome Belchior", mas que tomava o cuidado de não deixá-los sozinhos. Quanto não estava em casa Benedicta não entrava. Na casa de Dona Felisberta trabalhava como cozinheira. Na casa de Dona Felisberta não havia criados e com eles morava apenas um sobrinho ainda criança.

$\mathrm{O}$ advogado de defesa apresenta alguns itens interessantes. Primeiramente define a relação entre Benedicta e sua patroa como de "dependência". E o que significava isso? Segundo Cypriana: "num dia que não se recorda,o dentista Pio Pinto, irmão do acusado, apareceu em sua casa antes do almoço em companhia da mãe da menor. Ela se retirou quando entrara na sala e ouviu o dentista fazer a oferta de cinqüenta mil réis. Não sabe, por fim, qual o fim da referida proposta”. Isso ela diz na delegacia, já diante do juiz afirma a respeito do dinheiro que o irmão do réu teria oferecido a mãe de Benedicta que o "intuito de dar-lhe uma gratificação pelo fato de não ter a menor ofendida recebido salário algum durante o tempo que esteve em casa do denunciado". Ou seja, Benedicta 
esteve cinco anos trabalhando como cozinheira em troca de comida e um lugar para morar.

A pergunta que fica é, porque motivo a família de Benedicta queria empregá-la de todas as formas, ainda criança numa "casa de família" mesmo sem receber salário? Seria para que a mesma tivesse possibilidades de ter maior sorte na vida? Para o advogado de defesa essa possibilidade era nula. Segundo ele: “(...) o temor de revelar essa falta o pudor da donzela, ferida com a perda de sua honra. Este sentimento é próprio de pessoa educada em meio elevado, onde se cultivam os princípios de uma moral sã. Benedicta, pela sua origem e condição, não é um exemplar dessa natureza".

A argumentação dessa passagem é reveladora. Elucida a forma como o advogado entendia a questão da "cultura de classes", ou seja, reconhece a possibilidade de existirem valores diferentes para pessoas com ascendência social diversa, de uma forma negativa alias: os pobres não tem moral. Interessante para pensar na questão levantada por Martha Abreu de que esses valores diferentes existiam e que os advogados "esqueciam-se" disso. O meio social, portanto é tido por relevante. E mesmo que ele não creia nisso de fato, o importante é que sua utilização revela que esse argumento estava dentro das possibilidades cogitadas.

\section{VI (SOBRE A HONRA)}

A polícia trabalhava, basicamente, com dois tipos de imagens. A da vagabunda e a da mulher honesta, como dois lados de uma mesma moeda. Martha Abreu e Sueann Caulfield já demonstraram que para a mulher pobre era deveras difícil se enquadrar na categoria "honesta". Seu padrão de comportamento fugia daquele estabelecido como o normativo pelos discursos médico e jurídico. 
Como vimos no capítulo anterior, a imagem da mulher considerada vagabunda, diferente do homem, para a qual o ócio levava a um patamar pior. Para além do não trabalho, entregava-se à prostituição. Ao invés de pensar honra na perspectiva daquelas que se diziam honestas entendo ser mais interessante pensar honra na perspectiva daquelas que, definitivamente, não se esforçavam para se enquadrar nessa classificação. Vejamos o caso de algumas mulheres que sofreram com a perseguição policial.

Eis que enfim chegamos ao caso que prometi no final do último capítulo. Eva Maria da Conceição ${ }^{111}$ tinha a pele escura, ${ }^{112}$ era casada sem oficio certo. Natural de Campinas,de filiação segmentada. ${ }^{113}$ Tinha então 23 anos de idade.

Ela é incursa no artigo 399 do código penal. O primeiro processo que se formou envolvendo a ré leva a acusação de ser vadia. Havia sido presa muitas vezes pelo mesmo motivo. Característica essa muito comum na maioria dos casos. É provável que passassem a noite na cadeia e eram soltas. Nesse caso, segundo o carcereiro, foram 12 prisões. Ora por embriaguez, ora por vadiagem e também por desordem.

É interessante pensarmos em quem são as testemunhas. As duas primeiras residiam à Rua General Carneiro, no nº 26. Eram eles Carlos Guimarães e José Antonio Rabello. Provavelmente a coincidência de endereço é sinal de que moravam em algum tipo de habitação coletiva, o que aliás era um meio de habitação popular comum em Campinas nesse período. ${ }^{114}$

\footnotetext{
${ }^{111}$ Segundo Silvana Santiago, a adoção do nome conceição indica uma estratégia da ré para se passar por anônima, já que era um nome bastante comum, ao menos para o caso carioca. No caso de Campinas não sei se tal consideração é valida pois o único processo envolvendo tal sobrenome é esse e não tive acesso ao livro de registro de entradas e saídas da cadeia. Vide SANTIAGO, Silvana, Tal Conceição, Conceição de Tal. Classe, gênero e raça no cotidiano de mulheres pobres no Rio de Janeiro das primeiras décadas republicana. Dissertação (Mestrado em História), IFCH, UNICAMP, Campinas, 2007.

${ }^{112}$ A indicação da cor da pele da ré aparece em.no depoimento do delgado no segundo processo. Diferente do que acontece em outras regiões do pais, em Campinas a indicação da cor é quase sempre evidente para o período estudado. Há casos em que a cor vem indicada na folha de rosto do processo, outros em que aparece na boca do delegado ou de uma testemunha, e às vezes de forma estranha, indicada entre parênteses após o nome da pessoa em questão.

${ }^{113}$ No primeiro processo analisado aparece a indicação de pais incógnitos, no segundo a ré declara seus pais.

${ }^{114}$ Segundo Edmir de Carvalho os cortiços eram o maior tipo de habitação popular existente na cidade no
} 
Carlos Guimarães era carioca, com 25 anos e empregado no comércio. Era solteiro, e não sabia ler nem escrever. Já José Antonio Rabello tinha 26 anos, natural do Estado de São Paulo, solteiro, empregado na Companhia Mogyana.

Ambos concordam sobre a "vagabundagem" de Eva. Carlos Guimarães enfatiza que "Eva lingüiça" embriagava-se habitualmente e nesse estado promovia a desordem. A ênfase no apelido de Eva percorre todo processo, inclusive o delegado quando se refere a ela em seu relatório final utiliza-o claramente de forma pejorativa. Já José Antonio Rabello nos informa que ela ficava em frente ao "Rink", promovendo a desordem.

A terceira testemunha é Leoncio Ferraz de A. Campos, também natural deste estado, com 26 anos, solteiro, oficial de justiça. Sabendo ler e escrever. Em seu depoimento reitera a questão da vagabundagem "conhecida" de Eva. A habituidade de seu estado de embriaguez mais uma vez é notada. A informação que diferencia seu depoimento dos demais é que ela diz que Eva é sempre vista nos botequins que ficam na Rua da Conceição, em frente ao "Rink".

Como podemos perceber para as três testemunhas, Eva era culpada porque bebia e assim sendo provocava desordem. Há várias questões sendo acionadas nesse argumento. O relatório final do delegado as deixará mais explicitas.

Segundo Bandeira de Mello, Eva que tinha apenas 23 anos, e não sofria de qualquer moléstia, preferia ficar "bebendo pelas tabernas" ao invés de trabalhar, na mais completa ociosidade. Em suas próprias palavras:

Prostituta de baixa ralé, entrega-se por alguns reis ou por um copo de aguardente, ao primeiro que solicita seus favores conforme informaram-me os agentes de policia desta delegacia.

inicio do XX. Vide CARVALHO, Edmir de. Habitação Popular em Campinas. Dissertação (Mestrado em História), IFCH, UNICAMP, Campinas, 1991. 
Sem domicilio, ela dorme na casa daqueles que desejam gozá-la, ora nos largos e ruas desta cidade, onde as dez horas, por diversas vezes tem sido presa por praticar cenas da mais desregrada orgia. Com indivíduos de sua laia. Perdeu completamente o brio e não tem ela o menor receio da prisão, na qual faz quase sua residência. $^{115}$

Bandeira de Mello aciona a questão da honra. Há uma série de estereótipos sobre o papel da mulher que estão presentes em sua fala. Esse não é o único caso em que vemos associadas a vadiagem da mulheres à prostituição. ${ }^{116}$ Temos também, por exemplo, o caso de Francisca Maria da Silva, vulgarmente chamada de "Chiquita vagabunda", qualificada por uma testemunha como "prostituta de baixa esfera". ${ }^{117} \mathrm{O}$ problema da vadiagem, em ambos casos, vai para a questão do beber que as leva a ter um comportamento moralmente inaceitável, conduzindo-as inevitavelmente a se prostituir como ápice de suas desonras. No caso dos homens, esse comportamento se dá de outras formas, levando ao furto e ao roubo. Mas, voltemo-nos ao caso de Eva. Pretendo voltar ao caso citado acima mais adiante.

A questão que se põe agora é: Como Eva consegue negociar com isso? Haja vista que se encontra completamente fora do padrão aceitável, e ela, mais do que ninguém vivenciava isso na pele cotidianamente. Era negra, embriagava-se e talvez até se prostituísse. No primeiro processo confessa, ou melhor, não contesta os depoimentos das testemunhas - o que para o delgado Bandeira de Mello é a mesma coisa - e o juiz a fez assinar o termo de bem viver. ${ }^{118}$

\footnotetext{
115 Centro de memória Unicamp (CMU), Tribunal De Justiça de Campinas (TJC). Processo de contravenção de vadiagem. Eva Maria da conceição [ré], caixa 20, nº291.

${ }^{116}$ Vide também os trabalhos de GARZONI, L. de C. Vagabundas e conhecidas: novos olhares sobre a polícia republicana (Rio de Janeiro, início do século XX), Dissertação (Mestrado em História), IFCH, UNICAMP, Campinas, 2007; e SANTIAGO, Silvana. Op. Cit.

${ }^{117}$ CMU.TJC. Processo de contravenção de vadiagem. Francisca Maria da Silva [ré], caixa 272, nº6365.

${ }^{118}$ Termo de bem viver era um documento que o réu era obrigado a assinar quando saísse da cadeia. Nele se comprometia em procurar ocupação honesta em um prazo máximo de 15 dias.
} 
Em junho novo processo foi formado. Segundo o carcereiro, dessa vez foi presa em mais quatro oportunidades, três por embriaguez e uma por desordem. A comparação com o primeiro processo me leva a crer há hipótese de que Eva tentou criar algumas estratégias para confundir a policia, ou para mudar a visão que tinham de si, ao menos. Talvez nem estivesse pensando no delegado, mas no juiz. De pais incógnitos, passou a declarar-se filha de Isaías e Maria, ${ }^{119}$ e por fim residia à Rua Benjamim Constant, $\mathrm{n}^{\circ} 4$ há 15 dias, conforme consta em seu depoimento. De vagabunda que vivia "bebendo pelas tabernas", passou a ser sujeito. Alias, é estranho que nem o policial, muito menos o juiz, falam sobre seu suposto marido nas duas oportunidades. Era a sua tentativa de rebater todas as qualidades que faziam dela uma vagabunda aos olhos da policia, da sociedade e da lei. A única coisa que lhe faltava era um emprego, e Eva logo tratou de se explicar na sua defesa. Disse que resolveu lavar roupa a "Beatriz de tal", moradora de um Bordel na Rua Campo Salles. Ficou lá 20 dias e saiu porque lhe disseram que ela nunca pagava a ninguém.

Vejamos mais uma vez as testemunhas. A primeira é Euclides Ferreira de Andrade, branco, 29 anos, solteiro, brasileiro, filho de José Ferreira de Andrade; farmacêutico, morador à Rua Moraes Salles, $\mathrm{n}^{\circ} 165$, sabendo ler e escrever. ${ }^{120}$ Afirmou que desde quando era autoridade conhece Eva como ébria e desordeira. Também se mostrou ciente de que ela havia sido presa esse ano e condenada e que em nada mudou desde o ocorrido.

A segunda testemunha é Joaquim Rodrigues de Faria, branco, com 30 anos, casado, brasileiro, filho de José Faria, já falecido, negociante, morado à rua General Carneiro $\mathrm{n}^{\circ} 70$, sabendo ler e escrever. Define a ré como “(...) a mais incorrigível das

\footnotetext{
${ }^{119}$ No primeiro processo analisado aparece a indicação de pais incógnitos, no segundo a ré declara seus pais.

${ }^{120}$ A indicação da filiação das testemunhas tem sido comum nos processo até aqui analisados.
} 
vagabundas que envergonham esta cidade". Também se mostrou ciente de sua condenação através dos jornais.

Enfim, temos a terceira testemunha. Antonio Joaquim Ribeiro Júnior, branco, com 33 anos, filho de Antonio Joaquim Ribeiro, casado, brasileiro, negociante, morador a rua Regente Feijó, $n^{\circ} 24$, sabendo ler e escrever. Disse que Campinas inteira conhece a acusada como vagabunda, desordeira e ébria. E que não lhe consta que tivesse sido empregada.

Como pudemos perceber novamente o estigma de vagabunda acompanha Eva. É interessante notar que aqui a cor aparece, diferentemente do primeiro processo. Passemos, pois, ao interrogatório da ré.

Quando perguntada a que deve o presente processo disse entender que se deve “(...) a perseguição da policia, pois não é ela a única vagabunda desta cidade, existindo outras mais desordeiras que ela acusada e que, entretanto, não são processadas".

Acredito que a esta altura do interrogatório tenha aceitado o estereotipo de vagabunda, uma vez que todas as testemunhas foram enfáticas na questão da vadiagem e a própria inclusive não contestou os depoimentos. A situação se complicava mais, restava-lhe provar que havia buscado emenda para seu comportamento. Mais à frente disse que procurava emprego quando fora presa novamente. Por fim temos que Eva acabou sendo condenada pelo juiz a um mês e cinco dias de reclusão.

Passemos a um caso agora em que a personagem obteve êxito. O processo deu inicio no dia 20 de fevereiro 1907. A personagem dessa vez é a já citada Francisca Maria da Silva. Declarou ter 16 anos e ter acabado de completar em 25 de março ultimo. Natural de São Jose do Paraíso, morar à Rua Major Solano. Era filha de Raphael Manuel dos Santos e Joanna Maria dos Santos. Vejamos, pois, a declaração das testemunhas. 
Gastão de Castro, branco, filho de Mathias de Castro e Maria [nome ilegível], ambos vivos, empregado no comercio, caixeiro na "casa Americana", residente à rua Doutor Quirino no 22, sabendo ler e escrever disse que há muito conhece a ré de "vista", como prostituta de baixa esfera. Afirma vê-la em frente ao "Rink", seja noite ou dia, em botequins da Rua Conceição, entre a Barão de Jaguará e a Francisco Glicério. E continua sal denuncia:

(...) que tais casas de bebidas nessas ocasiões acumulamse de mulatos, e pretos, de ambos os sexos, tidos e havidos como vagabundos, sendo freqüente embriagar-se fazerem desordens; que, entretanto, nunca reparou se Francisca Maria da Silva (...) estivesse bêbada; [Grifos meus.]

Gastão nos dá acesso a conhecer um espaço de sociabilidade importante para os negros nesse período, os botequins do centro da cidade. Campinas se urbanizava, e os negros lotavam os cortiços no centro da cidade, á reboque apareciam os botequins. Não encontrei uma descrição exata desse tipo de lugar, mas encontrei um processo movido contra Paulo Cattani, por incentivar à vadiagem, em que podemos ver como funcionava uma casa de tavolagem. ${ }^{121}$ Mas antes terminemos de acompanhar a história de Francisca.

A segunda testemunha é José Lopes de Castro Dias, branco, casado, natural do Rio de Janeiro, com vinte e três anos de idade, filho de José Lopes Mendes e Francisca Figueira Dias, ambos falecidos, empregado no comércio [nome ilegível]; sabendo ler e escrever.

Castro Dias revela que seu apelido seria “Chiquita Vagabunda”. Afirma que

(...) essa rapariga anda sempre com outros mulatos e pretos, apontada geralmente como meretrizes de baixa estirpe, razão pela qual a reputa do mesmo comercio

${ }^{121}$ CMU.TJC. Processo de contravenção de vadiagem. Paulo Cattani [réu] Caixa 21, nº324. 
ilícito; que ela, não só estaciona pelas esquinas, em palestra com sujeitos de má nota, mas ainda freqüenta os botequins da rua Conceição, próximos ao Rink, onde se reúnem alcoolistas e malandros; que, em noites de divertimento publico, quando as aludidas casas permanecem abertas até alta hora, repletos de vicio, ali se acha Francisca Maria da Silva ou Chiquita Vagabunda; que finalmente não pode afirmar que se além de ser vadia, a acusada é ainda ébria.

Como é possível ver na fala da testemunha, mais uma vez vemos associação entre negros e vicio. Para ela, só o fato de que Francisca ande acompanhada de "pretos" e "mulatos" já é motivo suficiente para considerá-la vagabunda. As insinuações quanto a sua honra, mais uma vez, se fazem presentes.

A terceira e ultima testemunha, é novamente Leoncio Ferraz, o mesmo que testemunhou contra Eva. Repete novamente o discurso dos dois últimos. Parece que para eles, os ambientes que freqüenta. Leôncio também não sabe informar se a ré é ébria.

Bem, vejamos o que a ré tem a declarar sobre sua situação. De inicio já admite ter "caido na vida". Afirmou residir a Rua Major Solano, desde essa época. Que as vezes muda de casa, mas sempre volta a referida rua. Declarou que é de São Jose do Paraíso, Minas Gerais; que vive da ajuda de uns e outros, e foi presa ao sair do botequim de Francisco Villela a Rua Dr. Quirino. Quando interrogada sobre o que poderia alegar que provasse ou justificasse o que fez contou a seguinte história:

Disse que, órfã de pai quando perdeu a mãe, ficou sob a guarda da família do senhor Francisco de Oliveira, que no principio de 1903 fugiu para casa do senhor Ferraz, fiscal do serviço de limpeza publica, e daí para companhia de um namorado, o pretinho de nome Elydio, atualmente de [ilegível] Tillbury, o qual a deflorou em março daquele ano, tendo ela apenas dez anos de idade; que um mês após, abandonada pelo sedutor começou entregar seu corpo a diversos embora não fizesse disso um meio exclusivo, pois trabalhava ainda; que de seis mês a esta parte, já 
prostituída e não obtendo mais emprego honesto, entrou francamente no comercio ilícito, a fim de ganhar a subsistência, recebendo ainda cinco mil réis por aposta; que mora com outra meretriz de nome Lucilia Salles, à rua major Solano, ajudando-a no pagamento de aluguéis da casa com dez mil réis mensais, quando tem dita quantia; que as vezes se embriaga, é certo, mas que não sai a rua em tal estado, para dar escândalo; que só numa ocasião aconteceu ser recolhida de bêbada pela policia; que é também verdade que em noites de espetáculo freqüenta os botequins da Rua Conceição, onde há gente ruim, isso porque não a admitiram nos de consideração; que finalmente, não tem o costume de provocar desordem, por má índole ou sob influencia do álcool, havendo apenas repelido ataques dos que a insultam.

Peço desculpas ao leitor pela longa citação, mas é que o texto traz muitos elementos para serem explorados. Primeiramente ela não foi condenada, o processo foi anulado por problemas de execução. O objetivo era deixar o ambiente inóspito para trabalhadores rurais que tencionassem viver no centro. ${ }^{122}$ Dos processos que pude ler, apenas um não se passa em zona urbana. Os processos parecem indicar que o aumento no efetivo policial se destinava justamente a conter essa população que ocupava o centro da cidade. Os valores que ela indica a respeito do que ganhava revela que não tinha dinheiro para freqüentar o "Rink". A segregação como a própria indica existia.

O várias vezes citado como "Rink" era o "Theatro-Rink" uma casa de shows que existia em Campinas. Situava-se à Rua General Carneiro. Existem a respeito deste lugar varias propagandas nos jornais que datam de pelo menos 1886. Em geral envolvia espetáculos com ilusionistas e shows em geral. Num espetáculo de 1886, o camarote custava 10 mil réis. Não estou certo se alguém pobre teria condição de ir a um espetáculo desses, era o preço de metade de um aluguel como indica Francisca, considerando que sua colega de quarto dividia o aluguel pela metade.

${ }^{122}$ FRAGA FILHO, Walter. Mendigos, moleques... Obra citada..pp. 174 e 178 
É interessante como mesmo se admitindo prostituta, Francisca constrói o discurso induzindo o leitor a pensar que as circunstâncias da vida a fizeram assim, afirmando não ter escolhido de vontade própria "cair na vida" e freqüentar lugares de má reputação. Não há como saber se as coisas que ela relata de fato aconteceram, e nem é o objetivo deste trabalho, mas a questão é que a forma como essa estrutura a sua narrativa aponta o dedo para o vicio ao invés do viciado.

\section{VII (ÚLTIMA ANÁLISE)}

Creio que cabe aqui uma última análise antes do fechamento do capítulo. Refiro-me ao caso entre Benedita (sim leitor, mais uma Benedita) e seu noivo: Franklin de Camargo. ${ }^{123}$ Corria o ano de 1914. O interessante desse caso é que se trata de um casal que reconhecidamente para si e para os demais envolvidos era de fato um casal. Coincidência ou não eles possuem a mesma cor. Ao menos é o que é descrito no processo. Benedita e Franklin são descritos por pardos. Assumindo que os personagens que estão a analisar a cor dos referidos são os mesmos dos demais casos é possível que pardo possa significar negro. Isso posto vamos ao caso.

A ofendida é Benedita de Moraes, parda, com dezoito anos de idade, solteira, natural desta cidade. Filha de José Teixeira de Moraes, serviços domésticos, moradora em Valinhos, não sabendo ler nem escrever. O réu: Franklin de Camargo, pardo, com vinte e dois anos de idade, solteiro, natural desta cidade, filho de Manoel Francisco de Camargo, ainda vivo, oleiro, morador em Valinhos, sabendo ler e escrever. Ambos declaram que são namorados.

Franklin diz que há dois anos namora Benedita, chegou a pedi-la em casamento, não se realizando até hoje por falta de recursos. Benedita que a cerca de três anos foi

${ }^{123}$ TJC, CMU. Processo n ${ }^{\circ} .10399$ 
pedida em casamento pelo seu namorado e jamais quis o mesmo fixar a data do evento declarando, sempre que era interpelado, que estava se preparando.

Há cerca de cinco meses Franklin teria sido avisado por vários amigos que sua noiva não era honesta, pois foi desonrada a tempos por um tal Manoel Rocha. Por estimá-la, diz ele, não quis dar ouvido a tais boatos, porém, há quatro meses, verificou que numa noite, cerca de dez horas, estando com sua noiva na casa desta no quintal, convidou-a a ter com ele relações sexuais. A declarante afirma ainda que, por diversas vezes, o mesmo convidou a para terem relações sexuais, argumentando que eram noivos e por isso não fazia mal. Esta se recusou, porém o declarante disse a ela que queria tirar a prova por ser ela muito mal falada em Valinhos. E assim conseguiu ter com ela relações e confirmar que de fato já era desonrada,o que ela por sinal negou. Em contrapartida Benedita afirma que há cerca de seis meses, em data para declarante não se recorda, estando a declarante só em casa com seu referido noivo, este agarrou a declarante e deflorou-a, prometendo que casaria sem falta; que a declarante continuou a ter relações sexuais com Franklin até que, há cerca de dois meses, o mesmo deixou de freqüentar a sua casa, dando sempre desculpas quando se encontrava com a declarante; que, finalmente, há quinze dias a declarante contou tudo a sua tia Cesarina Gomes, visto desconfiar que Franklin procurava fugir á promessa de casamento.

Como podemos notar as duas histórias são praticamente a mesma, ela apenas difere na interpretação. Benedita afirma que Franklin fora seu único homem até então e esse diz que a informação não procede.

Duas testemunhas, brancas, confirmam a História de Franklin. Provavelmente são os “amigos" que lhe disseram ser essa moça desonesta. Dizem que ela teria se deitado com um tal Manoel Rocha, posto que o mesmo teria lhes contado. E é com essa informação que o juiz vai dar ganho de causa o réu. Isso evidencia que nessa sociedade se os negros 
ocupam papel de categoria inferior as mulheres negras ainda são menos levadas a sério. Uma vez que a palavra de dois vizinhos, que não são testemunhas oculares foi suficiente para que se julgasse a denúncia improcedente. Fica a lição. 


\section{CONCLUSÃO}

Eis que enfim chegamos ao término dessa dissertação. Restam ainda com dois ou três pontos ainda a comentar. Primeiramente há de se ressaltar a continuidade que existe, em certa medida, entre o período escravista e o pós-emancipação. O que não significa dizer que são situações idênticas. De um lado temos a conquista da liberdade física plena, de todas as pessoas de pele escura. Na teoria essas possuem os mesmos direitos os brancos ou os imigrantes, seus concorrentes nos postos de trabalho. Na pratica, o racismo os leva a traçar alternativas e estratégias de sobrevivência a fím de driblar esse tipo de prática. Por outro lado, a experiência prática mostra-nos que essas pessoas eram tratadas como quase-cidadãs, uma vez que eram tidas como cidadãs de segunda classe, regidas pela policia a partir da prática da suspeição generalizada.

Acredito que muito da experiência adquirida no período escravista era utilizado pelos ex-escravos e seus descendentes, principalmente no que tange as formas de negociação - seja no âmbito da justiça, ou negociando com o patrão.

Diversos sentidos para vadio eram acionados. Numa leitura a contrapelo, do ponto de vista daqueles que criaram a lei de repressão, vadio era aquele que não queria sujeitar-se a uma lógica de trabalho capitalista, que não estava disposto a enfrentar determinadas condições de trabalho, e muito menos abrir mão de algum tipo de lazer. Em outras palavras, vadio era um termo, sobretudo, atrelado aos libertos e seus descendentes.

Verificamos na prática que a repressão agia de forma mais incisiva sobre essa população negra. E, de certa forma, contava com a anuência de parte da população.

Quando mulher, a acusação contra a ré geralmente estava atrelada a questão da moralidade. $\mathrm{O}$ ato de beber, suster-se através da prostituição, era visto de forma muito 
negativa. E vadia, para a policia e para a maioria das testemunhas, era aquela mulher que devido ao ambiente, aos maus costumes, a convivência com outros negros possuía um comportamento desregrado que não atendia os padrões morais vigentes. 


\section{ANEXOS}

\section{Carta apresentada pelo advogado de Guilhemina, Antonio Alvares Lobo.}

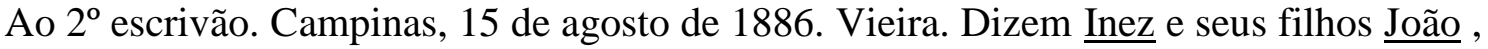
Eva e Henriquetta, que passam por escravos de Domingos Francisco de Moraes, Josephina e Valentina, de Octaviano Pompeu do Amaral, Olympia, de D. Maria Umbelina; e Clementina de D. Maria Angêla de Souza Aranha, viúva, do finado Major Carlos Egydido de Souza Aranha, a $1^{\text {a }}$ e demais Supp..es [?], filhos e netos de Guilhermina, atualmente liberta, que vêm requerer a $\mathrm{Vs}^{\mathrm{a}}$ o Seguinte:

A liberta Guilhermina, mãe e avó, Supp.es, é africana de nação. Veio para o Brasil, importada em navios negreiros, que conduziam da África pretos para o comércio de trafico neste Império. Devendo cessar o vil comércio por virtude até de convenções internacionais, fez-se promulgar a Lei de 7 de Novembro de 1831. Entretanto, apesar da proibição legal, como está na consciência de todos, a lei foi burlada em seus efeitos continuando-se no nefando tráfico de homens livres, que desde aquela época nem mais legalmente podiam ser considerados como propriedade licita. A Africana Guilhermina, avó e mãe dos Supp.es, veio [rasurado] das levas, quando já a mercadoria precisava, para entrar, escolher as desvezas [?], escondendo-se dos cruzeiros ingleses que batiam em [águas] brasileiras, furtando-se a vigilância das autoridades territoriais do Império, fazendo seus desembarques em lugares desertos e ocultos e seguido o destino que o esperava á noite, para que o roubo fosse mas perfeito e mais repulsiva a conculcação de direitos tão sagrados. Guilhermina entrou no Império como escrava, quando o tráfico estava proibido e eram jugados livres o escravos vindo de fora: "Lei de 7 de Novembro de 1831 art. $1^{\circ}$; doc. $\mathrm{N}^{\mathrm{o}} 1$. Tua descendência continuou no cativeiro apesar de ter nascido de pessoa livre, que viveu como escravizada.

Assim, pois, os Supp.es querem propor a competente ação de liberdade em seu favor. Com a devida e respeitosa venia [?], pedem a V.S serra-se mandar citar os senhores dos Supp.es - Domingos Francisco de Moraes, Octaviano Pompeu do Amaral, D. Maria Umbelina Bueno e D. Maria Angela de Souza Aranha para á $1^{\text {a }}$ audiência posteriro á citação virem assistir a propositura da competente ação em que:

$1^{\circ} \mathrm{PP}$.

A preta Guilhermina, Mãe e Avó dos Supp.es é africana de nação.

$2^{\circ} \mathrm{PP}$.

Que foi importada, como escravizada, depois de 7 de novembro de 1831.

Que, assim sendo, os Supp.es, filhos e netos, sua descendencia considerada escravizada, são livres de direitos e de fato, sem embargo da permanência em que se têm estado no cativeiro; 
Que os Supp.es são os mesmo quanto a sua identidade.

Nestes termos, requerem que a presente seja distribuída e autuada com os doc.juntos. Oferecem as certidões de filiação Inez (doc. $\mathrm{n}^{\circ} 2$ ); de Clementina (doc. $\mathrm{N}^{\mathrm{o}} 3$ ); de Josephina (doc. $\left.{ }^{\circ} 4\right)$; de Olympia (doc. $\mathrm{N}^{\circ} 5$ ); de Henriquieta (doc. $n^{\circ} 6$ ), não tendo encontrado os assentos de Valentina, João e Eva, protestando dar prova de sua filiaçãoe tempo legal.

Assim,

P.P. a VS. ${ }^{a}$ que mande citar com [rasurado]devida venia [?] que respeitosamente impretam, aos Supp.os na forma requerida, depositando-se os Supp.es em poder de pessoa eclonea, dando-se [continua].

Campinas, 13 de dezembo de 1886. Arrogo os Supp.es por não saberem ler nem escrever.

O advogado, Antonio Alvares Lobo. 


\section{FOTOS}

Seguem a seguir algumas fotos sobre regiões da cidade as quais fiz menção durante o texto (excetuando a primeira). Aqui estão para que o leitor possa ter uma referência visual da cidade. ${ }^{124}$

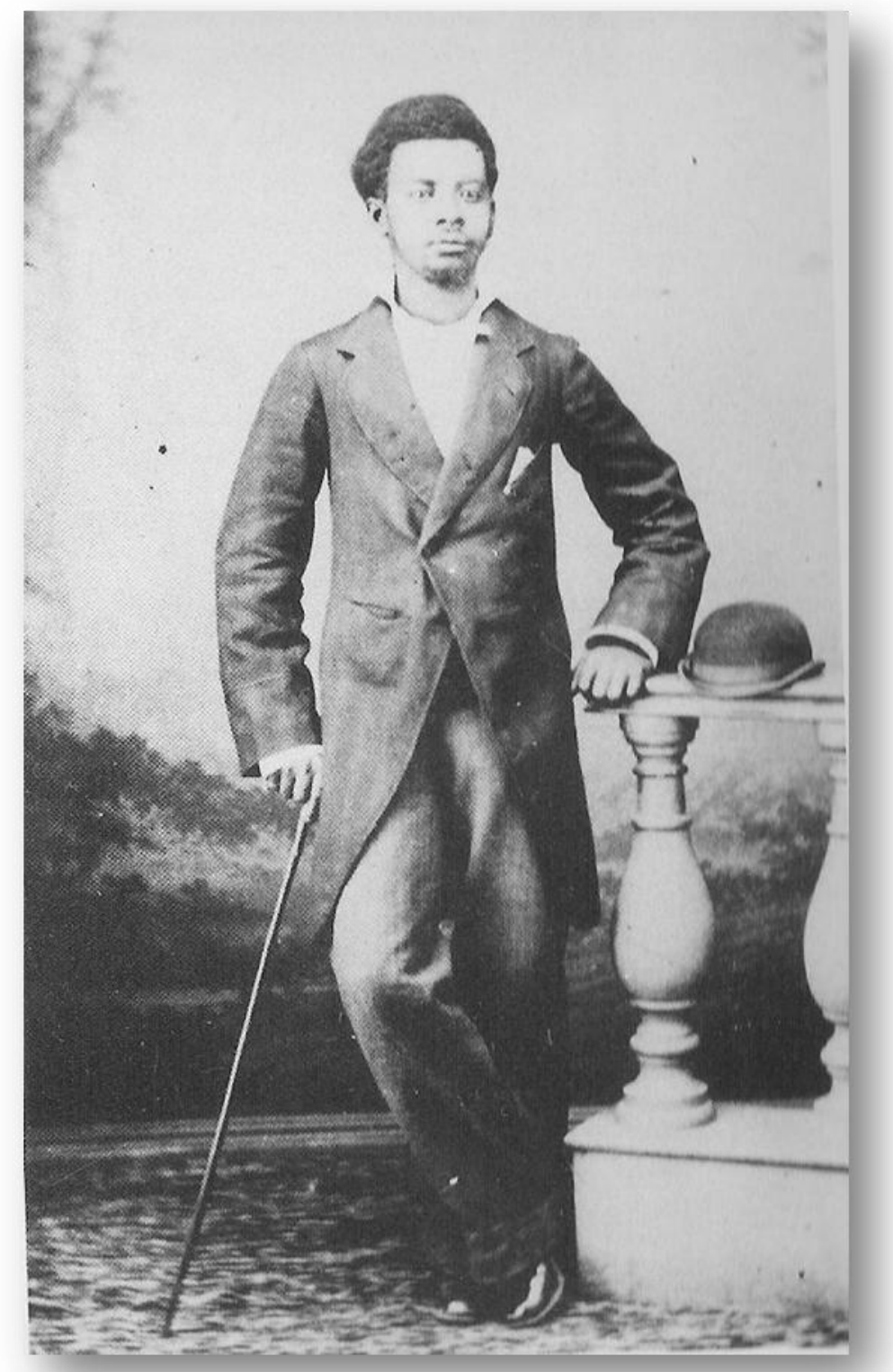

\section{MILITÃO DE AZEVEDO, ESCRAVO} ALFORRIADO? 1883.

124 Excetuando a prim.u... .u. un campinas-sp.blogspot.com/ 


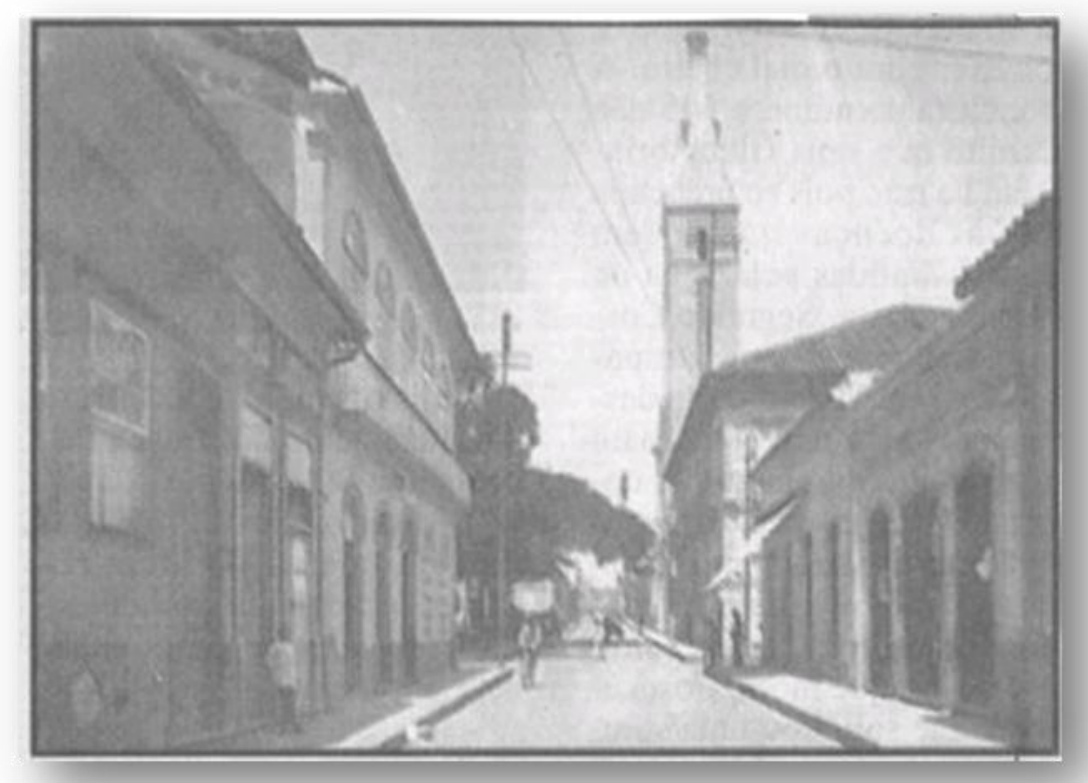

RUA FRANCISCO GLICÉRIO EM 1920.

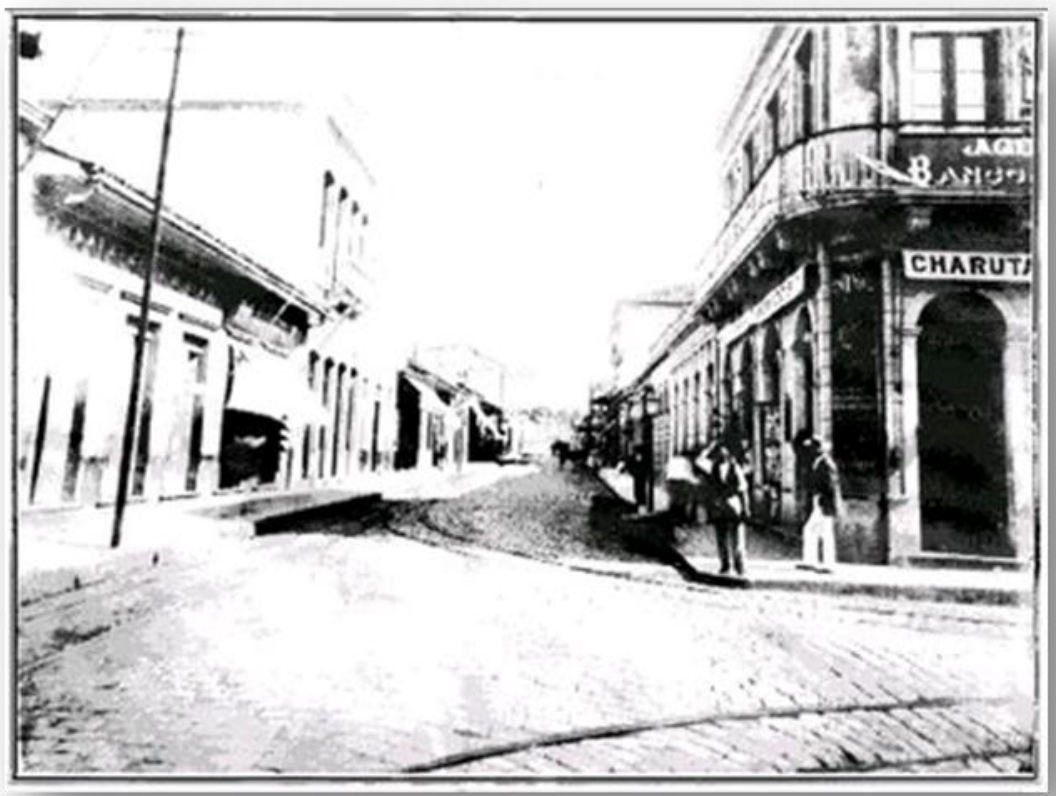

RUA BARÃO DE JAGUARA EM 1901. 


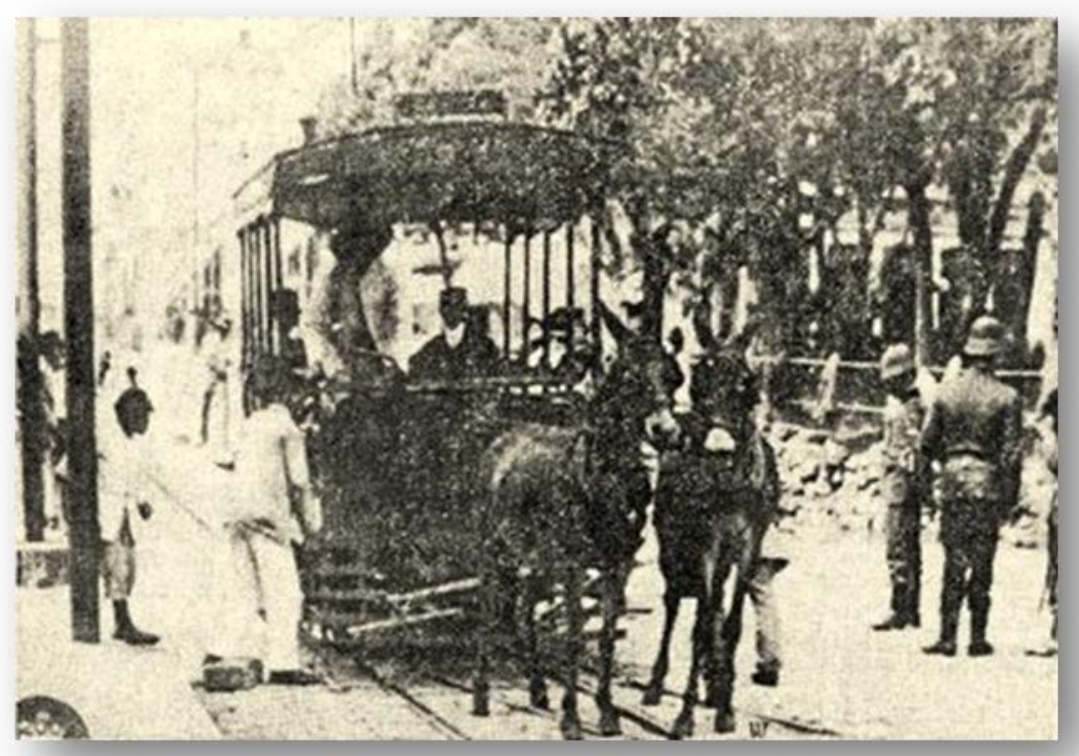

RUA BARÃO DE JAGUARÁ EM 1900.

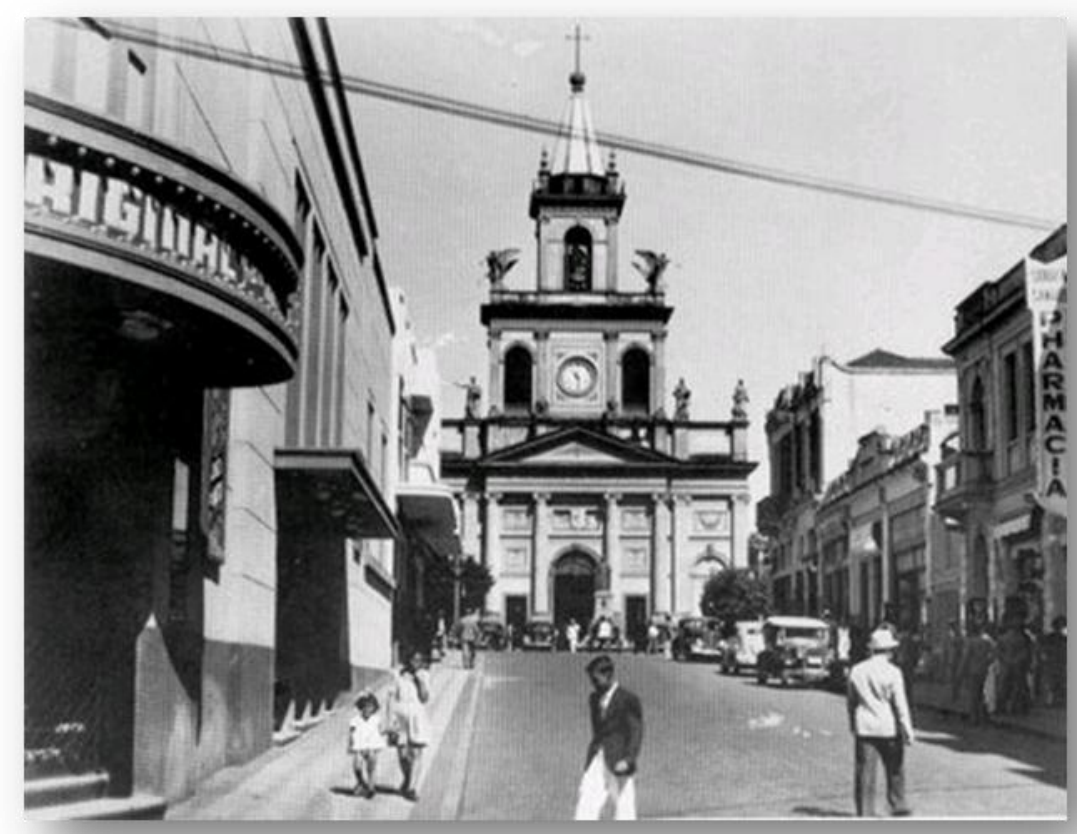

RUA CONCEIÇÃO EM 1940. 


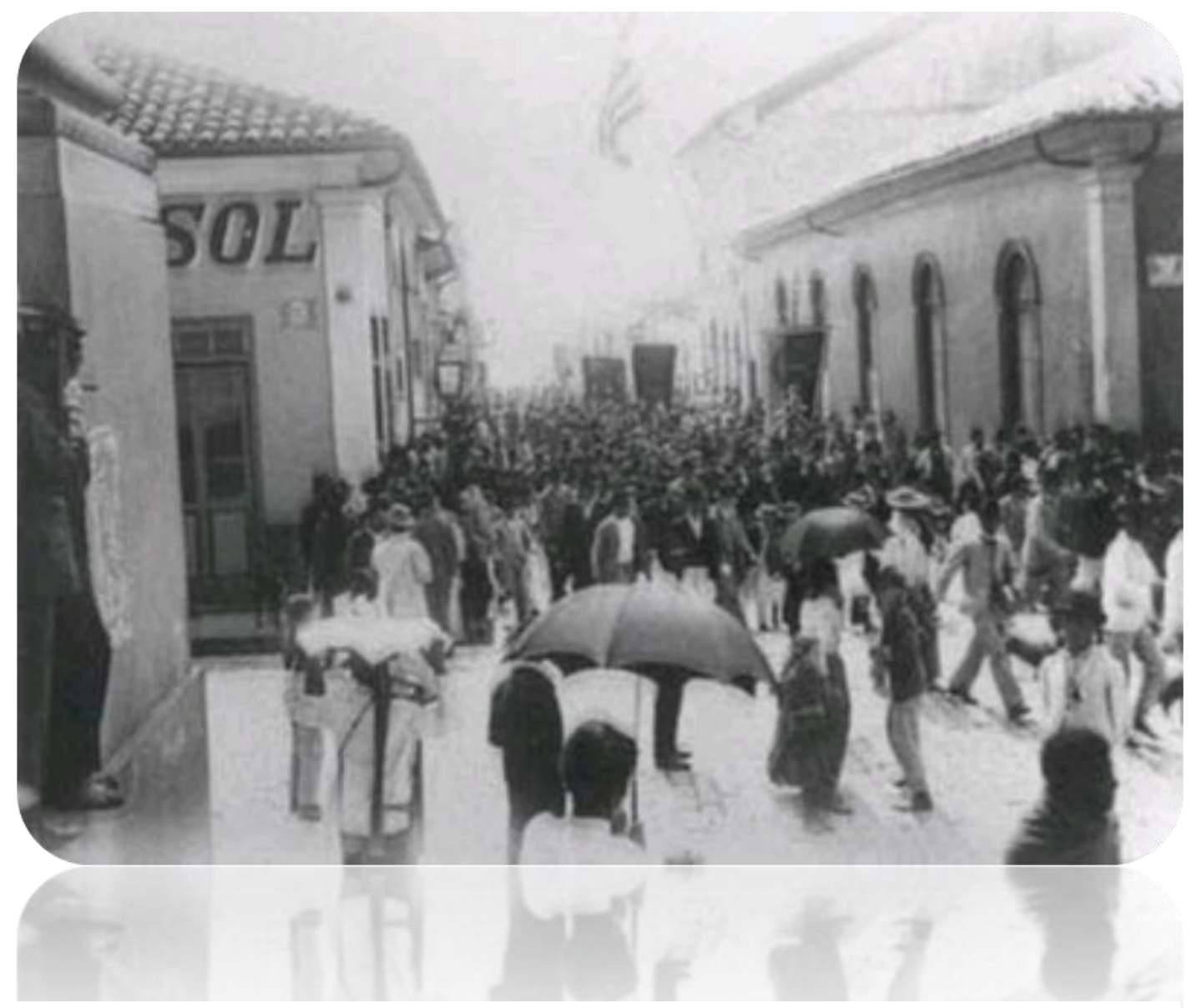

RUA TREZE DE MAIO EM 1903. 


\section{FONTES}

Relatórios de presidente de provincia de São Paulo entre 1886 e 1916.

Processos de contravenção de vadiagem do tribunal de justiça de Campinas (TJC)

Processos de contravencão de embriaguez do TJC (1888-1918).

Processos criminais de defloramento do TJC (1888-1918).

Processos criminais de estupro do TJC (1888-1918).

Processo criminais de rapto do TJC (1888-1918).

Processos crimnais de furto do TJC (1888-1918).

Jornal a Gazeta de Campinas.

Jornal a Cidade de Campinas.

Jornal Diário de Campinas.

Jornal o Getulino, orgam para defesa do interesse dos homens de cor (1923-1926). 


\section{BIBLIOGRAFIA}

ABRAHÃO, Fernando. “O ajustar das contas, uma análise dos discursos sobre o sistema carcerário em Campinas na virada do século XX”. Disponível em www.centrodememoria.unicamp.br, acessado em jun.2010.

ABREU, M. C. "Meninas Perdidas": Os Populares e O Cotidiano do Amor No Rio de Janeiro da Bellè Epóque. Rio de Janeiro: Paz e Terra, 1989.

ALBUQUERQUE, W. R. de. Algazarra nas ruas: comemorações da independência na Bahia (1889-1923). Campinas: Editora da Unicamp, 1999.

ALVES, M. C. Quando falha o controle: crimes de escravos contra senhores (18401870), Dissertação (Mestrado em História Social), FFLCH, USP, 2010.

AMANCIO, K. A. de O. "Pela penna e pela palavra": Um Estudo sobre racismo, relações raciais e Imprensa Negra na Campinas das Primeiras décadas do século XX Monografia de fim de curso (Bacharelado em História), IFCH, UNICAMP, Campinas, 2006 .

ANASSI, V. P. Vivenciando uma Cidade em Transformação: Cotidiano de classes populares no centro de Florianópolis (1900-1920). (TCC) UFSC, Florianópolis, 2009.

ANDREWS, G. R.. Negros e Brancos em São Paulo: 1888 - 1988. Bauru, Edusc, 1998.

AZEVEDO, C. M. Onda Negra, Medo Branco: o negro no imaginário das elites século XIX.. Rio de Janeiro,Paz e Terra, 1987.

AZEVEDO, Elciene. Orfeu de Carapinha: a trajetória de Luiz Gama na imperial cidade de São Paulo. Campinas, Editora da UNICAMP, 1999.

AZEVEDO, Paulo César de, e LISSOVSKY, Maurício. Escravos brasileiros do século 
XIX na fotografia de Christiano Jr. (1864-1866) [et ali.]. São Paulo, Ex. Libris, 1988. BAENINGER, Rosana. Espaço e tempo em Campinas Migrantes e a expansão do pólo industrial paulista. Campinas, Area de publicações Centro de Memória UNICAMP, Campinas, 1996.

BALABAN, Marcelo. Poeta do Lápis: A trajetória de Angelo Agostini no Brasil Imperial - São Paulo e Rio de Janeiro - 1864-1888. Tese (Doutorado em Históra), IFCH, UNICAMP, Campinas, 2005.

BASTIDE, Roger. A Imprensa Negra no Estado de São Paulo. In: Estudos Afro-brasileiros. São Paulo: Perspectiva, 1973.

CARVAlHO, Edmir de. Habitação Popular em Campinas. Dissertação (Mestrado em História), IFCH, UNICAMP, Campinas, 1991.

CARVALHO, Marcus. De portas a dentro e de portas afora: trabalho doméstico e escravidão no recife, 1822-1850. Salvador-BA, Afro-ásia, v. 1, n. 30, p. 41-78, 2003.

SOUZA, L. A. F. de. Poder de polícia, Policía Civil e práticas policiais na cidade de São Paulo (1889-1930). Tese (Doutorado em História), FFLCH-USP, São Paulo, 1998 CHALHOUB, Sidney. Trabalho, Lar e Botequim: o cotidiano de trabalhadores no Rio de Janeiro da Belle Époque. $2^{\text {a }}$ ed. Campinas, Editora da Unicamp, 2001.

Cidade Febril. Cortiços e epidemias na corte imperial. São Paulo: Companhia das Letras, 1996.

A arte de alinhavar histórias: a série $\mathrm{A}+\mathrm{B}$ de Machado de Assis. In: CHALHOUB, Sidney; PEREIRA, Leonardo Affonso de Miranda; NEVES, Margarida de Souza. (Org.). História em cousas miúdas: capítulos de história social da crônica no Brasil. 1 ed. Campinas, Editora da UNICAMP, 2005. v. , p. 67-85.

CUNHA, O. G. \& GOMES, F. dos S. Quase-cidadão: histórias e antropologias da pósemancipação no Brasil. Rio de Janeiro: Editora FGV, 2007. 
DEAN, Warren. Rio Claro, um Sistema Brasileiro de Grande Lavoura 1820-1920. Rio de Janeiro, Paz e Terra, 1977.

DE QUEIRÓZ, M. I. P. Coletividades negras. Ascensão sócio-econômica dos negros no Brasil e em São Paulo. Ciência e Cultura, São Paulo, v. 29, nº6, jun.1977.

DIAS, M. O. L. da S. Quotidiano e Poder em São Paulo no século XIX. 2a ed. São Paulo: Brasiliense, 1995.

DOMINGUES, Petrônio. Uma história não contada: negro, racismo e branqueamento em São Paulo no pós-abolição. São Paulo: Editora SENAC, 2004.

FRANCO, M. S. C.: Homens livres na ordem escravocrata. São Paulo, IEB, 1969.

FERNANDES, Florestan. A integração do negro na sociedade de classes. 2 vol. São Paulo, Companhia Editora Nacional, 1965.

FERRARA, M. N. A Imprensa Negra Paulista (1915-1963). 1981. 205fls. Dissertação (Mestrado em Antropologia), FFLCH-USP: 1981.

FERRAZ, L. M. Testamentos, Alforrias e Liberdade: Campinas, século XIX. Monografia (Bacharel em História), IFCH, UNICAMP, 2006.

FONER, Eric. Nada além da liberdade: a emancipação e seu legado. Rio de Janeiro, Paz e terra, 1988.

FRAGA FILHO, Walter. Mendigos moleques e Vadios na Bahia do Século XIX, São Paulo, HUCITEC/EDUFBa, 1996

. Encruzilhadas da liberdade: histórias de escravos e libertos na Bahia (18701910), Campinas, Editora da UNICAMP, 2007.

GARZONI, L. de C. Vagabundas e conhecidas: novos olhares sobre a polícia republicana (Rio de Janeiro, início do século XX), Dissertação (Mestrado em História), IFCH, UNICAMP, Campinas, 2007.

GINZBURG, Carlo. O queijo e os vermes: o cotidiano e as idéias de um moleiro 
perseguido pela inquisição. $3^{\mathrm{a}}$ ed. São Paulo, Companhia das Letras, 2005.

GLEDSON, John. Machado de Assis Ficção e história. Rio de Janeiro, Paz e Terra, 1986.

KOSSOY, Boris, e CARNEIRO, M. L. T, O olhar europeu: o negro na iconografia brasileira do Século XIX,. São Paulo, Edusp, 1994.

LAPA, J. R. do A. . A cidade: Os Cantos e os Antros. Campinas 1850-1900. São Paulo, EDUSP, 1996.

LARA, S. H. "Blowin in the Wind - E.P Thompson e a experiência negra no Brasil", Projeto História. São Paulo. Revista do Programa de Estudos Pós-Graduados em História e do Departamento de História PUC-SP. n 12. p.47, outubro de 1995, Escravidão, Cidadania e História do Trabalho no Brasil. Projeto História, São Paulo, v.16, pp. 25-38, 1998.

MACIEL, C. da S. Discriminações Raciais - negros em Campinas 1888-1926. $2^{\mathrm{a}}$ ed. Campinas, Área de publicações/Centro de Memória da UNICAMP, 1997.

MACHADO, M. H. P. T. Crime e escravidão: Trabalho, Luta, Resistência nas lavouras paulistas, 1830-1888. São Paulo: Editora Brasiliense, 1988.

MACHADO, M. H. de T. O plano e o pânico, os movimentos sociais na década da abolição. Rio de Janeiro, Editora UFRJ; São Paulo: Editora da USP, 1994.

MARTINS, R. L. M. Os caminhos da liberdade - Abolicionista, escravos e senhores na Província do Espírito Santo (1884-1888). Campinas, Área de Publicações/Centro de Memória Unicamp, 2005.

MARTINS, Valter. Policiais e populares: educadores, educandos e a higiene social. Campinas, Cad. CEDES, vol.23, nº.59, abr. 2003.

MATTOS, H M. Ao Sul da História: lavradores pobres na crise do trabalho escravo. São Paulo: Brasiliense, 1987. 
. "Laços de família e direitos no final da escravidão". In: ALENCASTRO, Luiz

Felipe de (Org.) História da vida privada no Brasil. Vol 2. Império: a corte e a modernidade nacional. Coleção dirigida por Fernando Novais. São Paulo: Companhia das Letras, 1997.

MENDONÇA, Joseli. Entre a mão e os anéis: a lei dos sexagenários e os caminhos da abolição no Brasil. Campinas, Editora Unicamp: 1999.

MIRANDA, Cristiany. Gerações da Senzala: famílias e estratégias escravas no contexto dos tráficos africano e interno. Campinas, século XIX. Tese (Doutorado em História), IFCH, UNICAMP, Campinas, 2004.

MIRANDA, Rodrigo. Um caminho de suor e letras: a militância negra em Campinas e a construção de uma comunidade imaginada nas páginas do Getulino (Campinas, 19231926). Tese (Doutorado em História), IFCH, UNICAMP, 2005.

NOMELINI, P. C. B. Associações operárias mutualistas e recreativas em Campinas (1906-1930). Dissertação (Mestrado em História), Campinas, IFCH, UNICAMP, 2007. OLIVEIRA, A. C. de. Quem é a "Gente Negra Nacional"? Frente Negra Brasileira e a Voz da Raça, 1933-1937. 2006. Tese (Doutorado em História), IFCH-UNICAMP, Campinas, 2006.

PIRES, F. N., Fios da Vida. Tráfico interprovincial e alforrias nos Sertoins de SimaBahia, 1860-1929. São Paulo, Annablume/FAPESP, 2009.

PIROLA, R. F. A conspiração escrava de Campinas, 1832: Dissertação (Mestrado em História), IFCH, UNICAMP, 2005.

RIOS, A. L. \& MATTOS, H. M. Memórias do Cativeiro: Família, trabalho e cidadania no pós-abolição. Rio de Janeiro, Civilização Brasileira, 2005.

ROSEMBERG, A. Polícia, policiamento e o policial na província de São Paulo no final do império: a instituição, prática cotidiana e cultura. Tese (Doutorado em História 
Social); São Paulo, FFLCH, USP, 2008.

SANTIAGO, Silvana, Tal Conceição, Conceição de Tal. Classe, gênero e raça no cotidiano de mulheres pobres no Rio de Janeiro das primeiras décadas republicana. Dissertação (Mestrado em História), IFCH, UNICAMP, Campinas, 2007.

SANTOS FILHO, L. de C. A febre amarela em Campinas: 1889 -1900. Campinas, Área de Publicações/ Centro de Memória Unicamp, 1996.

SCHWARCZ, L. K. M. Retrato em branco e negro: jornais, escravos e cidadãos em São Paulo no final do século XIX. São Paulo, Companhia das Letras, 1987.

SCOTT, Rebeca. Emancipação Escrava em Cuba: a transição para o trabalho livre (1860-1899). Rio de Janeiro, Paz e Terra, Editora da Unicamp, Campinas, 1991.

SLENES, R. W. A. Malungu ngoma vem! África coberta e descoberta no Brasil. Revista da USP, São Paulo, n. 12, 1991-1992, p. 12-67. Senhores e Subalternos no Oeste Paulista. In História da vida privada no Brasil. Vol.2, pp. 233.290.

Na Senzala uma flor: esperanças e recordações na formação da família escrava - Brasil Sudeste, século XIX. Rio de Janeiro, Editora Nova Fronteira, 1999. TÍEDE, L. M. Imprensa Negra e espaços de sociabilidade em São Paulo no início do século XX. Monografia de fim de curso (Bacharelado em História). IFCH, UNICAMP, Campinas, 2003.

Sob suspeita, negros, pretos e homens de cor em São Paulo no início do século XX. Dissertação (Mestrado em História), IFCH, UNICAMP, Campinas, 2006. THOMPSON, E. P. Senhores e Caçadores. Rio de Janeiro, Paz e Terra, 1987. Costumes em Comum. São Paulo, Companhia das Letras, 1988. 
XAVIER, R. C. L. A Conquista da Liberdade: Libertos em Campinas na segunda metade do século XIX. Campinas, Área de publicações/Centro de Memória UNICAMP, 1996.

. "Dos males e suas curas". In: CHALHOUB, Sidney; MARQUES, Regina Beltrão; SAMPAIO, Gabriela dos Reis; SOBRINHO, Carlos Roberto Galvão. (Org.). As artes e ofícios de curar no Brasil: capítulos de história social. Campinas, Editora da Unicamp, 2003.

WEIMER, R. de A. Os nomes da liberdade: experiências de autonomia e práticas de nomeação em um município da serra rio-grandense nas duas últimas décadas do século XIX. Dissertação (Mestrado em História), UFRGS, Porto Alegre, 2007. 